\title{
Closing the loop - Approaches to monitoring the state of the Arctic Mediterranean during the International Polar Year 2007-2008
}

\author{
C. Mauritzen ${ }^{\mathrm{a}, *}$, E. Hansen ${ }^{\mathrm{b}}$, M. Andersson ${ }^{\mathrm{c}}$, B. Berx ${ }^{\mathrm{d}}$, A. Beszczynska-Möller ${ }^{\mathrm{e}}$, I. Burud ${ }^{\mathrm{a}}$, K.H. Christensen ${ }^{\mathrm{a}}$, \\ J. Debernard $^{\text {a }}$, L. de Steur ${ }^{\mathrm{b}}$, P. Dodd ${ }^{\mathrm{b}}$, S. Gerland ${ }^{\mathrm{b}}$, Ø. Godøy ${ }^{\mathrm{a}}$, B. Hansen ${ }^{\mathrm{f}}$, S. Hudson ${ }^{\mathrm{b}}$, F. Høydalsvik $^{\mathrm{a}}$, \\ R. Ingvaldsen ${ }^{g}$, P.E. Isachsen ${ }^{\text {a }}$, Y. Kasajima ${ }^{c}$, I. Koszalka ${ }^{\text {h }}$, K.M. Kovacs ${ }^{\text {b }}$, M. Køltzow ${ }^{\text {a }}$, J. LaCasce ${ }^{\text {h }}$, C.M. Lee ${ }^{\mathrm{i}}$,

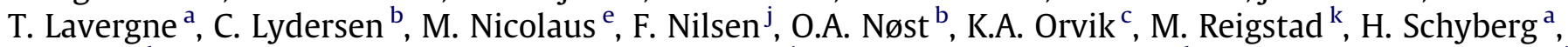 \\ L. Seuthe ${ }^{\mathrm{k}}$, Ø. Skagseth $^{\mathrm{g}}$, J. Skarðhamar ${ }^{\mathrm{g}}$, R. Skogseth ${ }^{\mathrm{j}}$, A. Sperrevik ${ }^{\text {a }}$, C. Svensen ${ }^{ }$, H. Søiland ${ }^{\mathrm{g}}$, S.H. Teigen ${ }^{\mathrm{j}}$, \\ V. Tverberg ${ }^{g}, C$. Wexels Riser ${ }^{k}$
}

${ }^{a}$ Norwegian Meteorological Institute, P.O. Box 43 Blindern, 0313 Oslo, Norway

${ }^{\mathrm{b}}$ Norwegian Polar Institute, Polar Environmental Centre, 9296 Tromsø, Norway

${ }^{\mathrm{C}}$ Geophysical Institute, University of Bergen, P.O. Box 7803, 5020 Bergen, Norway

${ }^{\mathrm{d}}$ Marine Scotland Science, Aberdeen, 375 Victoria Road, AB11 9DB, UK

e Alfred Wegener Institute for Polar and Marine Research, P.O. Box 1201 61, 27515 Bremerhaven, Germany

${ }^{\mathrm{f}}$ Faroes Marine Research Institute, P.O. Box 3051, FO-110 Tórshavn, Faroe Islands

${ }^{\mathrm{g}}$ Institute of Marine Research, P.O. Box 1870 Nordnes, 5817 Bergen, Norway

${ }^{\mathrm{h}}$ Department of Geosciences, University of Oslo, P.O. Box 1047 Blindern, 0316 Oslo, Norway

${ }^{i}$ Applied Physics Laboratory, University of Washington, 1013 NE 40th Street, Box 355640, Seattle, WA 98105-6698, USA

${ }^{\mathrm{j}}$ The University Centre in Svalbard (UNIS), P.O. Box 156, 9171 Longyearbyen, Norway

${ }^{\mathrm{k}}$ Department of Arctic and Marine Biology, University of Tromsø, 9037 Tromsø, Norway

\section{A R T I C L E I N F O}

Article history:

Available online 24 February 2011

\begin{abstract}
A B S T R A C T
During the 4th International Polar Year 2007-2009 (IPY), it has become increasingly obvious that we need to prepare for a new era in the Arctic. IPY occurred during the time of the largest retreat of Arctic sea ice since satellite observations started in 1979. This minimum in September sea ice coverage was accompanied by other signs of a changing Arctic, including the unexpectedly rapid transpolar drift of the Tara schooner, a general thinning of Arctic sea ice and a double-dip minimum of the Arctic Oscillation at the end of 2009. Thanks to the lucky timing of the IPY, those recent phenomena are well documented as they have been scrutinized by the international research community, taking advantage of the dedicated observing systems that were deployed during IPY. However, understanding changes in the Arctic System likely requires monitoring over decades, not years. Many IPY projects have contributed to the pilot phase of a future, sustained, observing system for the Arctic. We now know that many of the technical challenges can be overcome.

The Norwegian projects iAOOS-Norway, POLEWARD and MEOP were significant ocean monitoring/ research contributions during the IPY. A large variety of techniques were used in these programs, ranging from oceanographic cruises to animal-borne platforms, autonomous gliders, helicopter surveys, surface drifters and current meter arrays. Our research approach was interdisciplinary from the outset, merging ocean dynamics, hydrography, biology, sea ice studies, as well as forecasting. The datasets are tremendously rich, and they will surely yield numerous findings in the years to come. Here, we present a status report at the end of the official period for IPY. Highlights of the research include: a quantification of the Meridional Overturning Circulation in the Nordic Seas ("the loop") in thermal space, based on a set of up to 15-year-long series of current measurements; a detailed map of the surface circulation as well as characterization of eddy dispersion based on drifter data; transport monitoring of Atlantic Water using gliders; a view of the water mass exchanges in the Norwegian Atlantic Current from both Eulerian and Lagrangian data; an integrated physical-biological view of the ice-influenced ecosystem in the East Greenland Current, showing for instance nutrient-limited primary production as a consequence of decreasing ice cover for larger regions of the Arctic Ocean. Our sea ice studies show that the albedo of snow on ice is lower when snow cover is thinner and suggest that reductions in sea ice thickness, without
\end{abstract}

\footnotetext{
* Corresponding author. Tel.: +47 2296 3345; fax: +47 22963050.

E-mail address: c.mauritzen@met.no (C. Mauritzen).
} 
changes in sea ice extent, will have a significant impact on the arctic atmosphere. We present up-to-date freshwater transport numbers for the East Greenland Current in the Fram Strait, as well as the first map of the annual cycle of freshwater layer thickness in the East Greenland Current along the east coast of Greenland, from data obtained by CTDs mounted on seals that traveled back and forth across the Nordic Seas. We have taken advantage of the real-time transmission of some of these platforms and demonstrate the use of ice-tethered profilers in validating satellite products of sea ice motion, as well as the use of Seagliders in validating ocean forecasts, and we present a sea ice drift product - significantly improved both in space and time - for use in operational ice-forecasting applications.

We consider real-time acquisition of data from the ocean interior to be a vital component of a sustained Arctic Ocean Observing System, and we conclude by presenting an outline for an observing system for the European sector of the Arctic Ocean.

(c) 2011 Elsevier Ltd. All rights reserved.

\section{Introduction}

iAOOS (integrated Arctic Ocean Observing System) is a researchbased step toward creating a sustainable ocean observing system in the Arctic. This initiative is led by the Arctic Ocean Sciences Board. It attempts to coordinate and optimize ongoing observation efforts at high latitudes in the North.

iAOOS-Norway: Closing the loop is the Norwegian contribution to iAOOS, funded by the Norwegian Research Council for the years 2007-2010. It aims to coordinate, modernize, and utilize ongoing Norwegian monitoring of the Arctic Mediterranean (the Arctic Ocean and the Barents, Greenland, Iceland and Norwegian Seas). Our main objective is to contribute to a modern operational observing system for the Arctic, with particular emphasis on meeting society's needs for knowledge and information about, and safety in, the High North. We have performed process studies (biospheric, oceanographic and cryospheric), maintained and improved long-term monitoring sites, and tried to reduce the temporal lag between obtaining new research results and applying them in operational public services providing forecasts of arctic conditions.

"The loop" refers to the large-scale ocean circulation that transports warm water poleward from the equator. In the Atlantic, this circulation is primarily a vertical overturning structure (thus, it is commonly referred to as the "Meridional Overturning Circulation", the MOC). In the Nordic Seas and the Arctic Ocean, on the other hand, the circulation becomes more of a horizontal loop: warm waters flow northward in the east, and cold, dense waters flow towards the Atlantic in the west. The loop is at its narrowest in the Nordic Seas and broadens out in the Arctic. Norwegian contributions to monitoring this system will naturally be focused primarily on the Nordic Seas, thus our project subtitle is "closing the loop".

In this paper, we touch upon a broad range of activities carried out and results obtained in iAOOS-Norway, and in the simultaneous Norwegian IPY projects POLEWARD (surface drifters) and MEOP (animal-borne platforms). To serve the purpose of providing an overview of the state of the Nordic Seas, we also include many contributions from outside these three projects, this being reflected in the long list of authors. The paper is arranged as follows: in Section 2 we provide an overview of the methods and tools used; in Section 3 we discuss "the loop", its forcing mechanisms, its strength, its structure and its hydrographic properties; in Section 4 we present sensitivity and process studies of sea ice; in Section 5 we use the contrasting Arctic and Atlantic biological regimes to investigate possible ecosystem changes in a warming climate. In Section 6, we show how IPY data are used to improve operational ocean and ice forecasts through improving data products, model validation and data assimilation. The paper ends with a discussion of ocean observation systems in Section 7. Note that iAOOS-Norway and the other IPY projects are still in progress and that not all results are published yet. We therefore list in Table A1 the contact information of the investigators responsible for the individual research topics.

\section{Methods}

\subsection{Tools}

The iAOOS-Norway sampling region covers both open ocean and ice-covered seas. It covers the in- and outflows of the Arctic Ocean as defined by the boundary currents of the region: the Norwegian Atlantic Current (splitting into the West Spitsbergen Current and the Barents Sea inflow), and the East Greenland Current (Fig. 1). Information about key state variables of the boundary currents has been collected using both conventional methods (moored instruments yielding high-resolution time series of temperature, salinity and velocity) and new observing techniques, such as gliders and moored profiling instruments. We have combined in situ observations and remote sensing. During cruises, we have sampled biological and physical data using conventional observing techniques (e.g. nets, Conductivity-Temperature-Depth instruments (CTDs), Acoustic Doppler Current Profiler (ADCP)). In addition to the oceanographic measurements, manned meteorological stations on arctic islands were used for observations of atmospheric parameters relevant for the air-sea interaction studies within the project. Existing instrumentation was augmented with sensors observing atmospheric broadband radiance, a central parameter for calibration and validation of remote sensing products.

\subsection{Data management}

All data collected within iAOOS-Norway are to be stored in a publicly available data repository. Data are formatted according to NetCDF/CF with some additional global attributes that are required for proper data discovery. Metadata and the actual datasets are available through http://dokipy.met.no/, which contains a discovery interface along with a data repository served by Thematic Realtime Environmental Distributed Data Services (THREDDS, see http://www.unidata.ucar.edu/projects/THREDDS/). This data server provides HTTP and OpeNDAP access to the data sets and the discovery interface provides metadata describing the datasets along with a Uniform Resource Indicator (link) to the actual dataset. All metadata are freely available. In addition to the interactive interface, metadata access is also facilitated through an Open Archives Initiative Protocol for Metadata Harvesting (OAI-PMH), which supports GCMD DIF. This interface is currently being updated to fully support the International Polar Year metadata profile. Access to the actual datasets may (for some datasets) require authentication and authorization during the quality assessment phase of the data handling process.

\subsection{Sections and sampling sites}

In the following paragraphs, we list the tools applied and observations made under iAOOS-Norway to "close the loop". We do this section by section, starting with the inflowing Atlantic water and 


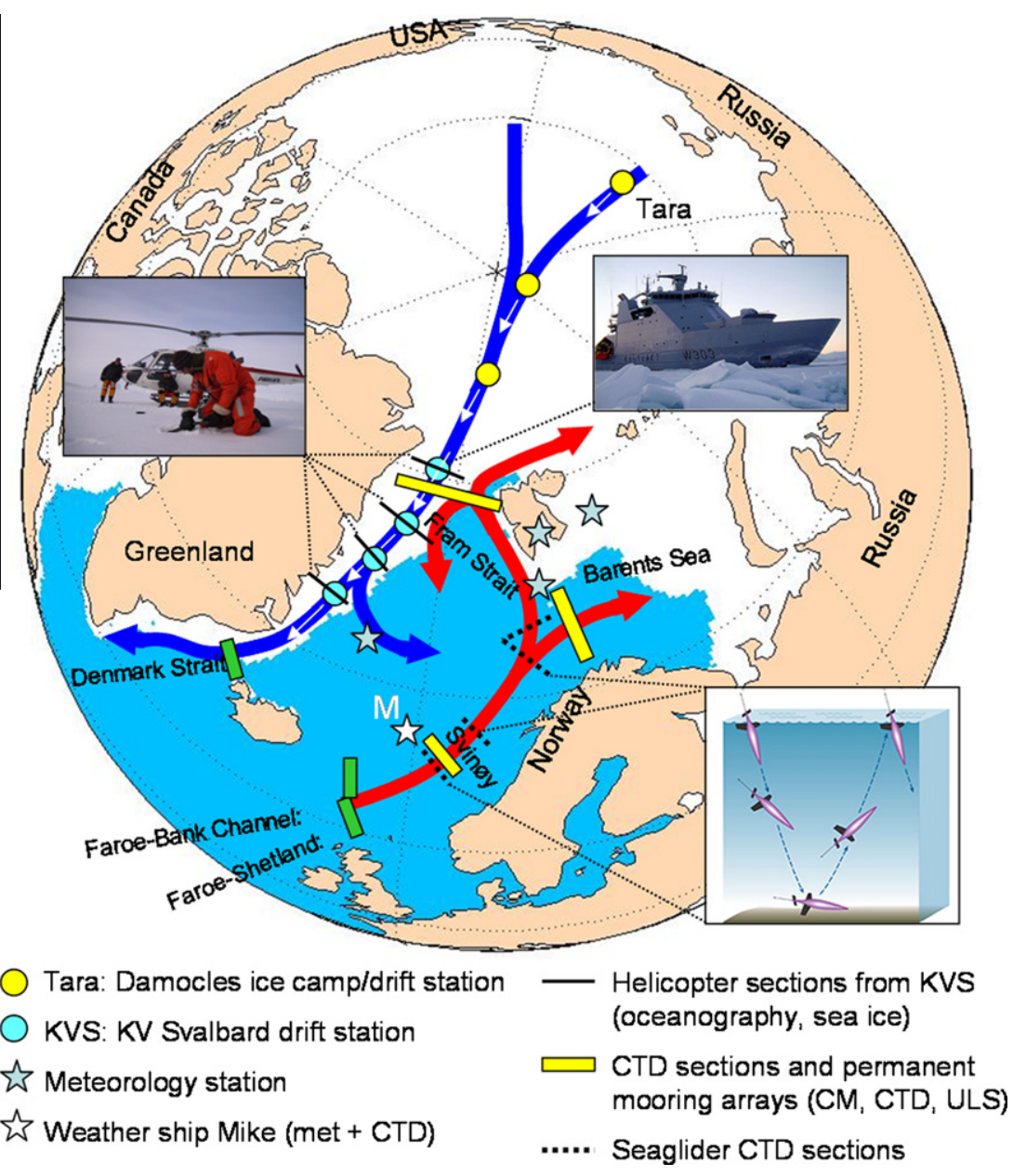

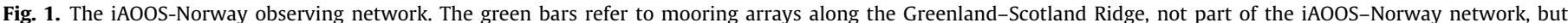
referred to in the text.

ending with the outflowing East Greenland Current. The sections, cruises and instrument deployments are illustrated in Fig. 1.

\subsubsection{The Svinøy Section}

With its S1 master mooring in position $62^{\circ} 49.4 \mathrm{~N} 4^{\circ} 17.5 \mathrm{E}$ at $500 \mathrm{~m}$ depth, the Svinøy Section has provided a continuous time series since 1995 in the core of the eastern branch of the Norwegian Atlantic Current (NAC). During iAOOS-Norway, we have tested the feasibility of monitoring the western branch as well, through use of Seagliders (Eriksen et al., 2001). The gliders have been operated successfully in the section nine times, yielding new information about the structure and strength of the outer branch of the current at Svinøy (see Sections 3.3 and 6.2).

\subsubsection{The Fugløya - Bear Island Section}

This section contains a current meter array that captures the Atlantic Water flow into the Barents Sea after a bifurcation of the slope branch of the NAC. Current meter data have been collected here since 1997 and hydrographic transects have been conducted since the mid-1960s. During iAOOS, we have made additional efforts to capture the Norwegian Coastal Current (Skagseth et al., 2011) and to quantify the recirculation of Atlantic Water in the Bear Island Trough (Skagseth, 2008). Additional current meter moorings have been deployed along the continental margin of the Barents Sea Opening, and Webb gliders have been surveying the Barents Sea Opening.
2.3.3. The Fram Strait East Section in the West Spitsbergen Current

This site in the West Spitsbergen Current (WSC) has been operated with standard current meter moorings by the Alfred Wegener Institute since the mid-1990s. iAOOS-Norway has supplemented the array with an ADCP mooring at the shelf edge, to better capture the lateral on-shelf eddy exchange and heat loss.

\subsubsection{Tara and drifting ice station instrumentation}

An integrative study of atmosphere, snow, sea ice, and ocean processes was performed during the drift of the schooner Tara (Fig. 1). Tara was frozen into the ice north of the Laptev Sea $\left(79.5^{\circ} \mathrm{N}, 143^{\circ} \mathrm{E}\right)$ on September 4,2006 and left the ice in Fram Strait after 505 drifting days on January 21, 2008 (Gascard et al., 2008), emulating the Fram expedition of 1893-1896. The main fieldwork program was performed from April to September 2007, covering the most interesting times of late winter, melt onset, melt pond formation and development, and autumn freeze-up. Atmospheric conditions and broadband radiation (Vihma et al., 2008), spectral albedo and transmissivity (Nicolaus et al., 2010b) were monitored continuously. Snow and sea-ice properties were monitored weekly along defined transects, with the aid of snow pits and ice cores.

\subsubsection{The Fram Strait West Section in the East Greenland Current}

This site in the East Greenland Current (EGC) at $78^{\circ} 50 \mathrm{~N}$ has been maintained by the Norwegian Polar Institute since 1997, with an improved, more closely spaced mooring set-up since 2002. It features six moorings covering the EGC and the outer fringe of 
the East Greenland Shelf. The iAOOS-Norway project allowed us to augment the instrumentation in this section and secure the time series through IPY and into the post-IPY period. The mooring array features current meters, temperature-conductivity sensors, upward looking sonars that observe ice thickness and ADCPs that document sea ice drift and upper layer transports. During iAOOSNorway, the focus of the observations in this region has been on freshwater outflow and water mass properties.

\subsection{6. iAOOS-Norway cruises}

Two cruises were carried out specifically for iAOOS-Norway with the coastguard vessel KV Svalbard, in April 2007 (3 weeks) and April-June 2008 ( 7 weeks). The cruises took place in western Fram Strait over the EGC (Fig. 2). Because of the location, these sites actually provided "late winter" data for the physical oceanographers as part of their efforts to resolve the seasonal variability of the EGC (CTD, ADCP and bottle (tracer) data), as well as "wintertime" sea ice data and late winter/spring marine biology data. The observations were made from the ship, on the ice and by helicopter. The helicopter was used to extend the range of the observations, carrying scientists with portable equipment out from the ship. It was also used to make high-resolution transects of sea ice thickness using electromagnetic techniques (EM bird), across the Transpolar Drift where sea ice exits the Arctic Ocean through the Fram Strait.

In addition three cruises with $R / V$ Lance in September 2007, 2008 and 2009 provided CTD, ADCP and bottle data (tracers) from the same region in Fram Strait (Fig. 3). During these cruises the mooring array across the EGC was serviced.

\subsubsection{Seal-borne data-loggers}

CTD data along the East Greenland Current south of the Fram Strait was provided by the IPY project MEOP-Norway (www.meop.info/en/index.html). This project deployed 20 CTD tags (CTDSRDLs) on hooded seals (Cystophora cristata) in the West Ice, north of Jan Mayen (three in 2007, seventeen in 2008). The data enabled us to track the water masses of the EGC as it leaves the Arctic Ocean through the Fram Strait and onward towards the Denmark Strait (see Section 3.7).

\section{The loop}

Ocean circulation in the Nordic Seas and the Arctic Ocean is dominated by the large-scale MOC. The Norwegian Atlantic Current carries warm water northwards in the Nordic Seas whereafter dense overflows across the Greenland-Scotland Ridge return it to the North Atlantic. The northernmost limb of this overturning circulation extends throughout the Arctic Ocean itself.

The MOC is made possible by the large north-south temperature gradient imposed by solar forcing, by the large scale wind fields, and by the fact that internal mixing eventually allows the
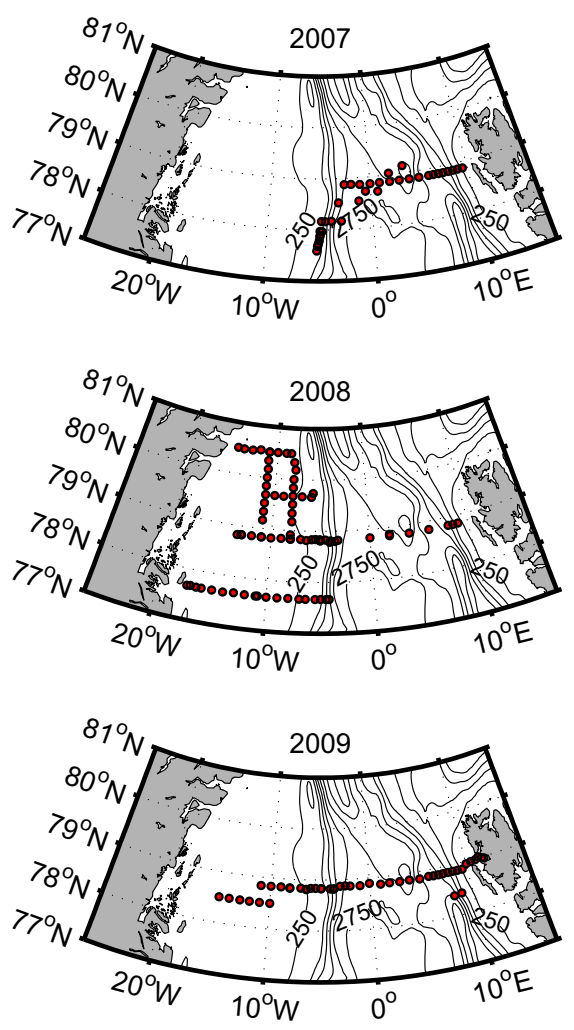

Fig. 3. Cruise tracks for RV Lance in the Fram Strait in 2007 (top), 2008 (middle) and 2009 (bottom).

dense waters to transform back to lighter and shallower water masses (Wunsch, 2002).

We can differentiate between the steady and the variable parts of the MOC. Idealized models, in which a stratified ocean is subjected to a large-scale north-south temperature gradient, exhibit a surface circulation which broadly resembles that in the North Atlantic, with an eastward flow impinging on the eastern boundary and turning north in a narrowing current along the eastern boundary (Pedlosky, 1969; Salmon, 1986; Marotzke, 1997; LaCasce, 2004). The warm waters cool in the north and mix vertically, eventually returning southward along the western boundary. The constancy of the flow in such models follows from the forcing; despite seasonal variations in the heating, a large-scale surface temperature gradient exists year round.

In the idealized models, only temperature is taken into account, and densification occurs as a consequence of parameterized mixing. In reality, the densification process is more complicated. First, cooling must overcome the freshening that occurs due to mixing with less saline waters along the northward path. The Arctic Ocean
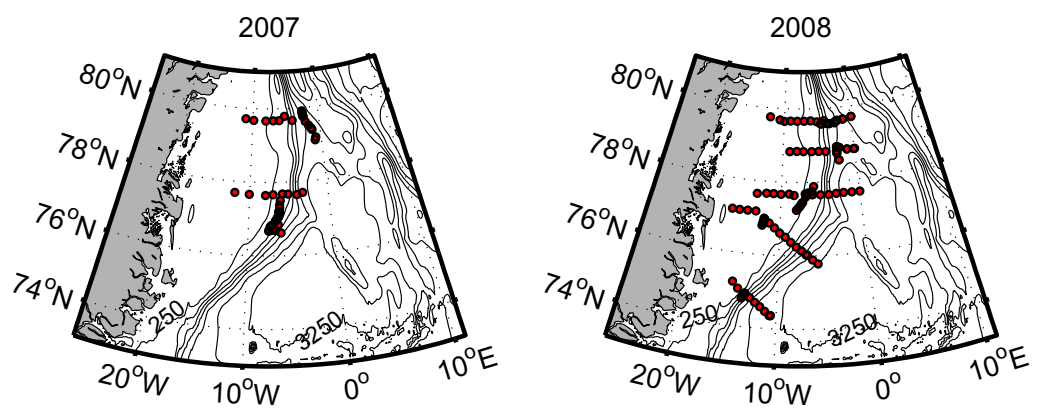

Fig. 2. Cruise tracks for KV Svalbard in the Fram Strait in 2007 (left) and 2008 (right). 
is large source of freshwater, which influences the MOC further (Aagaard and Carmack, 1989; Mauritzen, 1996a). Additionally, the cooling process is likely mediated by eddies, which advect heat laterally and increase the surface area of the current which is in contact with the cooler atmosphere. The cooled Atlantic Water (AW) in the Norwegian Atlantic Current then subducts below the fresher surface water in the Arctic Ocean. Isolated from direct contact with the atmosphere, the AW circles the Arctic Ocean and exits at depth in the East Greenland Current. This cooled AW is a major source of the deep overflow water from the Nordic Seas back to the North Atlantic Ocean (Mauritzen, 1996b; Isachsen et al., 2007). Thus, the water mass transformations occurring in the Norwegian Atlantic Current (NAC) play a major role in determining the characteristics of the overflow water feeding the global MOC.

The idealized models also exhibit an NAC with a single core, adjacent to the eastern boundary. However, surface drifter observations in the Nordic Seas suggest that the NAC has two distinct branches, one over the continental slope and a second offshore branch near the $1500 \mathrm{~m}$ isobath (Poulain et al., 1996; Orvik and Niiler, 2002). This splitting is apparently caused by topography, which is neglected in the aforementioned models. Taking topography into account, Nøst and Isachsen (2003) reproduced a two-core structure in a flow field reconstructed from hydrography. The inner branch enters the Nordic Seas via the Faroe-Scotland Ridge, while the outer branch enters west of the Faroes.

The magnitude of the time-varying part of the MOC is much less than that of the steady part. For instance, velocity point measurements in the Norwegian Atlantic Current ay Svinøy (Orvik and Skagseth, 2005) indicate that the amplitude of the seasonal cycle is roughly $25 \%$ of the mean. This variability in the NAC is strongly correlated with the wind (Orvik and Skagseth, 2003; Skagseth et al., 2004; Olsen et al., 2008; Richter et al., 2009). The largest seasonal signal is, however, found within the closed geostrophic contours of the Greenland, Norwegian and Lofoten Basins. This circulation is primarily barotropic in nature and driven by wind (Isachsen et al., 2003).

The lateral eddy mixing noted above also contributes to temporal variability near the NAC. These eddies are deformation scale (5$10 \mathrm{~km}$ ) and are surface-intensified (e.g. LaCasce, 2005). They likely result from the baroclinic instability of the inflow; similar features are seen in idealized models (Spall, 2005). The eddies are responsible for the short predictability time scale in the region (1-2 days).

In addition to increasing the surface area in contact with the atmosphere, eddy advection greatly increases the time required for fluid parcels to transit from the Iceland-Scotland ridge to Spitsbergen. Thus, it also increases the time during which the surface waters are cooled, by increasing the residence time of Atlantic Water in the Nordic Seas. The Lofoten Basin appears to store AW for a particularly long time. Drifter experiments indicate a residence time for AW of 1-3 years (Gascard and Mork, 2008) in the Lofoten Basin, and the Atlantic Water layer is up to $200 \mathrm{~m}$ thicker there than in the rest of the Atlantic domain (Orvik, 2004; Rossby et al., 2009), implying that the Atlantic Water spends more time there than further south along the path. However, even in the swift slope branch of the NAC, the propagation of anomalies is an order of magnitude slower than the actual current speed (e.g. $3.6 \mathrm{~cm} / \mathrm{s}$ northward from the Svinøy Section; Furevik, 2001).

\subsection{Quantifying the loop}

Many of the openings and narrow sections of "the loop" have been monitored for extended periods, thanks to the persistence of many scientists and programs, such as VEINS (Variability of Exchanges in the Northern Seas) and ASOF (Arctic-Subarctic Ocean Fluxes). We can therefore present an overview of the long-term (meaning in several cases near decade-long) average volume fluxes for "the loop" in the Nordic Seas (see Fig. 4 and Table A2). The individual sections will be discussed in detail below. To emphasize the transformations the loop current is exposed to, we present these results as a function of temperature classes. Ideally, we would have liked to do so in salinity classes as well, but the quality of the data is not sufficient for that purpose. It is therefore the thermal transformations (the cooling), not the haline transformations (the freshening), of the MOC that will be the focus in this section.

At the entrance to the Nordic Seas, the warm Atlantic Water enters primarily west and east of the Faroes (the third branch, between Iceland and Greenland, transports slightly less than $1 \mathrm{~Sv}$ $\left(10^{6} \mathrm{~m}^{3} / \mathrm{s}\right)$ of Atlantic Water (Jónsson and Briem, 2003)). The western branch has been monitored since 1997 north of the Faroes, i.e. at a site just inside the Norwegian Sea. The average volume transport for $1997-2001$ of waters warmer than $4{ }^{\circ} \mathrm{C}$ is $4 \mathrm{~Sv}$, and the main temperature mode is in the range $7-7.5^{\circ} \mathrm{C}$ (Fig. 4b). The eastern branch, in the Faroe-Shetland Channel, has been monitored since 1994. The average transport for $1994-2008$ is $4 \mathrm{~Sv}$. This branch contains only water warmer than $8^{\circ} \mathrm{C}$, and the main mode temperature range is $9.5-10^{\circ} \mathrm{C}$ (Fig. 4a). During the more than 15 years of monitoring in the Faroe-Shetland Channel, there has been no apparent long-term change in the inflow. Since the temperature modes of these two branches are so different, it is likely that they represent two rather distinct inflows, even though the western branch is suspected to a detour into the Faroe-Shetland Channel before entering the Norwegian Sea proper.

At Svinøy, the long-term average volume flux for the eastern branch is estimated to be $5.2 \mathrm{~Sv}$ ( $4.2 \mathrm{~Sv}$ warmer than $5{ }^{\circ} \mathrm{C}$ ), with the main temperature mode in the range $8.5-9{ }^{\circ} \mathrm{C}$ (Fig. 4c). Interestingly, the outer branch, as monitored by nine Seaglider transects between January and September 2009 (see Section 3.3), transports more water than the inner branch. It transports $6.4 \mathrm{~Sv}$ in temperature classes warmer than $5^{\circ} \mathrm{C}$, the main temperature mode being in the range $7-8{ }^{\circ} \mathrm{C}$ (Fig. 4d). The total transport at Svinøy for water warmer than $5^{\circ} \mathrm{C}$ is thus $10.6 \mathrm{~Sv}$ (but keep in mind that the western end has only been monitored for less than a year).

The volume transport at the Barents Sea opening is $1.6 \mathrm{~Sv}$ for waters warmer than $4{ }^{\circ} \mathrm{C}$, the main temperature mode being in the range $6-6.5{ }^{\circ} \mathrm{C}$ (Fig. 4e). The net northward transport in the Fram Strait (primarily in the West Spitsbergen Current) is $3.2 \mathrm{~Sv}$, all warmer than $2{ }^{\circ} \mathrm{C}$ (Fig. 4f). The main temperature mode is in the range $3-3.5^{\circ} \mathrm{C}$. The total transport of "warm" water exiting the Norwegian Sea (to the Barents Sea and to the Arctic Ocean) is thus $5.8 \mathrm{~Sv}$.

Overall, these results show that there must be significant entrainment $(\mathrm{O}(2-3 \mathrm{~Sv}))$ into the current between the IcelandScotland Ridge and Svinøy, especially if the Seaglider data turn out to be representative of a longer-time average. Similarly, there must be significant detrainment $(\mathrm{O}(5 \mathrm{~Sv}))$ from the current into the Nordic Sea interior and into the East Greenland Current between Svinøy and the Fram Strait.

The net southward transport of cold water from the Arctic to the Nordic Seas in the Fram Strait (primarily in the East Greenland Current) is $5.2 \mathrm{~Sv}$. All of this water is colder than $2{ }^{\circ} \mathrm{C}$, the main temperature mode of the EGC being the range from -1 to $-0.5^{\circ} \mathrm{C}$ (Fig. 4f).

The export of cold, dense water from the Nordic Seas to the North Atlantic occurs both east and west of Iceland. In the Denmark Strait, west of Iceland, Dickson et al. (2008) estimate the long-term dense water export to be $4 \mathrm{~Sv}$ (all colder than $2{ }^{\circ} \mathrm{C}$; no further separation in temperature classes was provided), whereas in the Faroe Bank Channel there is export in all temperature classes colder than $7^{\circ} \mathrm{C}$ (totaling $2.2 \mathrm{~Sv}$ ). However, the main mode is colder than $0{ }^{\circ} \mathrm{C}$ : $1.2 \mathrm{~Sv}$.

The water mass transformations within the loop alter the median temperature from $7-10^{\circ} \mathrm{C}$ at the entrance to the Nordic Seas 
near the Faroes, to $6-6.5^{\circ} \mathrm{C}$ at the Barents Sea opening, to $3-3.5^{\circ} \mathrm{C}$ as the water enters the Arctic in the Fram Strait, and down to less than $2{ }^{\circ} \mathrm{C}$ as it exits the Nordic Seas across the Greenland-Scotland Ridge east and west of Iceland (Figs. 4 and 5). The overall magnitude of the loop $(\mathrm{O}(8 \mathrm{~Sv})$ of warm water entering the Nordic Seas; $\mathrm{O}(6 \mathrm{~Sv})$ of dense water returning to the North Atlantic) is consistent with estimates dating as far back as Worthington (1969; also see Mauritzen, 1996b), and supports the basic idea that this loop is a consequence of the more or less steady north-south temperature difference of the northern hemisphere.

\subsection{Moving through the loop: monitoring the Atlantic Water convergence zone in the southern Norwegian Sea with floats}

RAFOS floats deployed at intermediate depth $(\sim 800 \mathrm{~m})$ on the slope north of the Faroes show a remarkable degree of topographic steering (Søiland et al., 2008) (Fig. 6a). On the other hand, RAFOS floats deployed shallower, in the Atlantic Water at 200-250 m, on the Iceland-Faroe Ridge are much less steered by the topography (Rossby et al., 2009) (Fig. 6b). Nearly all (16 out of 17) shallow floats that entered the southern Norwegian Sea north of the Faroes,

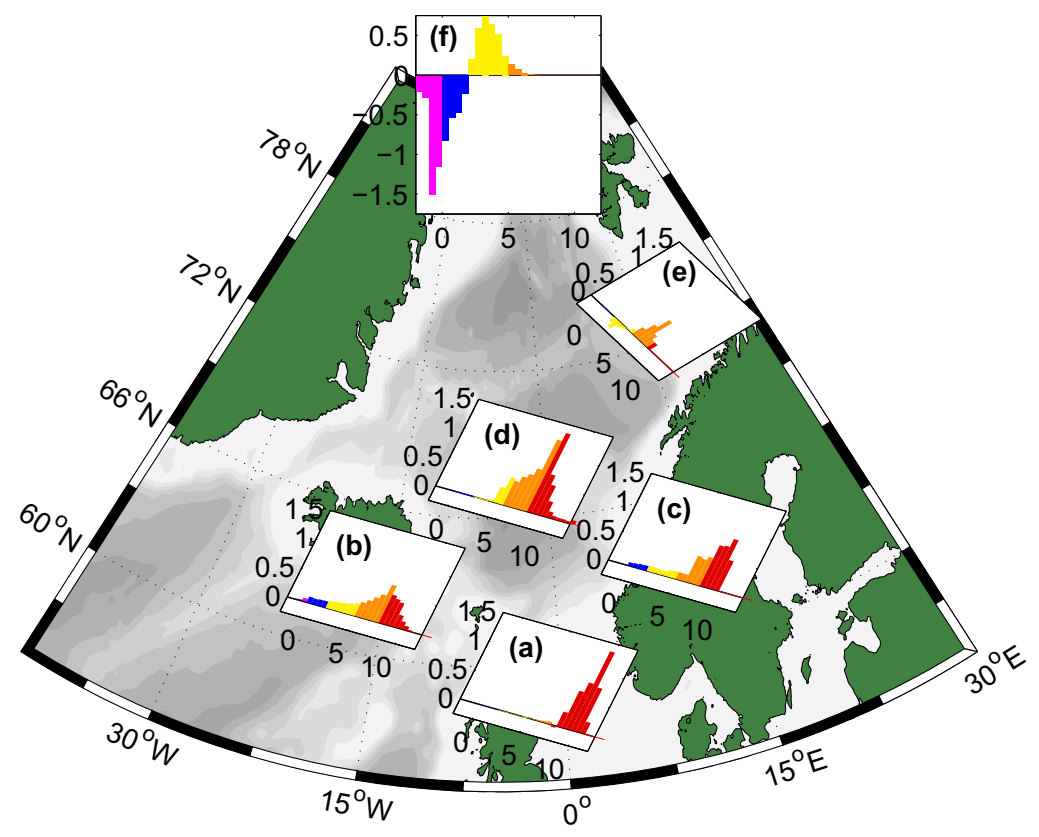

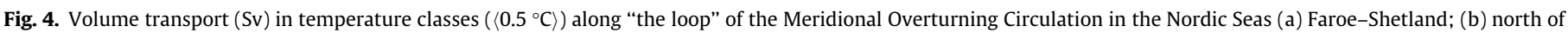

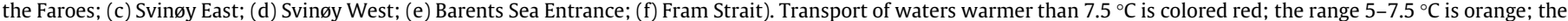
range $2-5{ }^{\circ} \mathrm{C}$ is yellow; the range $0-2{ }^{\circ} \mathrm{C}$ is blue; and transport colder than $0{ }^{\circ} \mathrm{C}$ is purple. See more information about the individual sections in Table A2.
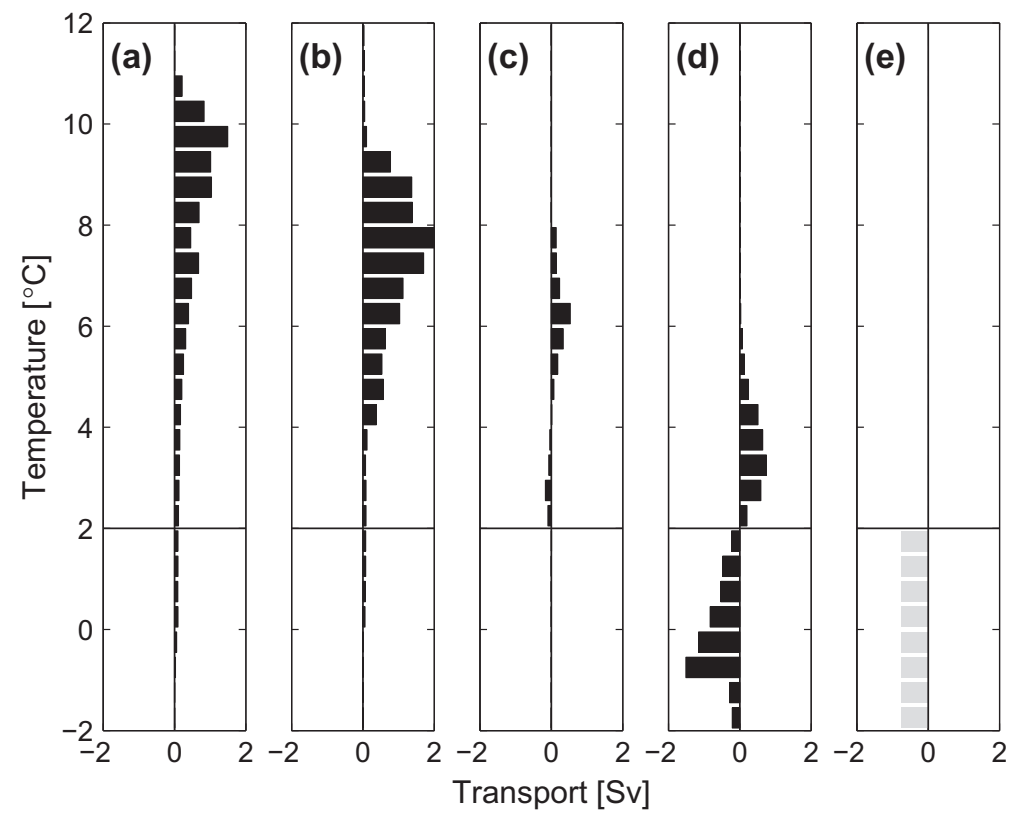

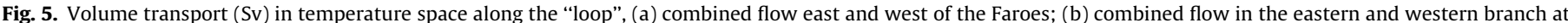

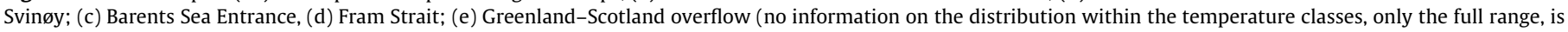
given). See Table A2 for more information. 

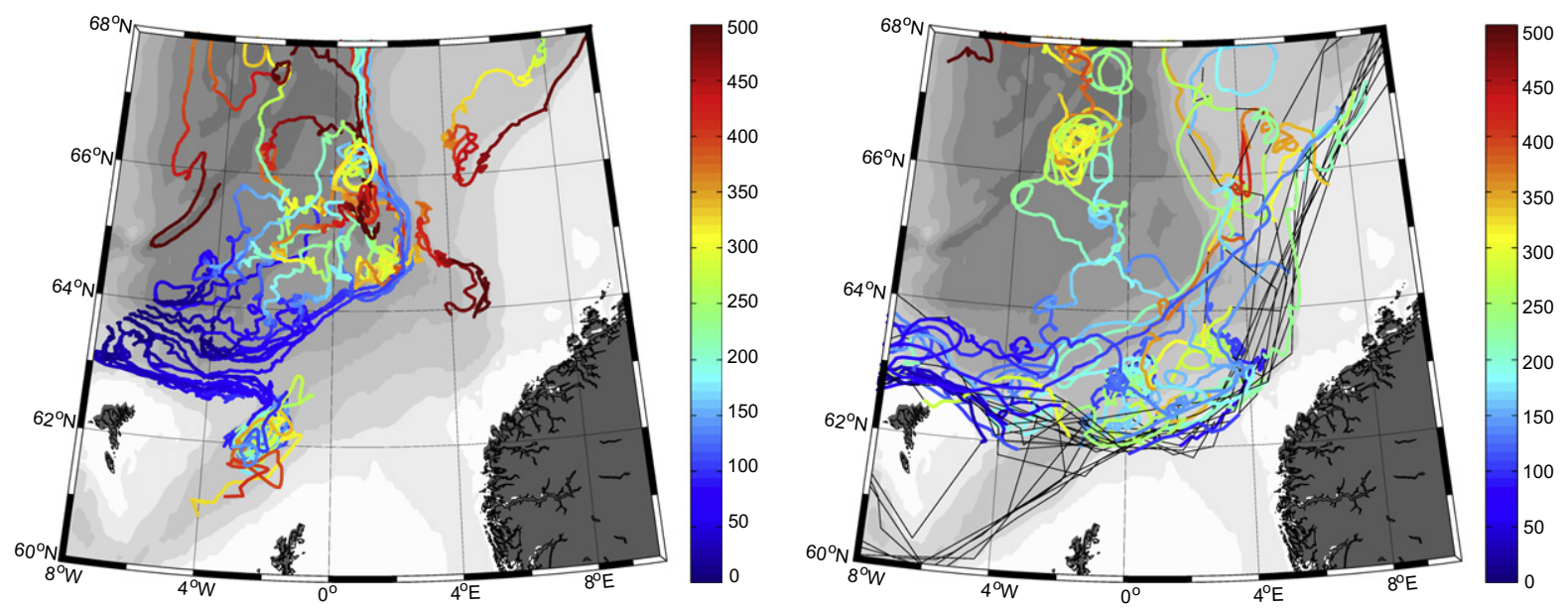

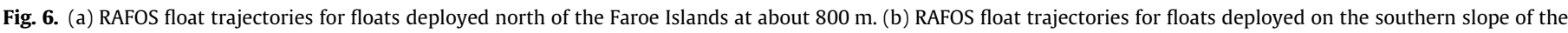
Island -Faroe Ridge in the depth range $200-250 \mathrm{~m}$. Thin black lines indicate missing position data. Color code indicates days since deployment.

were at some point located on the inner branch, and most of these floats (11) continued north-eastward towards the Lofoten Basin along the shelf break. In general, there is significant exchange between the outer and inner branches, supporting the idea of strong eddy mixing in the region. Thus, the two branches are not distinct in a Lagrangian sense (Rossby et al., 2009). This we already hypothesized based on hydrographic analysis (Section 3) and it is also confirmed by data from the surface drifters further north (Section 3.4).

\subsection{Moving through the loop: the Norwegian Atlantic Current at Svinøy measured by conventional bottom-anchored current meters and by autonomous Seagliders}

During IPY, we have reached the milestone of a 15-year current and temperature time series in the Svinøy east array (Fig. 4c). The current observations reveal a dominant seasonal signal with a winter maximum superimposed on interannual variability throughout the observing period (Fig. 7). A striking maximum of the annual flow was reached during 2005-2006 (preceding the Arctic sea ice extent minimum in 2007). The average temperature has risen by almost $1{ }^{\circ} \mathrm{C}$ from 1995 to 2008 , but it was at its absolute maximum in 2003 (Fig. 7). The 2003 warming event has been connected to dynamical processes in the northern North Atlantic, particularly the slowdown of the Subpolar gyre in the Labrador Sea (Hátún et al., 2005).

Generally, the observations at Svinøy demonstrate independence between the flow field and temperature field: the flow field dominates the heat-flux variability on a yearly timescale, while temperature variations contribute on longer time scales (Orvik and Skagseth, 2005). Comparisons between Sea Surface Height (SSH) observations from satellite altimeter data in the North Atlantic and temperature and velocity measurements from moorings in the Svinøy Section confirm that temperature variations appear to be independent of the flow field. By resolving the SSH-field using Empiric Orthogonal Functions (EOF) methodology, it is shown that the temperature variability coincides with the first EOF mode with a correlation coefficient of 0.82 , while the velocity field mirrors the second EOF mode, explaining $15 \%$ of the variance, with a correlation coefficient of 0.74 (Orvik and Skagseth, 2010).

The current meter array at Svinøy does not extend north-westward far enough to capture all the warm Atlantic Water crossing the Svinøy Section (the Svinøy East Section only covers the isobaths between $200 \mathrm{~m}$ and $1000 \mathrm{~m}$ ). Therefore during iAOOS-Norway we have extended the Svinøy line out to the $3000 \mathrm{~m}$ isobath using Seagliders (Fig. 8; Eriksen et al., 2001; see also http:// www.apl.washington.edu/projects/seaglider/summary.html).

Between January and September 2009 the Seaglider SG160 made nine transects along the Svinøy West Section (Figs. 4d and 8). Analysis of the data reveals a prominent deep-water current in the temperature range $-1{ }^{\circ} \mathrm{C}$ to $1{ }^{\circ} \mathrm{C}$ in addition to the warm current (Fig. 9). This deep-water current boosts the volume transport of Atlantic Water by adding a significant reference velocity to the geostrophic shear. The absolute mean flux of Atlantic Water (Figs. 9 and 10 ) in the outer branch was estimated to be roughly $6.4 \mathrm{~Sv}$, where about $50 \%$ of the transport was determined by the large implicit reference velocity to the baroclinic shear. Since this deeper flow is not accounted for in previous estimates (Mork and Blindheim, 2000; Orvik et al., 2001), these results (despite the short time span) justify revisitation of the total volume flux of Atlantic Water at Svinøy.

There is variability in the velocity and total transport between the transects, whereas the distribution of transport in temperature space is in general more persistent; the warm current is characterized by a large tail on the colder side and a shorter tail on the warmer side of the main temperature mode, which lies between 7.5 and $8^{\circ} \mathrm{C}$ (Fig. 10a). The accumulated transport of waters that are truly of Atlantic origin (warmer than $7-8^{\circ} \mathrm{C}$ ) is $\sim 3 \mathrm{~Sv}$ (Fig. 10b).

The near-real-time data transmission of the Seaglider allows us to merge the Seaglider data in operational forecasting systems. This will be discussed in Section 6 .

\subsection{Moving through the loop: monitoring the Norwegian Atlantic Current with drifters}

In the POLEWARD project, Lagrangian surface drifters (drifting buoys which track the near-surface currents) were released at four sites along the pathway of the Norwegian Atlantic Current: at Svinøy, off Gimsøy, at Bear Island, and at the opening of the Barents Sea. Additional deployments were recently made in the Lofoten Basin. All in all, 148 drifters have been deployed, in June/July 2007, October 2007, March 2008, October 2008 and June/July 2009. This represents the largest single deployment of freely drifting instruments in the Nordic Seas to date. Thus, POLEWARD greatly augments the existing data set for the region (Fig. 11), most of which is derived from instruments deployed to the south. Both the new and the historical data are archived at the AOML-NOAA Global Drifter Program (http://www.aoml.noaa.gov).

We are performing various analyses on the drifter trajectories. First, we are mapping the mean surface velocities, eddy kinetic 


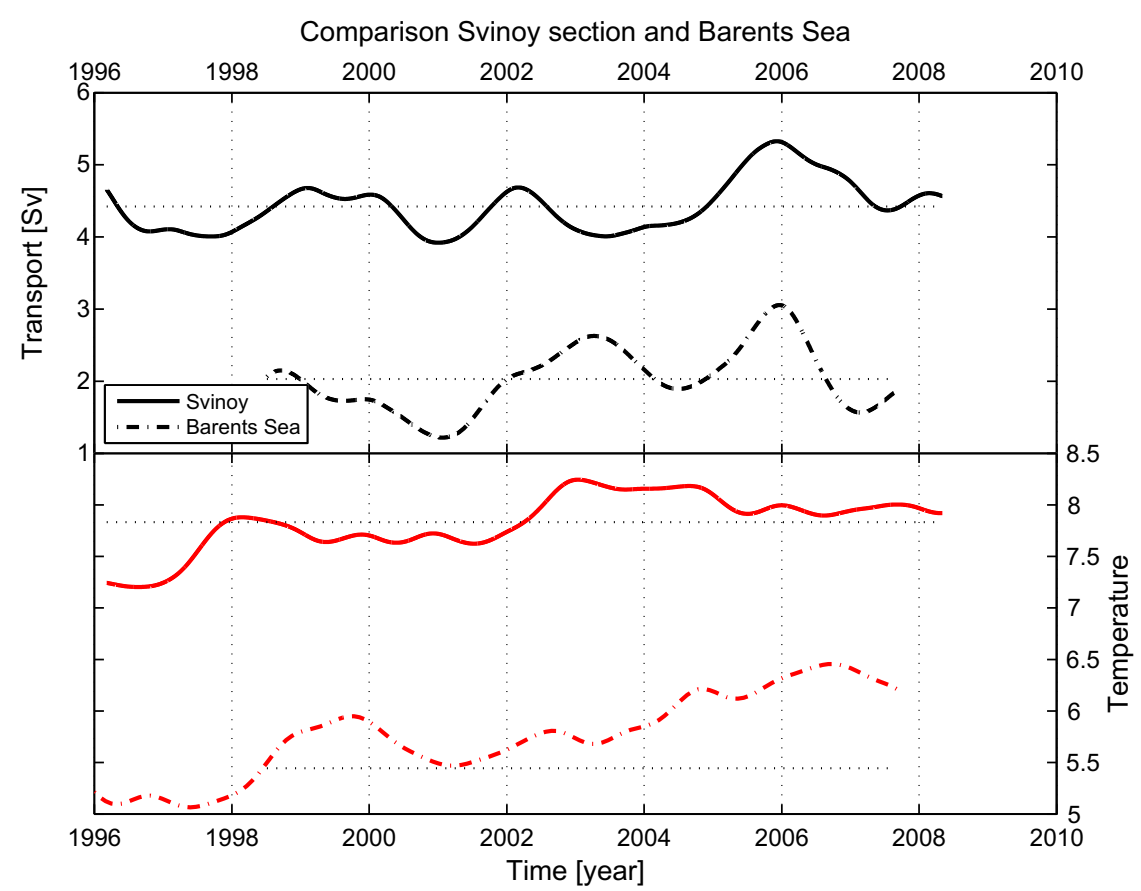

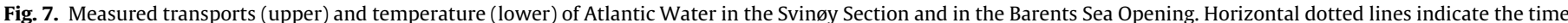

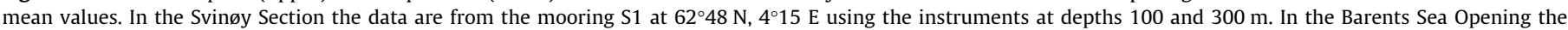

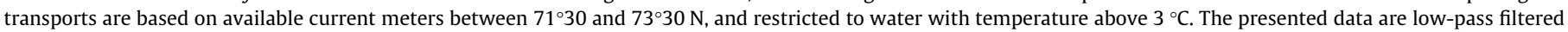
applying a Hanning window of effective length 1 year.

energies (EKEs) and diffusivities. The mean velocities and EKEs are shown in Fig. 12. The drifters reveal the two cores of the northward-flowing NAC, and show how strongly both are steered by the bottom topography. Some drifters also move onto the shelf, where they are entrained in the coastal current. The currents can be traced northward to Spitsbergen, where many of the drifters turn southward. Because the drifters are confined to the surface, they cannot track the subducting waters and must recirculate in the Nordic Seas, or else enter the Arctic at the surface.

The colors in Fig. 12 indicate the EKE. We see that the variability is greatest near the cores of the NAC, consistent with those cores generating eddies, via instability. In addition, we see that the Lofoten Basin is a region of elevated variability, suggesting that eddies are spreading into that basin. The root mean square (rms) velocities here are $\mathrm{O}(20 \mathrm{~cm} / \mathrm{s})$, comparable to the flow speeds in the NAC cores. The mean fields are detailed in Andersson et al. (submitted for publication) and in Koszalka et al. (accepted for publication).

Secondly, we are examining particle dispersion in the Nordic Seas. The POLEWARD drifters were deployed in pairs or triplets, making it possible to measure how quickly groups of drifters dispersed. The main result from this analysis is shown in Fig. 13, which shows the mean square separation of all pairs that had an initial separation of $2 \mathrm{~km}$ or less (there were 93 such pairs).

There are three dispersion regimes. At scales below $5-10 \mathrm{~km}$, the pair separations grow exponentially in time, with an e-folding time scale of about a half a day. This is indicative of Lagrangian chaos, as there is a sensitive dependence on the initial position of the particles. From $10-100 \mathrm{~km}$, the mean square separations increase as time cubed. This is known as "Richardson dispersion" and is characteristic of turbulent flows in which the energy is moving toward larger scales. Above $100 \mathrm{~km}$, the dispersion grows linearly in time, as expected for a random walk model.

These results show how the eddy field, generated primarily by the NAC, is stirring the waters in the eastern Nordic Seas. The fact that the dispersion does not become random below the $100 \mathrm{~km}$ scale implies that there are eddies of this size - an order of magnitude larger than the deformation radius. The Richardson dispersion suggests that these large eddies may result from an "inverse cascade" of energy up from $10 \mathrm{~km}$, the deformation radius. The exponential regime below $10 \mathrm{~km}$ tells us that the energy spectrum is steep at those scales. Thus, those scales should be dynamically passive, being stirred by the larger scale eddies. This is important because the dynamics at scales below $10 \mathrm{~km}$ are often unresolved in ocean models and must be parameterized. It is also important for simulating passive tracers, such as spilled oil and plankton.

We are currently pursuing several other analyses. One of the primary goals of POLEWARD is to quantify the time fluid parcels require to make the transit from the southern Nordic Seas to the Fram Strait, where much of the northward-flowing water subducts. Thus, we are quantifying transit times and residence times in regions like the Lofoten Basin and the Barents Sea. Another important goal is to determine the heat fluxes, to see to what extent the eddies are spreading heat offshore, into regions such as the Lofoten Basin.

\subsection{Moving through the loop: bifurcation of the Norwegian Atlantic Current between North Cape and Spitsbergen}

At Tromsøflaket the NAC splits into two branches; one continues northwards to Spitsbergen along the shelf slope of the western Barents Sea, the other heads eastwards between Norway and Bear Island into the Barents Sea (see Fig. 12). The dynamics of the splitting itself are not well known, but Furevik (1998) found that the flow rates in the two branches are governed by local wind forcing or upstream changes in flow position or strength. An eastward displacement of the Atlantic Water in the southern Norwegian Sea forces a relatively larger portion of the water through the Barents Sea, as shown in model runs with both idealized (Furevik, 1998) and realistic (Zhang et al., 1998) topography. Current measurements show large temporal and spatial fluctuations in the Barents 


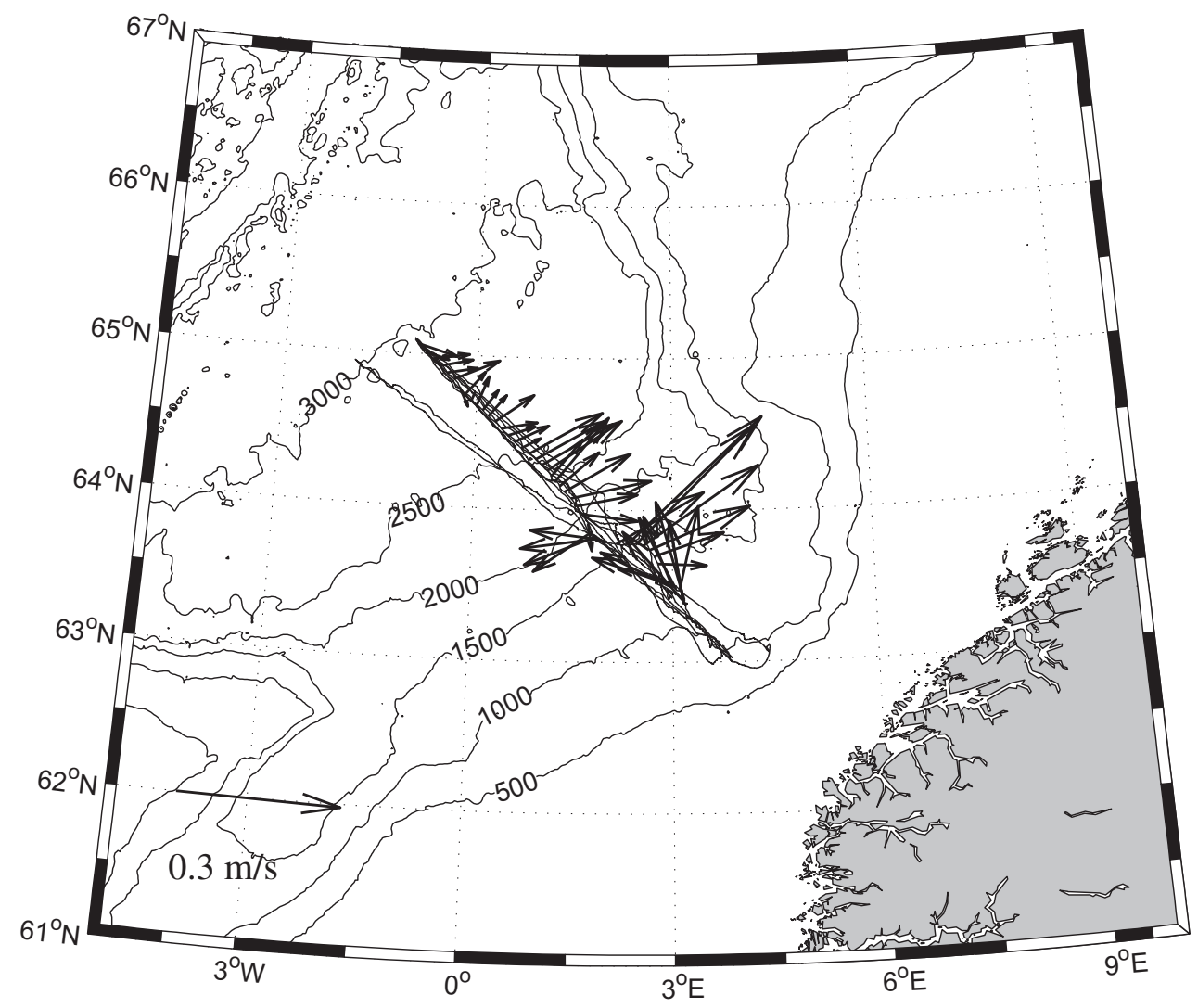

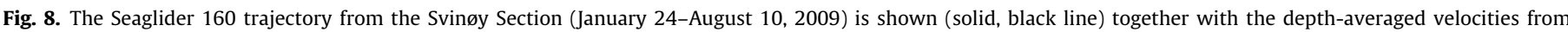

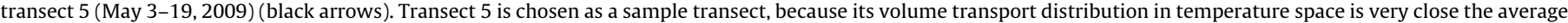
volume transport distribution for the nine transects.

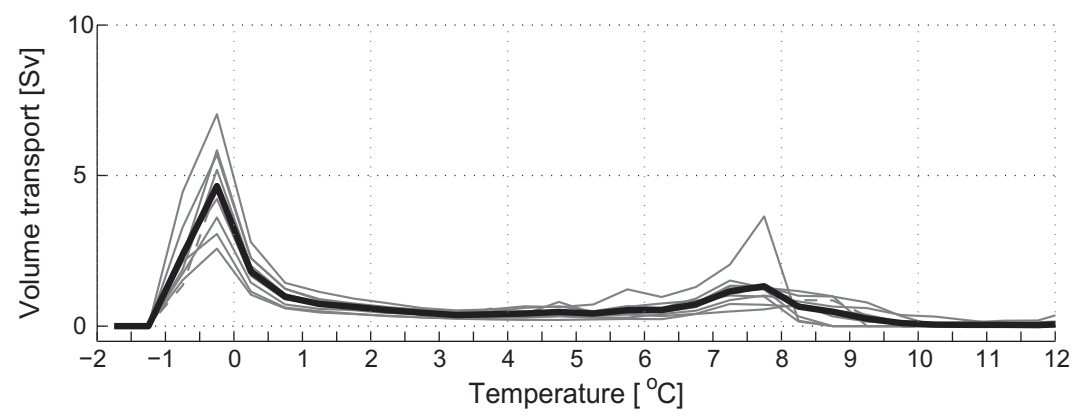

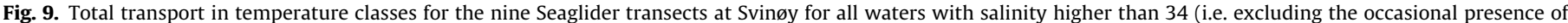

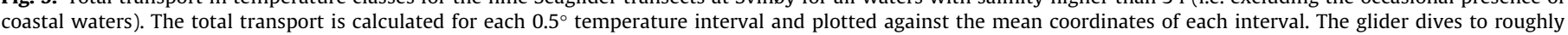
$1000 \mathrm{~m}$, thus these transport estimates correspond to the upper $1000 \mathrm{~m}$ of the water column. Individual transects are shown in gray; the average in black.

Sea inflow (Ingvaldsen et al., 2002), and this variability is strongly linked to the local wind field (Ingvaldsen et al., 2004).

Lagrangian float experiments and satellite altimetry have revealed a large-scale quasi-stationary anticyclonic eddy (50$100 \mathrm{~km}$ diameter) west of Tromsøflaket, within the inshore branch of the NAC (Gascard and Mork, 2008). Such eddy activity indicates that this region is prone to a high mesoscale turbulence activity and intense mixing between Norwegian Coastal Current and Norwegian Atlantic Current water masses. This is also demonstrated by temperature-salinity properties and anthropogenic tracer distributions (Gascard et al., 2004; Gascard and Mork, 2008). Numerical modeling experiments have reproduced similar eddies, generated by the resonance between the diurnal tidal component (K1) and the seabed slope (Kowalik and Proshutinsky, 1995; Skarðhamar and Svendsen, 2005).
The Fugløya-Bear Island Section (Fig. 4e) carries Atlantic Water into the Barents Sea in an unstable core that varies in position, width and current strength (Ingvaldsen et al., 2004). However, despite the difficulty of getting accurate estimates of the AW transport into the Barents Sea, Smedsrud et al. (2010) showed that by using updated ocean transports of heat and freshwater, the vertical mean hydrographic seasonal cycle can be reproduced fairly well. Hydrographic time series show trends in AW temperatures similar to the patterns seen in the Svinøy Section, but the volume transport does not always follow the variations seen at Svinøy (Figs. 7 and 14). The latter can be explained by the AW transport being highly dependent on regional wind patterns in the Barents Sea Opening (Ingvaldsen et al., 2004). The observations indicate that there is an oscillation in the bifurcation of the NAC at the Barents Sea Opening. The AW fluxes into the Barents Sea and the West 

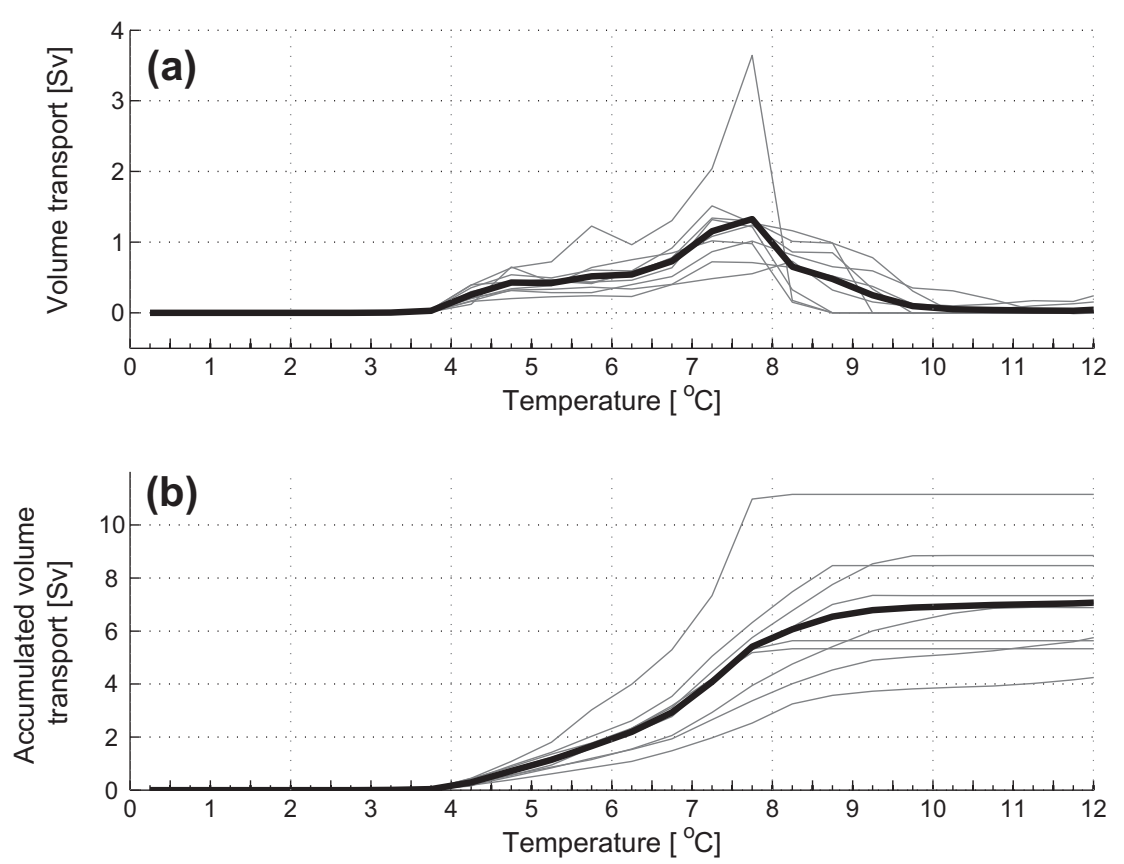

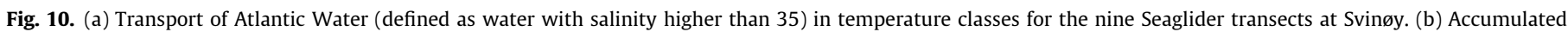
transport of Atlantic Water at Svinøy. Individual transects are shown in gray; the average in black.

\section{NO. DRIFTERS IN THE NORDIC SEAS}

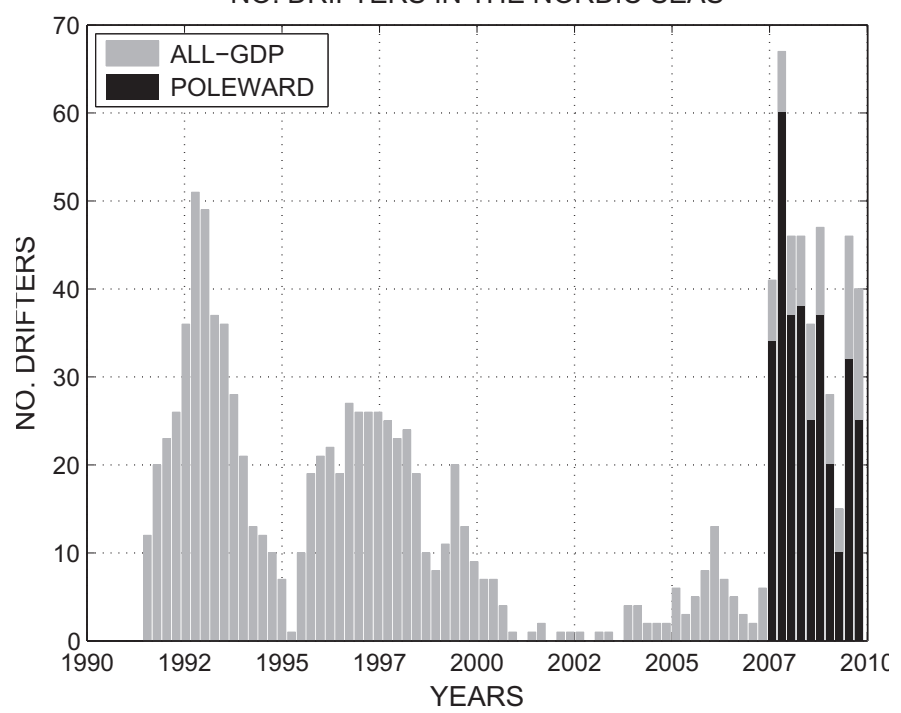

Fig. 11. The number of surface drifters in the Nordic Seas $\left(25^{\circ} \mathrm{W}-60^{\circ} \mathrm{E} ; 60^{\circ} \mathrm{N}-81^{\circ} \mathrm{N}\right)$ as available in the Global Drifter Program database (http://www.aoml.noaa.gov/ phod/dac/gdp_drifter.html) through September 2009, grouped in 90-day bins. Only drifter segments with drogue attached are included. The number of drifters corresponding to the POLEWARD deployments is marked in black. The POLEWARD contribution amounted to $90 \%$ of the total number of drifters in the Nordic Seas in May 2008.

Spitsbergen Current (WSC; the name of the NAC along Spitsbergen) are in opposite phase on scales of weeks to months as well as on inter-annual scales.

\subsection{Moving through the loop: the Fram Strait}

The Fram Strait is an extraordinarily complicated region, comprised of a $600 \mathrm{~km}$ wide gap between the Nordic Seas and the Arctic Ocean, with a sill depth of $2600 \mathrm{~m}$, with strong topographic contrasts and with equally strong horizontal current shears from the northward-flowing West Spitsbergen Current and the southward-flowing East Greenland Current. Therefore, it is crucial to monitor the entire width of the strait, as the Alfred Wegener Institute and the Norwegian Polar Institute have been doing in collaboration for about 15 years (Fig. 4f). If, for example, one only monitors the current east of $5^{\circ} \mathrm{E}$, one would find a northward transport of water warmer than $1{ }^{\circ} \mathrm{C}$ of $4.2 \mathrm{~Sv}$ for the period 2002-2008 (Fig. 15, right panel). This is in contrast to the finding for the entire strait (Figs. 4f and 15, middle panel), namely that the net northward transport was $3.2 \mathrm{~Sv}$, and warmer than $2^{\circ} \mathrm{C}$. The difference is due to the recirculation of waters within the strait itself. Similar evidence of local recirculation can be found on the western side of the strait: if one only monitors the transport west of $0^{\circ}$, one would find a total mean volume transport of $7.4 \mathrm{~Sv}$ southward in the period 2002-2008 (Fig. 15, left panel), whereas the finding for the entire strait (Figs. $4 \mathrm{f}$ and 15 , middle panel) is that the net southward transport was $5.2 \mathrm{~Sv}$, all colder than $2{ }^{\circ} \mathrm{C}$.

The cooling of the warm Atlantic Water in the WSC intensifies on the way towards the Fram Strait as visualized in Figs. 4 and 5. The WSC has experienced progressive warming since 2004 (Walczowski and Piechura, 2007). It appears that cooling of the Atlantic Water due to lateral water mass exchange can actually be stronger than heat exchange with the atmosphere in this region (Nilsen et al., 2006). This is due to vortices generated through instabilities in the WSC at the shelf break. Detailed analysis of the iAOOS mooring data (2007-2008) shows that unstable conditions are present during $40 \%$ of the 10 -month long measurement record, depending on the localization, width and amplitude of the current jet (Teigen et al., 2010). Estimates of the contribution of isopycnal diffusion to heat loss reach 1.4 TW during the time intervals when unstable vorticity waves are active at the shelf break, implying that the dynamics of the WSC play a significant role in the cooling process of the Atlantic Water on its way to the Arctic Ocean. In contrast, estimates from iAOOS campaign data (2007) over the Yermak Plateau show that heat loss from the Atlantic core through diapycnal mixing correspond to 0.3 TW (Fer et al., 2010). This is the region (Yermak Plateau) where Atlantic Water in the Svalbard Branch (north-eastward-flowing branch of the WSC) normally starts to 


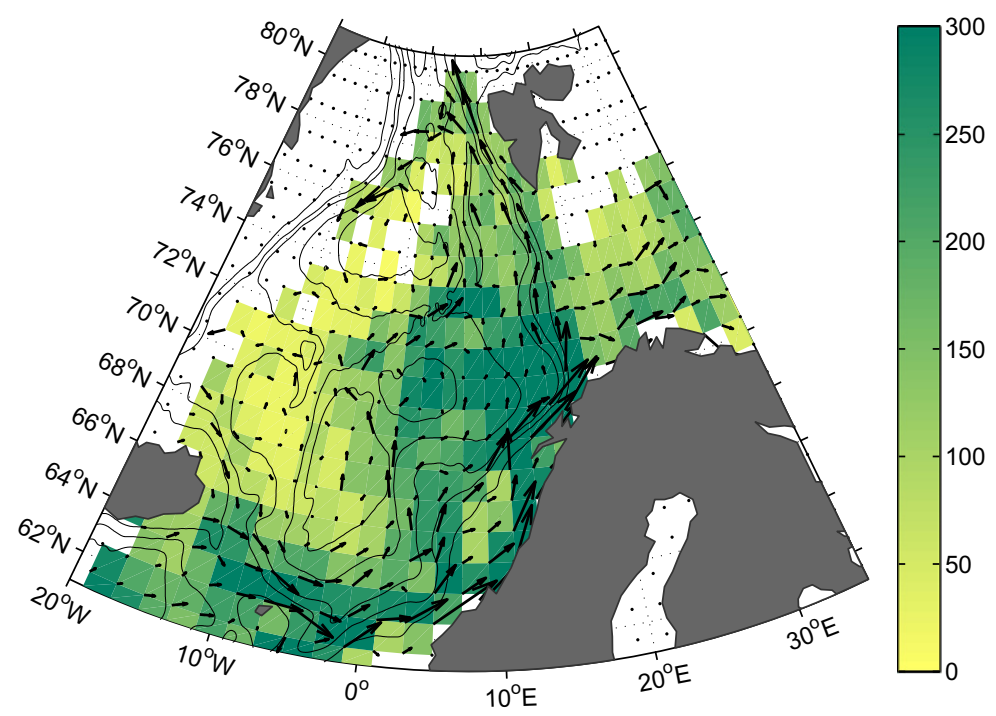

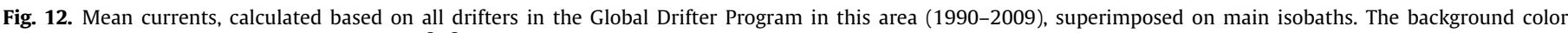
corresponds to Eddy Kinetic Energy (EKE) $\left(\mathrm{cm}^{2} / \mathrm{s}^{2}\right)$.

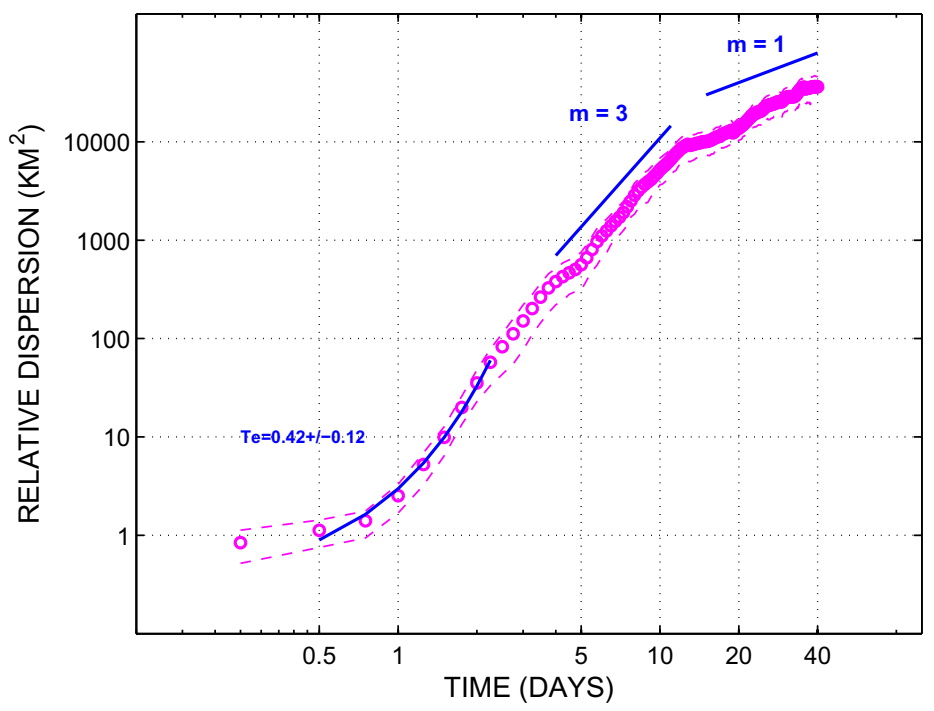

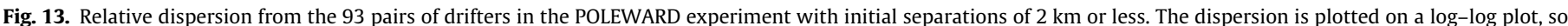

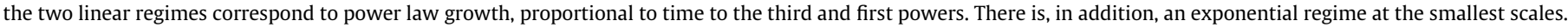
From Koszalka et al. (2009).

subduct under lighter Polar Water. However, in the winters of 2006 and 2007, large areas north of Spitsbergen were not ice covered due to anomalous warm and light Atlantic Water in the WSC (Piechura and Walczowski, 2009). Cooling by isopycnal mixing was not efficient during these years since the shelf water was replaced by Atlantic Water. The water mass replacement was set up by periods of sustained along-shelf winds generating upwelling and crossshelf exchange during the arctic winter of 2005/06, causing extensive flooding of the coastal waters with warm Atlantic Water from the WSC (Cottier et al., 2007). The winter temperature on the West Spitsbergen Shelf reverted to that typical of fall, interrupting the normal cycle of sea ice formation in the region.

\subsection{Moving through the loop: freshwater in the East Greenland Current}

The EGC is the main conduit for freshwater exiting the Arctic. It transports between $50 \%$ and $75 \%$ of liquid freshwater and sea ice exported from the Arctic Ocean (Aagaard and Carmack, 1989; Serreze et al., 2006). Several modeling studies (e.g. Stouffer et al., 2006) suggest that the volume of freshwater transported in the EGC has the potential to modulate deep water convection in the Greenland and Labrador Seas. The mean liquid freshwater flux in the EGC estimated from the mooring array in the Fram Strait relative to a reference salinity $S_{\text {ref }}=34.9$ is $-1274 \mathrm{~km}^{3} /$ year $(-40 \mathrm{mSv}$ ) (de Steur et al., 2009; see Section 2 for a description of the moorings and cruises behind this result). In addition, de Steur et al. estimate that the contribution of the East Greenland Shelf to the freshwater flux varies from $-943 \mathrm{~km}^{3} /$ year $(-30 \mathrm{mSv})$, determined from hydrographic data, to $-807 \mathrm{~km}^{3} /$ year $(-26 \mathrm{mSv})$ based on modeling results.

The most striking feature of the 1997-2008 time series of EGC liquid freshwater fluxes observed by the Fram Strait moorings is that the annual mean flux does not show any large variations since 2002. Despite the recent decrease in the summer sea ice extent in the Arctic (Comiso et al., 2008), accelerated sea ice thinning (Giles 


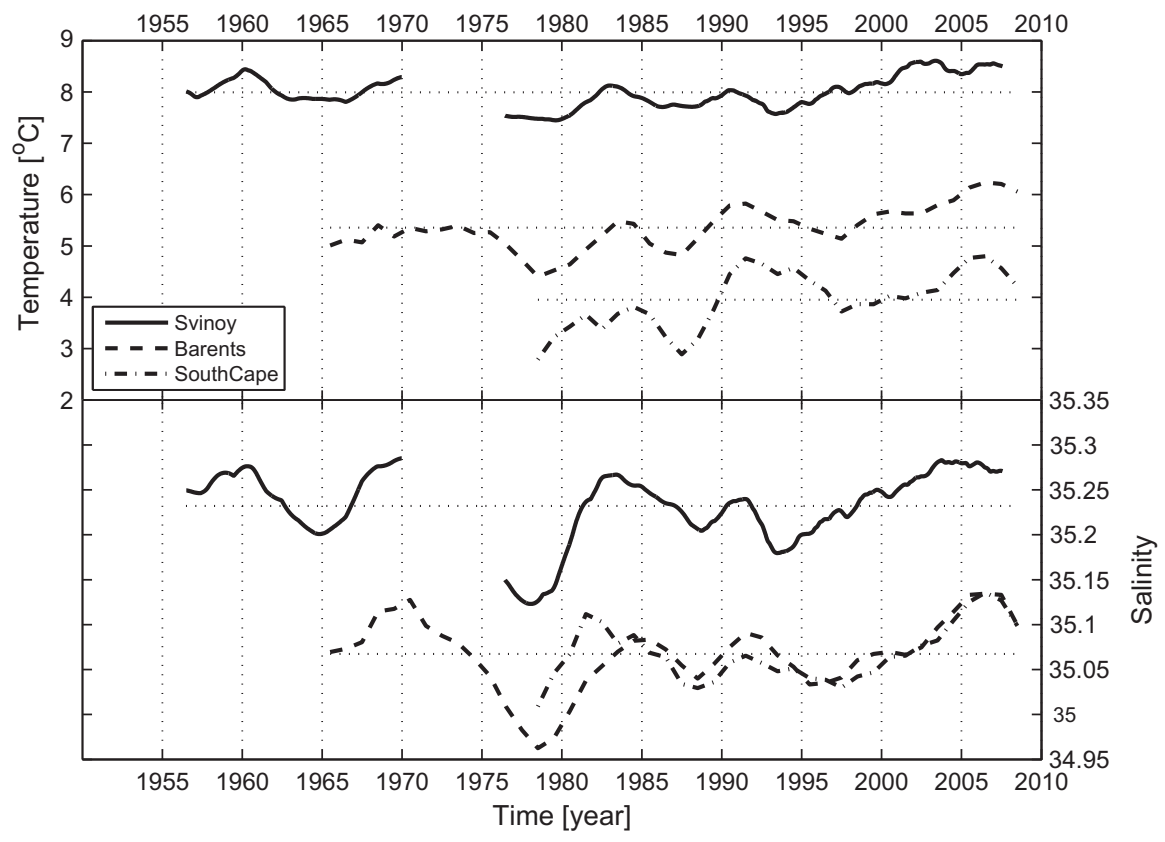

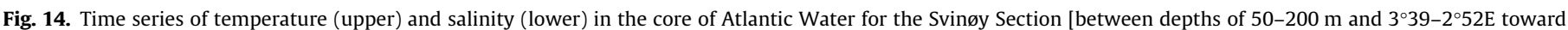

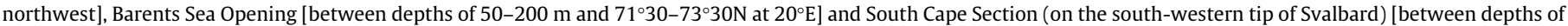

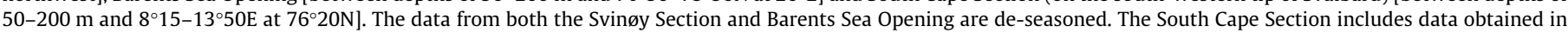

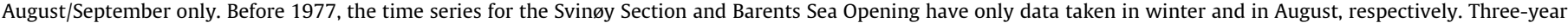
moving averages are applied on all data for the three sections.
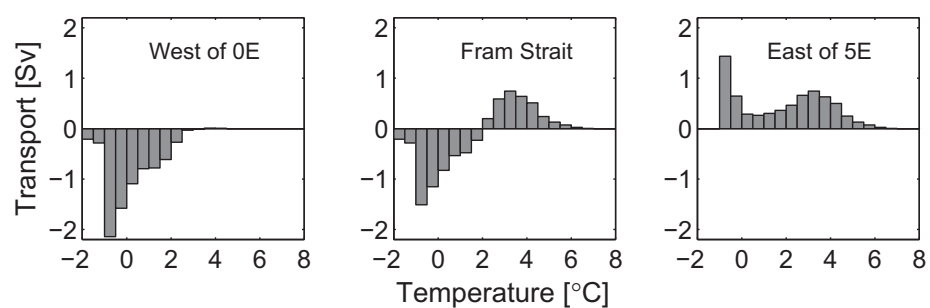

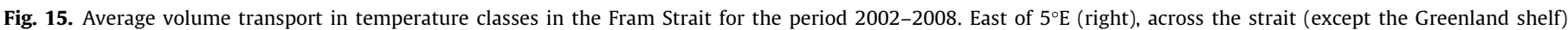
(middle) and west of $0^{\circ} \mathrm{E}$ (except the Greenland shelf) (left).

et al., 2008), and an observed increase in freshwater content in the Canadian Basin within the Arctic Ocean in 2008 (McPhee et al., 2009; Proshutinsky et al., 2009), there is no evident trend in the annual mean flux of liquid freshwater carried by the EGC through Fram Strait (de Steur et al., 2009). This indicates that freshwater is being stored in the Arctic Ocean at present. A pan-Arctic study of changes and redistribution of freshwater in the 2000s is presently underway to investigate whether these results fit with those of Proshutinsky et al. (2002), which showed that the Beaufort Gyre releases or stores freshwater following cyclonic or anticyclonic circulation regimes, respectively, or whether a totally different pattern is developing in the Arctic Ocean.

Despite the fairly constant freshwater transport observed in the EGC, the relative proportions of the freshwater outflow from the Arctic arising from sea ice, sea ice meltwater, river runoff and $\mathrm{Pa}-$ cific Water may change. Indeed, based on hydrographic data and $\delta^{18}$ O values, Rabe et al. (2009) found that over the 1998-2005 period the composition of the liquid freshwater carried by the EGC through Fram Strait did change. While their data indicate that there is no significant trend in net liquid fresh water flux, in line with de Steur et al. (2009), they observe a relative increase in meteoric water and a net formation of sea ice. The latter means that there was no increase in the amount of meltwater, but rather an increased sea ice production, which resulted in more saline water. This finding is supported by $\delta^{18} \mathrm{O}$ values sampled on iAOOS-Norway cruises, extending the $\delta^{18} \mathrm{O}$ time series through 2008 and 2009.

After the freshwater exits the Arctic through the western Fram Strait, part of it remains in the Nordic Seas and part exits to the North Atlantic. The fate of freshwater in the EGC remains an unresolved research question, which, in principle, could be investigated by the comparison of CTD and tracer measurements at various distances along the current's path. However, it has been difficult to compare CTD and tracer point measurements from the EGC that have been collected at different times of year, since it is difficult to separate spatial and long-term changes from seasonal variability without good knowledge of the seasonal cycle.

Here, we present the first results from an 18-month time series of temperature and salinity profiles relayed from sensors attached to free-swimming hooded seals that traveled within the EGC. These observations are used in combination with conventional CTD profiles to study seasonal variations in the freshwater content of the EGC. In July 2007 and March 2008, scientists from the IPY project Marine Mammals Exploring the Oceans Pole to Pole (MEOP) attached satellite relay data-loggers equipped with CTD sensors (CTD-SRDLs) to twenty hooded seals close to the East Greenland 
Shelf Break at $\sim 75^{\circ} \mathrm{N}$. As the tagged seals swam through the water column, the tags collected profiles similar to those collected by a CTD deployed from a research vessel. Profiles from the tagged seals typically spanned the upper $400 \mathrm{~m}$ of the water column, although some profiles extended below $1000 \mathrm{~m}$. The 6650 profiles collected by the seals during the deployment period, increased the number of winter and spring CTD measurements collected in the Nordic Seas significantly.

Winter and spring CTD profiles collected by hooded seals provide new insight into the seasonal cycle of freshwater thickness in the EGC. Fig. 16 illustrates the annual cycle of freshwater thickness above $100 \mathrm{~m}$ in the EGC, determined from CTD profiles between 65 and $80^{\circ} \mathrm{N}$. CTD profiles were considered to be in the EGC if they were located between $1^{\circ} \mathrm{W}$ and $5^{\circ} \mathrm{E}$ along the $500 \mathrm{~m}$ depth contour of the East Greenland Shelf Break. The freshwater includes all waters having a potential density anomaly $\sigma_{t} \leqslant 27.70$ (Rudels et al., 2002). Only the upper $100 \mathrm{~m}$ of the water column is considered here, because below $100 \mathrm{~m}$ the amount of winter data decreased dramatically.

The mean freshwater thickness in the EGC varies with an amplitude of approximately $3 \mathrm{~m}$ during the year (Fig. 16) and is highly correlated with the annual advance (September) and retreat (April) of sea ice. The low freshwater thickness values determined in February and March result from the broad definition of the EGC used in this study, which probably includes a limited number of CTD profiles located outside of the EGC. Local freezing and melting processes along the freshwater pathway complicate the understanding of the fate of the freshwater exiting the Arctic through the Fram Strait. The present quantification of the seasonal cycle will be used in the ongoing work addressing this issue.

\section{Sea ice}

Arctic sea ice has undergone rapid changes in recent years, resulting in a dramatic reduction in summer sea ice extent (e.g. Stroeve et al., 2007), a significant thinning of the remaining ice (Giles et al., 2008), and a change of the predominant ice type from multi-year ice (MYI) to first-year ice (FYI; Maslanik et al., 2007; Nghiem et al., 2007). FYI tends to be thinner and more saline than MYI with different surface characteristics that lead to larger, shallower melt ponds, which affect the summer-time absorption of solar radiation (Perovich et al., 2002; Eicken, 2003; Pedersen et al., 2009a). These changes have occurred decades sooner than was predicted by General Circulation Models (GCMs) that contain coupled sea ice components, suggesting a deficiency in the models. Such a deficiency could be due to a lack of understanding of the processes driving sea-ice melt during global warming (Stroeve et al., 2007; Wang and Overland, 2009) and limitations in the spatial resolution of current GCMs, including the inability of models to simulate the effect of inflow of warmer Pacific (Shimada et al., 2006; Woodgate et al., 2010) and Atlantic (Polyakov et al., 2005; Schauer et al., 2008) Water on the ice cover.

A review of the requirements for developing sea ice models that could represent climate and climate change (Banks et al., 2006) concluded that the most important parameters were: (1) ice extent, as it determines albedo and insulation, (2) surface properties (snow/ice/melt ponds), as they determine the albedo, and (3) ice thickness (especially of thin ice), as it determines albedo, insulation and brine rejection. Banks et al. (2006) further argue that the first priority concerning sea ice models and albedo, should be the implementation of a realistic description of melt ponds in the models, a topic that has recently received attention (e.g. Pedersen et al., 2009a).

Within the iAOOS project, we were able to observe the sea ice during this period of rapid change, and to make use of these observations and of modeling experiments to improve our understanding of these basic processes as well as of the sea ice components in large-scale models.

\subsection{Sea ice measurements}

A wide variety of measurements of sea ice have been made as a part of iAOOS. These were primarily done during the two spring (April-May) iAOOS cruises in the Fram Strait, but also during some other, related activities, including the Tara drift over the Arctic Basin, autumn (September) cruises in the Fram Strait and late-winter field campaigns on Svalbard fjord ice. This section first briefly describes the measurements made during the project and then provides an example of an application of these observations and some first results are given.

\subsubsection{Overview of IAOOS-Norway sea ice measurements}

Basic descriptive physical observations of the ice were made on many floes, both of MYI and FYI. These included transects, from

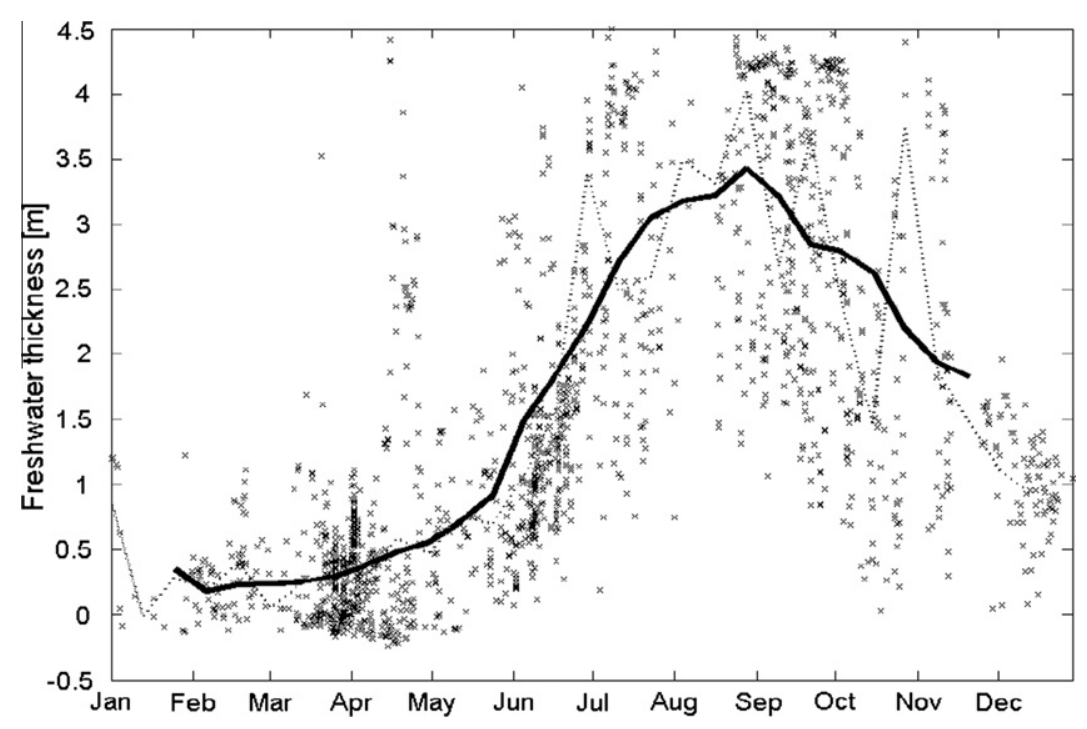

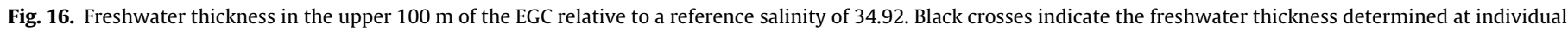
profiles. The dotted line connects 14-day mean values, while the bold line shows the data after smoothing with a 30 day mean filter. 
100 to $1000 \mathrm{~m}$ long, along which ice and snow thickness were measured every $5 \mathrm{~m}$. Snow pits were dug along the transects, in which the snow thickness, temperature, density, grain description, liquid water content, and stratigraphy were recorded. Ice cores were also collected, from which profiles of temperature, salinity, and sometimes density and chlorophyll- $a$ concentration were measured. Parallel to some of these observations, meteorological data were obtained using a mobile automatic weather station.

During the April-May 2008 cruise, total thickness (ice plus snow) was measured using a helicopter-mounted "EM-Bird" (Haas et al., 2009) along nearly $1500 \mathrm{~km}$ of flight paths over sea ice between $77.5^{\circ} \mathrm{N}$ and $81^{\circ} \mathrm{N}$ in the western Fram Strait, providing approximately 500,000 electromagnetic measurements. The frequency distribution of thickness measured on one flight leg is shown in Fig. 17. A downward-looking camera mounted on the helicopter also took wide-angle, geo-referenced photographs of the ice along the flight paths. The thickness measurements and the photos are being used for detailed assessments of the state of the sea ice in this region, in the context of validation of satellite observations and, in combination with similar datasets from other parts of the Arctic, to gain a better picture of the current thickness distribution of Arctic sea ice on large scales. Ice thickness observations are also used in the context of the long-term ice-thicknessmonitoring program of the Norwegian Polar Institute, where these measurements are compared to earlier observations in the same region (Gerland et al., 2006; Pedersen et al., 2009b).

In order to quantify the evolution of the optical properties of sea ice and its snow cover along with the other sea ice investigations, and for support of modeling (see below), spectral optical measurements of shortwave surface albedo and transmission were measured during all field campaigns. A variety of instruments and methods were used, covering a spectral range of either 320$950 \mathrm{~nm}$ or $350-2400 \mathrm{~nm}$. Furthermore, a new setup for synchronous, autonomous, continuous, and high temporal-resolution measurements of spectral albedo and transmissivity of sea ice has been developed (Nicolaus et al., 2010a). This setup is based on three RAMSES spectral radiometers, which perform well under challenging climatic conditions, over long times and during different seasons. The albedo of many surface types was measured both in late winter and in autumn. Both on the Tara drift and in Storfjorden (Spitsbergen), albedo and transmission were monitored through the melt season, providing valuable information on the seasonal evolution of the optical properties of snow and sea ice (Nicolaus et al., 2010b). At ice stations during the cruises, transmission through the ice and light transmission profiles down to $80 \mathrm{~m}$ under the ice were obtained at several locations, and through a variety of

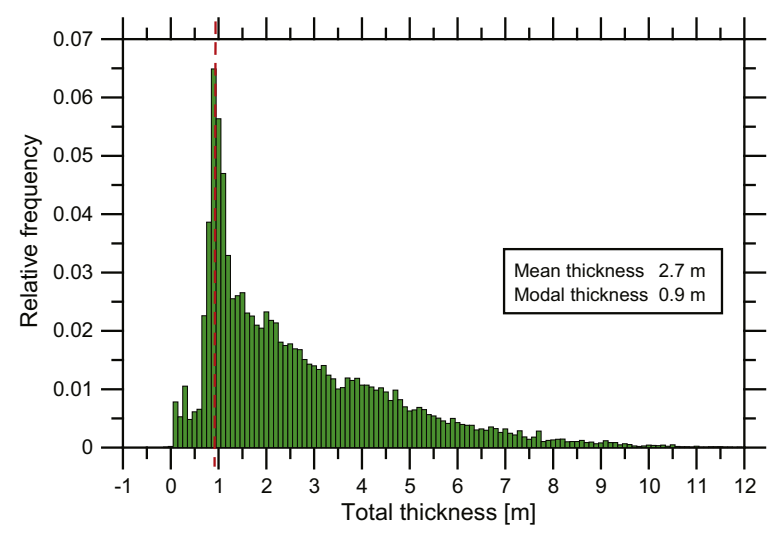

Fig. 17. A sample histogram of total (ice plus snow) thickness distribution collected by the helicopter-borne EM bird on 21 May 2008 at about $79.5^{\circ} \mathrm{N}$, between $5^{\circ} \mathrm{W}$ and $15^{\circ} \mathrm{W}$. ice types. The transmission profiles are proving useful for interpreting coincident observations of biological activity.

\subsubsection{Observations and snow albedo: albedo versus snow depth}

To illustrate the importance of considering the spatial distribution of snow depth found on sea ice, Fig. 18 shows the increase of broadband albedo with increasing snow depth. The values were computed with a radiative transfer model in which a layer of snow, represented as particles with the single-scattering albedo and asymmetry parameter of ice spheres with radius $100 \mu \mathrm{m}$, was placed on a surface with a spectrally uniform albedo of 0.5 ; incident light from the sun at a zenith angle of $70^{\circ}$ was diffused by a cloud composed of liquid water droplets with a radius of $10 \mu \mathrm{m}$, a base height of $500 \mathrm{~m}$ and an optical depth of 4 . The calculations were performed with the standard subarctic winter atmosphere (McClatchey et al., 1972) using the SBDART model (Ricchiazzi et al., 1998), an atmospheric radiative transfer model built around the plane-parallel radiative transfer code DISORT (Stamnes et al., 1988). The Henyey-Greenstein phase function was used for both the cloud and snow particles.

For simplicity, the surface beneath the snow layer was given a spectrally uniform albedo of 0.5 . This value is within the range of observed and modeled smooth, cold, bare sea ice albedo in the visible region, but too high at longer wavelengths (Grenfell, 1991; Brandt et al., 2005). The effect of finite snow depth is most important at short wavelengths, where the light easily penetrates deep into the snow, and where the snow absorbs very little light (Wiscombe and Warren, 1980), so the overly high underlying albedo at longer wavelengths will cause only a slight underestimation of the effect of finite snow depth on sea ice. The effect is clearly most important at very shallow snow depths, but even with $5-10 \mathrm{~cm}$ of snow cover, $6-15 \%$ more energy is absorbed than with $30 \mathrm{~cm}$ or more, certainly enough to affect the energy budget and therefore the processes that go on in the early part of the melt season.

Fig. 19 shows a typical distribution of snow thickness on sea ice during the melt season as observed under iAOOS-Norway (here an example from fast ice on Kongsfjorden, Svalbard). In this case, there is about $8 \%$ snow-free ice, with a mean snow depth (including the observations of zero depth) of $12.7 \mathrm{~cm}$, and a maximum depth of $30 \mathrm{~cm}$. Many such distributions, measured on different types of sea ice and at different times of year, are being used to find the best relationship between the fraction of ice with snow cover and the mean snow depth. The modeled broadband albedo of snow over sea ice as a function of snow depth, shown in Fig. 18, was

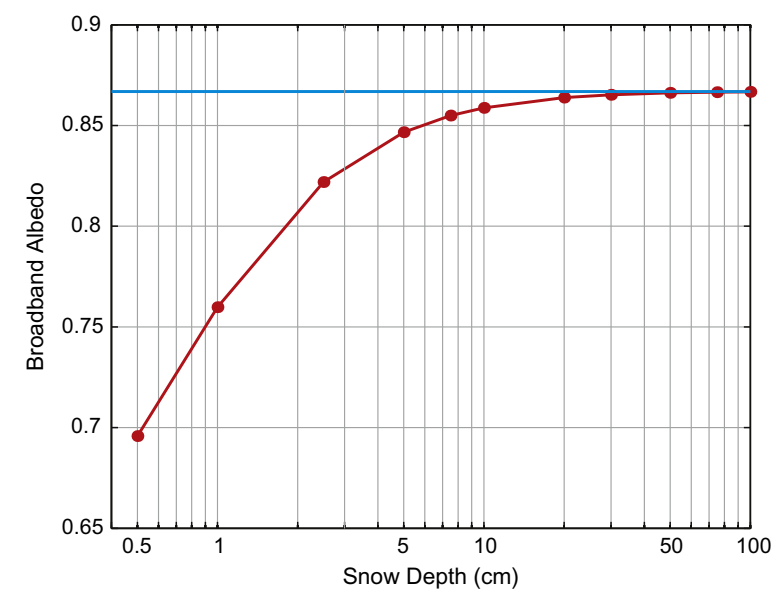

Fig. 18. Modeled broadband albedo of snow over a surface with a spectrally uniform albedo of 0.5 , as a function of snow depth. The horizontal line shows the albedo of an infinitely deep snow layer. 


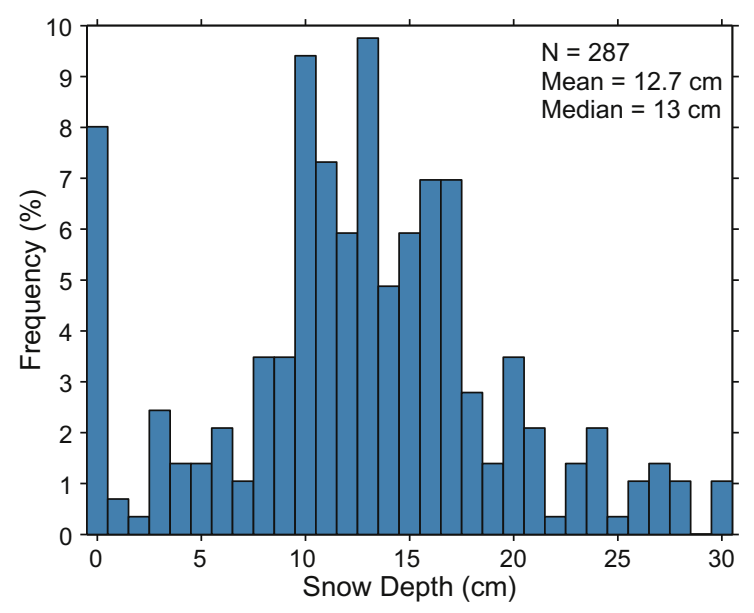

Fig. 19. The distribution of measured snow depths on a section of sea ice in Kongsfjorden in Svalbard in early May 2009.

applied to the snow depth distribution in Fig. 19. The calculated albedo of the snow-covered fraction of the area of ice represented in Fig. 19 varies from about 0.76 to 0.87 , with a mean of 0.86 . While only about $10 \%$ of the area is significantly darker than the mean, the thinner snow regions absorb up to $\sim 70 \%$ more solar energy than the areas with over $10 \mathrm{~cm}$ of snow cover, a difference that will drive local variation in melt.

\subsection{Modeling}

During iAOOS, several different modeling activities have been directed towards improving the representation of sea ice in an ocean monitoring system. The primary advance is the inclusion of an algorithm that provides a full ice thickness distribution, which has been shown to be an important factor for proper modeling of air-ice heat exchange (Bitz et al., 2001). In addition, new knowledge of the physical properties of sea ice, including salinity, and an improved description of ice surface albedo, have been incorporated. A prognostic sea ice salinity is believed to be important for modeling the transition from a predominantly MYI regime to a FYI regime because of its influence on the thermodynamic properties of the ice, and because the salt flux to the upper ocean changes during freezing. Sea ice surface albedo is important because it defines the amount of solar radiation reflected by the ice-snow surface.

\subsubsection{Sea ice sensitivity to surface albedo}

The strong sea ice albedo feedback increases climate sensitivity and might accelerate the effect of anthropogenic warming (Lindsay and Zhang, 2005). It is thus important that the sea ice albedo scheme in a climate model reproduces the pronounced annual cycle of sea ice albedo with some degree of precision. Models should be capable of describing the albedo of different surfaces as well as distinguishing between them (the transition from dry to wet melting snow, from snow-covered to pure sea ice, the formation of melt ponds and their evolution and freeze-up in autumn). Traditionally, applicable sea ice albedo schemes for climate models have been simple and have shown deficiencies in one or several parts of the annual albedo cycle (e.g. Curry et al., 2001; Køltzow, 2007; Liu et al., 2007).

To illustrate how simulated sea ice distributions are sensitive to albedo formulations we employed the one dimensional (1-D) column model described by Björk and Söderkvist (2002). This 1-D model is set up for the interior of the Arctic and is easy and fast to run, making it suitable for tests; this is in marked contrast to computer-demanding GCMs. In the model, the ice cover is described by a thickness distribution and the atmosphere is a simple two-stream gray body in radiative equilibrium. The external forcing is constant from year to year and the model is run until the sea ice thickness reaches equilibrium. Precipitation is prescribed from climatology, snow albedo is prescribed for each individual month and ice albedo is a function of ice thickness. Originally, the surface albedo equals the snow albedo when snow is present, and equals sea ice albedo when no snow is present. Note that this simplified, binary approach ignores the fact that the sea ice is partially snow covered at times. In most models, the snow-covered fraction $\left(f_{\text {snow }}\right)$ is diagnosed based on the snow depth measured in its water equivalent. This relationship often increases linearly from $0 \%$ snow cover for $0 \mathrm{~m}$ snow depth (Swe) to $100 \%$ for a given maximum snow cover depth $\left(\mathrm{Swe}_{\max }\right)$ :

$f_{\text {snow }}=\min \left(\frac{\text { Swe }}{\text { Swe }_{\max }}, 1\right)$

We applied Eq. (1) to determine the snow cover, and then calculated the surface albedo as a linear weighting between sea ice and snow albedo. This was done for several values of maximum snow cover depth, resulting in a range of sea ice thickness in equilibrium at the end of a 40-year long integration. This is shown in Fig. 20, which also illustrates the model's high sensitivity to the snow cover formulation, with differences of $20 \%$ in sea ice thickness due to the parameterization of snow cover. An increase in the choice of $S w e_{\max }$ implies that parts of the sea ice are not snow-covered, and that sea ice will therefore have increased influence on the total surface albedo. Since sea ice albedo in general is lower than snow albedo, the result is a total increase in absorbed solar energy available for melting snow and sea ice. Even though this model is more sensitive than many other models, this result still highlights the need for a proper description of snow cover in climate models in particular, and proper descriptions of different surface types and albedo in general.

\subsubsection{Atmospheric sensitivity to sea ice thickness}

As shown above and in other modeling studies, the sea ice distribution is sensitive to both internal processes and external forcing. The sea ice distribution and sea ice processes also have an

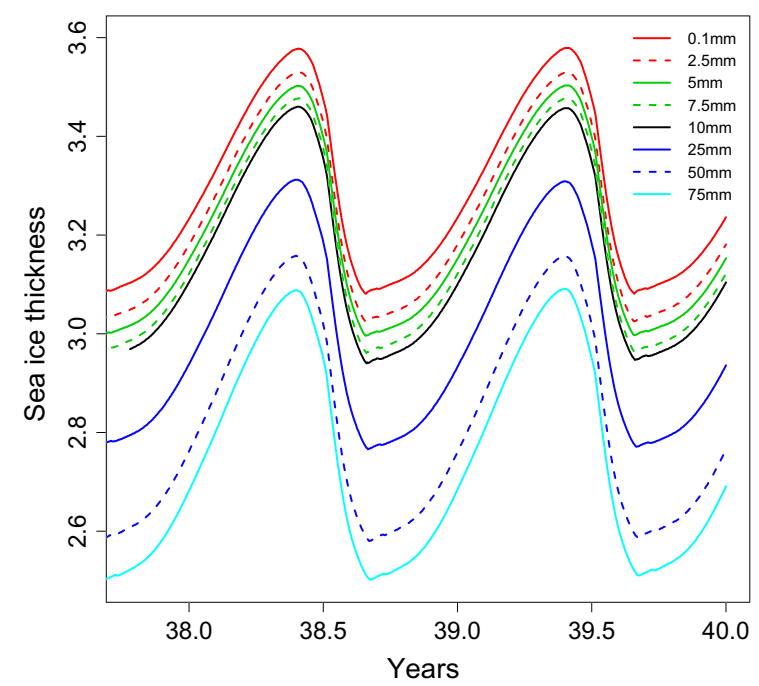

Fig. 20. Simulated sea ice thickness with parameterization of snow cover following Eq. (1). From the highest to the lowest shown simulated sea ice thickness the choice of maximum snow cover depth $S w e_{\max }$ (given in snow water equivalents) in Eq. (1) are $0.1 \mathrm{~mm}, 2.5 \mathrm{~mm}, 5 \mathrm{~mm}, 7.5 \mathrm{~mm}, 10 \mathrm{~mm}, 25 \mathrm{~mm}, 50 \mathrm{~mm}$ and $75 \mathrm{~mm}$, respectively. 
impact on other parts of the climate system (e.g. Dethloff et al. 2006; Køltzow, 2007). We illustrate this by an example with the atmospheric regional climate model HIRHAM (Christensen et al., 1996). In this model, the monthly sea surface temperature is prescribed from climatology and the ice thickness is assigned a constant value of $2 \mathrm{~m}$. The heat transfer between the ocean and the atmosphere through the sea ice is then calculated depending on the sea surface temperature, sea ice thickness and the near-surface temperature in the atmosphere model (for details, see Christensen et al., 1996). The fundamental question is: how will the atmosphere react if the sea ice thickness is reduced, for example by $1 \mathrm{~m}$ ? The model was integrated from 1990 to 1998 and forced with ERA-40 data (Uppala et al., 2005) at the boundaries. The first year was omitted in the analysis. In Figs. 21 and 22, we see the difference in mean December, January and February (DJF) $2 \mathrm{~m}$ air temperature (T2m) and mean sea level pressure (MSLP) between the two integrations.

With thinner sea ice, the model simulates a warmer arctic winter climate (Fig. 21). The impact is seen not only in regions with sea ice, but also in parts of Europe and North America. The surface air temperature over the entire Arctic Ocean becomes more than $4{ }^{\circ} \mathrm{C}$ warmer in the $1 \mathrm{~m}$ thick sea ice scenario, peaking at $6.5^{\circ} \mathrm{C}$ warmer over the central Arctic Ocean. The effect penetrates south over Scandinavia and Russia, with Scandinavia being up to $1{ }^{\circ} \mathrm{C}$ warmer. The differences are mainly due to the insulating effect of sea ice between the relatively warmer Arctic Ocean and the colder arctic atmosphere. With decreasing sea ice thickness, the sea ice surface and the near surface atmosphere become warmer due to increased heat conduction through the sea ice. During other seasons with a less pronounced temperature gradient between the ocean and the atmosphere, the impact is smaller. Furthermore, the warmer surface alters the mass distribution and the circulation patterns of the atmosphere (Fig. 22). This is only a simple example, but it can actually be seen as a lower limit of the atmospheric response to changes in sea ice distribution since the prescribed sea ice thickness distribution does not allow for feedback mechanisms in the system.

\subsection{Combining measurements and models: snow albedo}

In the list of priorities suggested by Banks et al. (2006) (Section 4), snow albedo was not included. Nevertheless, we consider snow albedo to play an important role in the surface climate of the Arctic Ocean. For instance, Warren et al. (1999) list some of the effects of snow: (1) it acts as an insulator between the sea ice and the cold atmosphere during winter; (2) when snow melts it becomes a freshwater source for the ocean and for formation of melt ponds on sea ice; and (3) snow has higher albedo than the sea ice and water-covered areas in the region. The first effect implies that snow reduces the freezing rate of sea ice on the iceocean interface during winter and delays the start of ice melting in spring/summer. The second effect may have an impact on the vertical stability of the Arctic Ocean and the formation and evolution of melt ponds on the sea ice. Melt ponds on sea ice play an important role in the surface heat budget through their absorption of solar radiation. Lastly, the fact that snow has higher albedo than sea ice and melt water implies that snow further delays the onset of sea-ice melt in spring.

Most models assume a surface albedo for snow-covered sea ice (under a given solar zenith angle) that is simply a function of snow age, temperature, or both, and either apply that to all sea ice in the grid cell, or to the snow-covered fraction of sea ice in the grid cell. In the latter case, the snow-covered fraction is a function of the modeled snow depth. Another important factor, which is not widely included and which could be important in the early melt season as the snow becomes thinner, is an appropriate distribution

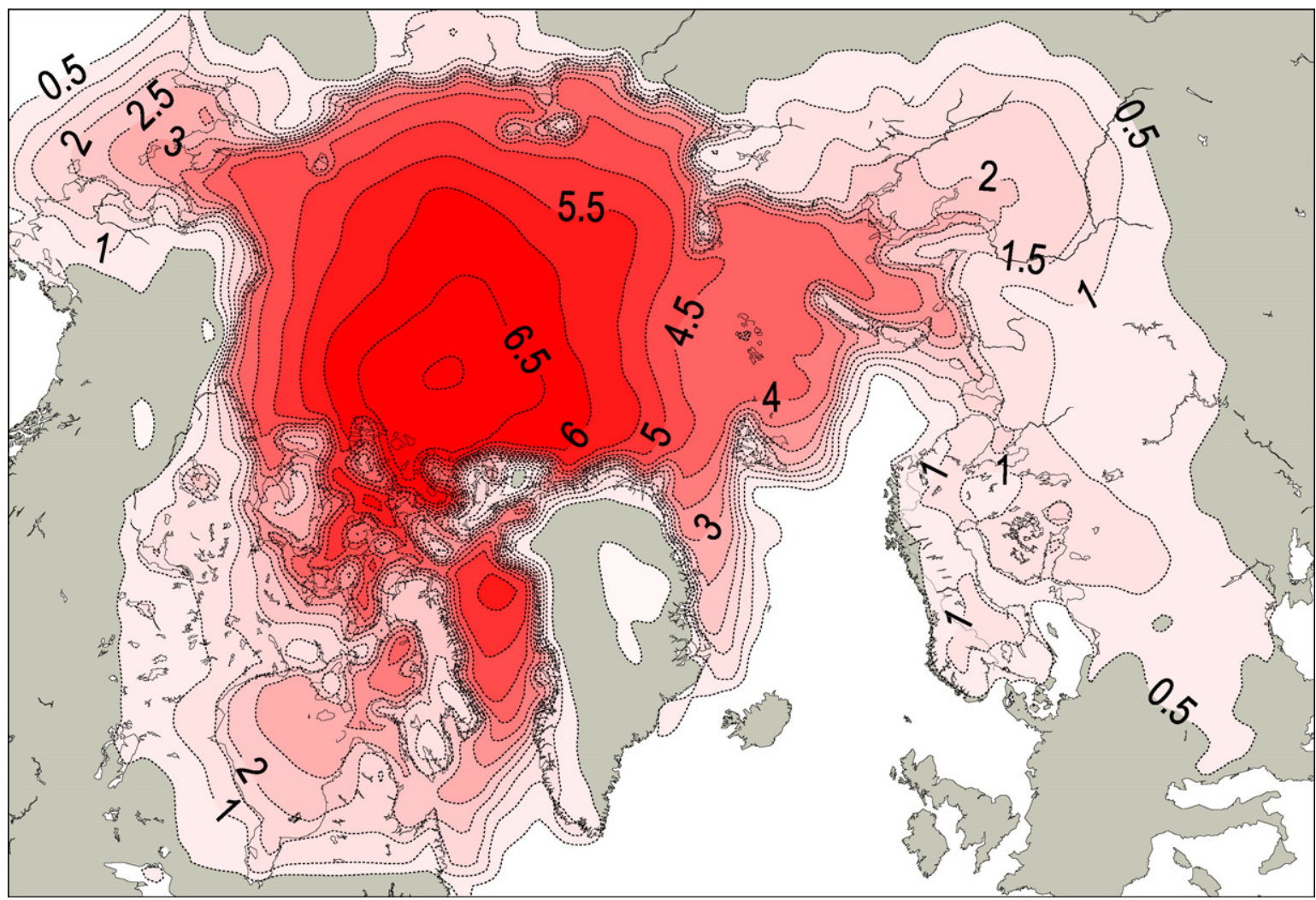

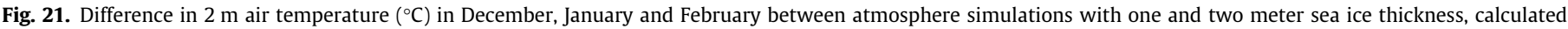
with the atmospheric regional climate model HIRHAM. Positive (red) values indicate a warmer atmosphere corresponding to thinner sea ice. 


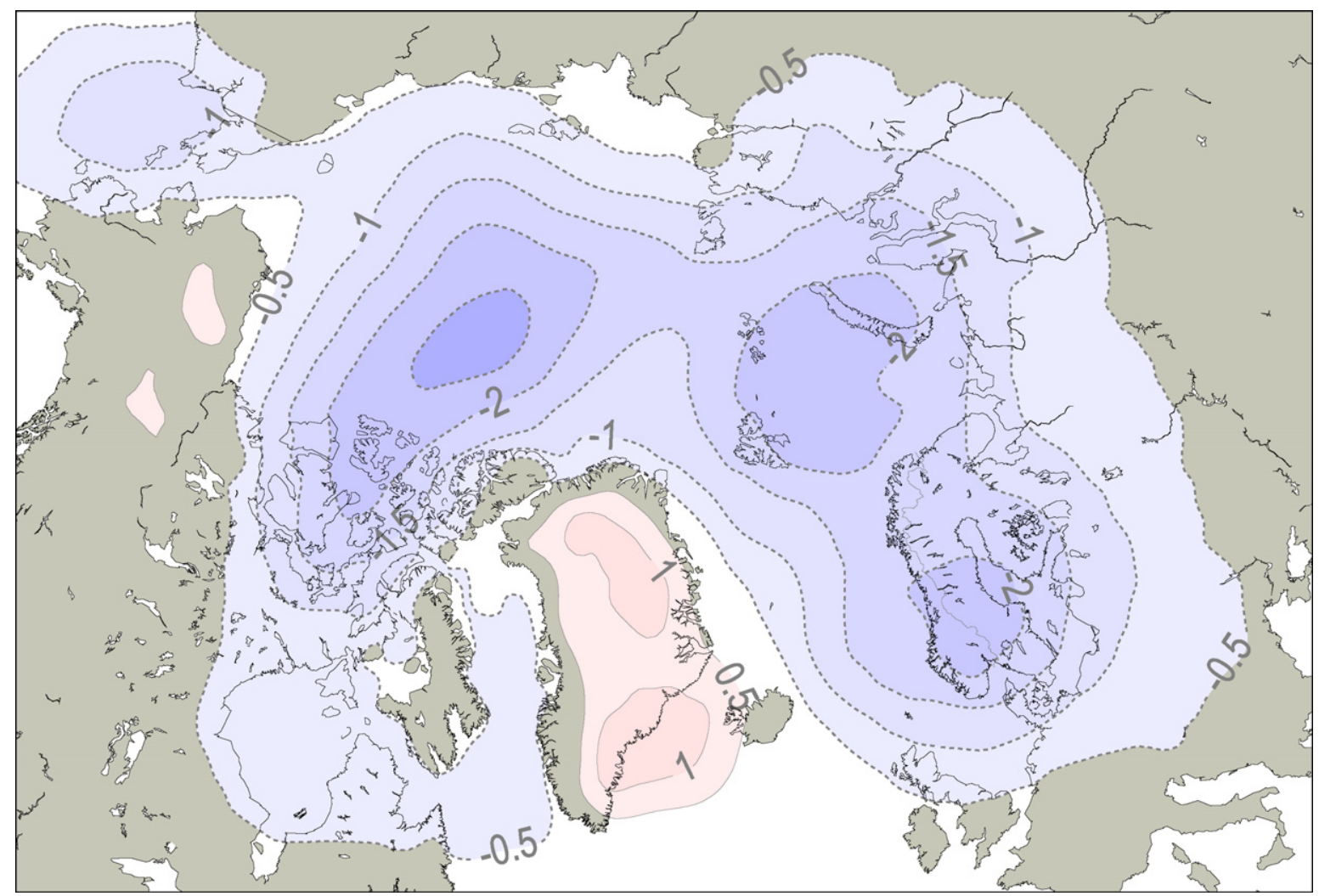

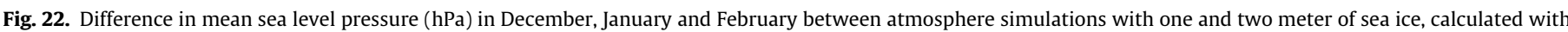
the atmospheric regional climate model HIRHAM. Negative (blue) values indicate a lower atmospheric pressure corresponding to thinner sea ice.

of snow thickness, which in turn affects the albedo and the progression of the snow cover on the sea ice. The albedo of snow depends on the snow thickness and the albedo of the underlying surface, at least when the snow is less than a minimum thickness that varies with grain size and wavelength (Wiscombe and Warren, 1980). This is an important effect to include, because the average snow depth in spring on Arctic sea ice is only around $30 \mathrm{~cm}$, and it has significant spatial variability on scales much smaller than a GCM grid cell (Warren et al., 1999). The areas with thinner snow cover will absorb more energy, mostly in the ice below the snow, which will affect the melt and metamorphosis of the snow and ice in those areas.

As Fig. 18 shows, the snow albedo varies non-linearly with snow depth. Ignoring the variation of snow depth within a grid cell can result not only in too little small-scale variability in the solar energy absorption, but can also give the wrong large-scale snow albedo. The broadband snow albedo in both the visible and nearinfrared bands varies nearly linearly with the logarithm of snow depth, over a range of depths (Marshall and Warren, 1986; Marshall and Oglesby, 1994), meaning that using the average snow depth in the cell to determine its albedo will result in too much reflectance, and therefore too little melt.

This was quantified in Section 4.1.2, where the modeled broadband snow albedo as a function of snow depth in Fig. 18 was applied on an example snow thickness section (Fig. 19). In that example we saw that the thin snow parts of the section would absorb up to $70 \%$ more solar energy than the parts of the section that had snow thickness exceeding $10 \mathrm{~cm}$. This difference would cause local variations in melt. In this particular example, using the albedo of the mean snow depth rather than the mean albedo based on the snow-depth distribution results in about $1.8 \%$ too little absorption at the grid-cell scale. Accumulated over time, this will have a significant impact on the sea ice distribution.
Due to an inherent spread in spatial scales, it is not straightforward to link iAOOS observations directly to model development. The sea ice modeling within this project typically works with 50 by $50 \mathrm{~km}$ grid cells, while the observations are made over sections of a few hundred meters. Nevertheless, the observational results enter the model development by providing conceptual understanding and by pointing toward shortcomings of the parameterizations of the models.

Energy fluxes through snow and sea ice are still among the main unknowns of sea-ice thermodynamics, even if Perovich (2005) estimated that light penetration through bare ice and ice with ponds accounts for $23 \%$ and $16 \%$ of the solar energy input into the ocean, respectively. Little is known about the vertical partitioning of solar radiation - the amount of energy absorbed in the ice, transmitted into sea-ice bottom layers and transmitted into the upper ocean and about its lateral variability (Perovich et al., 1998). Quantifying these key processes is critical for understanding atmosphere - ice ocean interactions, and how these may change in the future.

\section{Biology}

The tremendous physical contrasts across the Fram Strait, with warm Atlantic Water on the eastern side and cold ice-covered arctic water masses on the western part of the Strait, set the scene for the biological productivity and community structure. Primary productivity - and with it community structure and ecosystem functioning - in arctic marine systems is strongly related to the presence of ice, modifying the seasonal light cycle, as well as the supply of nutrients at the onset of and throughout the productive season (Fig. 23; Sakshaug, 2004).

In contrast to the long history of observations and monitoring of physical parameters in arctic regions, long-term observations of 
marine biological parameters in arctic regions are scarce, and the information that does exist is mainly related to snapshot sampling performed during summer cruises. Thus there is a paucity of long time series and data from winter and early spring periods, when ship-based sampling is difficult due to ice and darkness. A few biological observational sites have recently been established in Svalbard (by the University Centre in Svalbard/Norwegian Polar Institute, Norway; by the Scottish Association for Marine Science, Great Britain), adding to the benthic monitoring site Hausgarten in the Fram Strait (run by the Alfred Wegener Institute), but lack of long-term data series makes it difficult to separate change from variability. We know more about the eastern side of the loop than about the ice-covered western side of the strait, because it is easier to access the former.

The biological sampling program of iAOOS-Norway focused on the Arctic Ocean out-flow along the East Greenland Shelf in the early spring, in order to improve our understanding of the onset of the productive season, the composition and role of organisms at low trophic levels as well as the spatial variability on the East Greenland Shelf during two successive years of sampling. Continuous measurements over 6 weeks with KV Svalbard combined with cross-shelf transects carried out by helicopter in April 2007 and April-May 2008 (see Section 2) provided unique spatial and temporal resolution. The area was revisited with RV Jan Mayen in mid-May 2007, and with the two RV Lance cruises mentioned in Section 2, providing seasonal coverage of the lower trophic level ecosystem components through the course of 2 years.

Here, we focus on preliminary findings illustrating dynamics, timing and spatial variation on the East Greenland Shelf in early spring compared to that on the Atlantic-influenced eastern side of the Fram Strait.

\subsection{Phytoplankton production}

The amount of carbon fixed through primary production annually provides the energetic basis for the whole ecosystem. Annual primary production is logistically very difficult to measure in remote systems like the Fram Strait; however, physical-biological coupled models like the SINMOD, can provide reliable estimates of rates and spatial variability (Slagstad and McClimans, 2005; Wassmann et al., 2006; Ellingsen et al., 2008). For the Fram Strait region, recent simulations by this model suggest a productivity regime of $100-140 \mathrm{~g} \mathrm{C} \mathrm{m}^{-2} \mathrm{yr}^{-1}$ in the waters influenced by northward-flowing AW, with a sharp decrease towards the west close to the East Greenland Shelf Break (Reigstad et al., this volume). In the out-flow region on the North-East Greenland Shelf, the simulated annual primary production drops to about half the values to the east, $40-60 \mathrm{~g} \mathrm{C} \mathrm{m}^{-2} \mathrm{yr}^{-1}$. The main regulating factor is the ice cover, which determines the length of the productive season.

\subsection{When does growth start in spring?}

The East Greenland Shelf and Shelf Break are covered by dense drift-ice from the Arctic Ocean, making light the limiting factor for biological production in spring, despite midnight sun. During our investigations in April and May, we detected the start of the productive season. In this period, small signals of increased activity were observed at various trophic levels, as well as an accumulation of biomass and increased vertical export of organic matter to depth. Nutrients were available at winter concentrations.

An important finding was the distribution and low concentrations of winter-accumulated nitrate in the surface waters along a transect from the shelf break and onto the East Greenland Shelf at $78^{\circ} \mathrm{N}$. While winter concentrations of $10-12 \mu \mathrm{M} \mathrm{NO}_{3}$ are typical for the Barents Sea and Atlantic Water (Reigstad et al., 2002), the nitrate concentrations on the East Greenland shelf decreased from similar concentrations in the AW water at the shelf break to concentrations $<3 \mu \mathrm{M} \mathrm{NO}_{3}$ on the shelf (Fig. 24). The nitrate concentrations were closely associated with the water masses indicated through salinity, with lowest concentrations in less saline Polar surface waters compared to the more saline Atlantic Water. Dense drift-ice characterized the entire transect, and the algal biomass

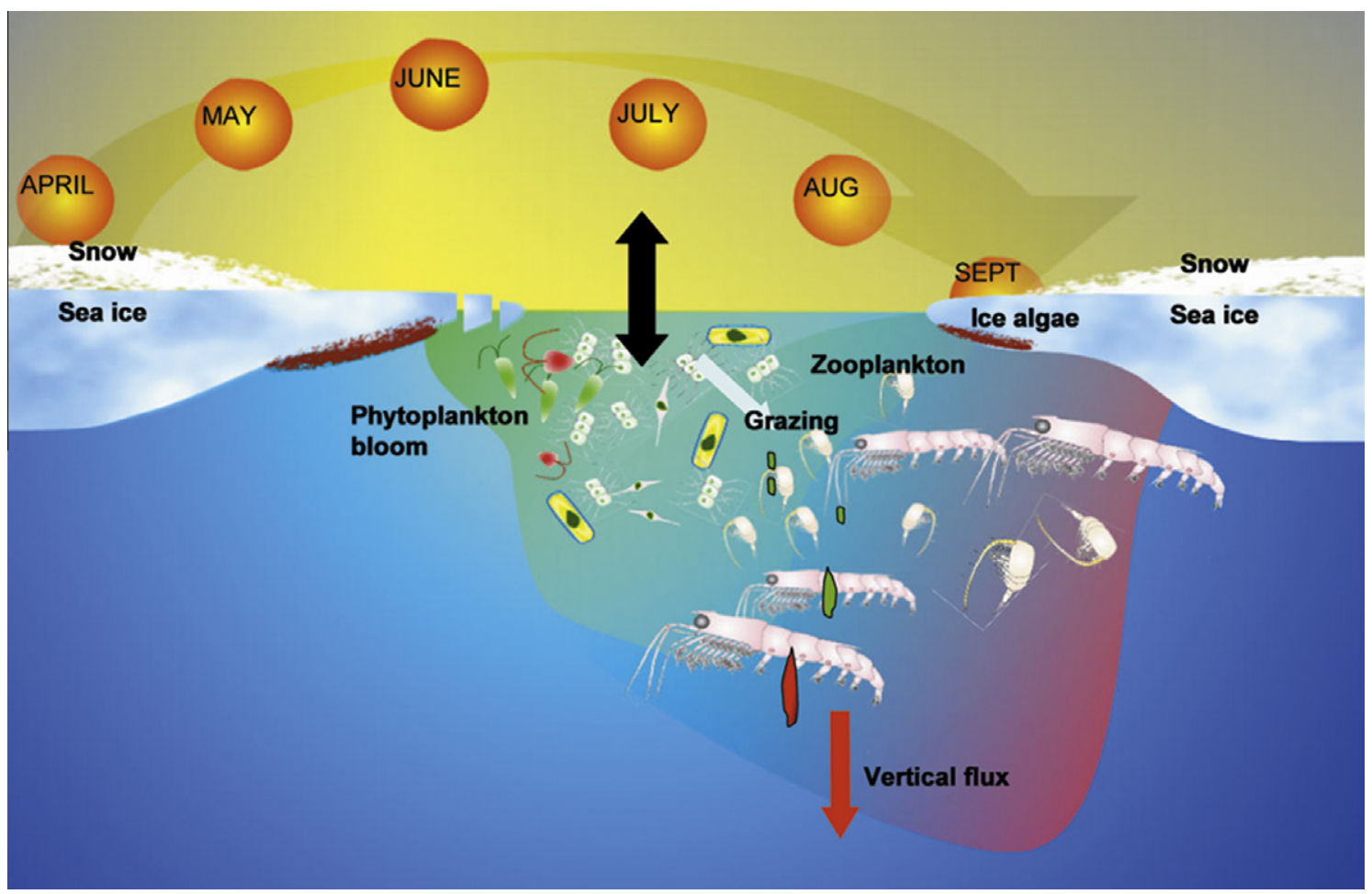

Fig. 23. Annual cycle of physical forcing and biological response in the Arctic (Wassmann et al., 2004). 

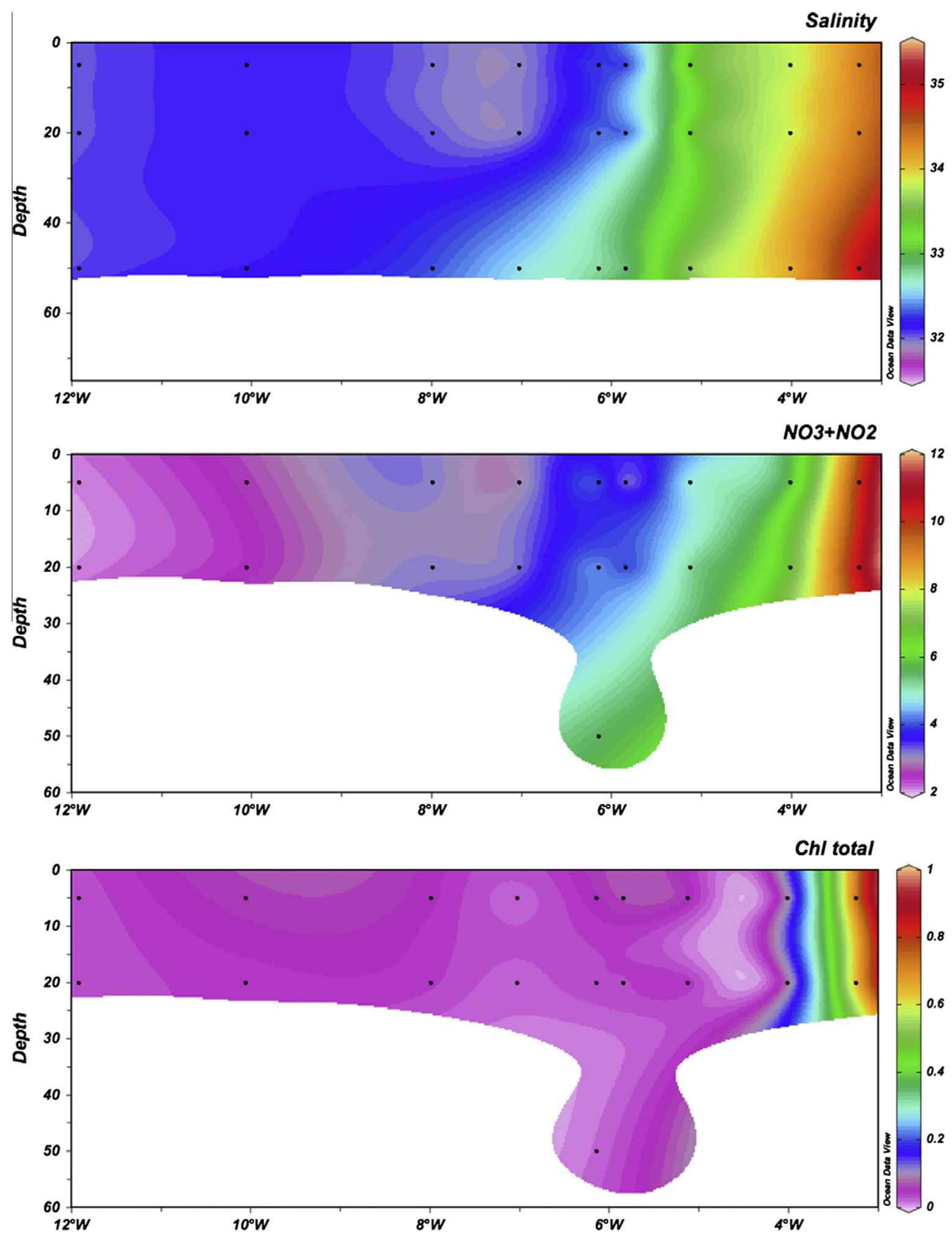

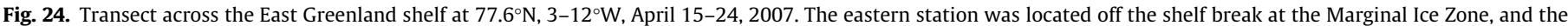

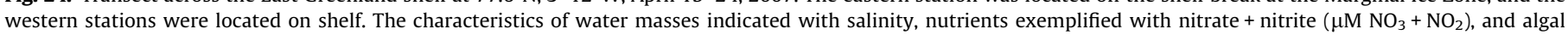
pigment Chl $a\left(\mathrm{mg} \mathrm{Chl} a \mathrm{~m}^{3}\right)$ are given for the surface layer.

was negligible across the shelf except at the eastern ice edge, supporting pre-bloom conditions on the shelf. With such low concentrations of winter-accumulated nitrate on the shelf, the potential productivity in this region will be considerably constrained. Similar low - and even decreasing - nitrate concentrations are reported from Canadian Arctic surface waters (Tremblay et al., 2008; Li et al.,
2009), and this supports a scenario of nutrient-limited primary production as a consequence of decreasing ice cover for larger regions of the Arctic Ocean.

Winter- or pre-bloom concentrations of pigments and suspended organic matter were similar to levels observed in Arctic and Atlantic regions of the Barents Sea in March (Reigstad et al., 
2002). Most of the copepod community stayed below $60 \mathrm{~m}$ depth. Large Calanus spp. stages (CIV and CV) returning from over-wintering at depth to mature and reproduce (C. Svensen, unpublished data) dominated the zooplankton community. Over a period of 10 days, the vertical copepod distribution shifted to surface dominance, indicating increased productivity and food supply. The algal biomass did not increase notably in this period and the vertical export was negligible, suggesting that the grazing pressure from the starved zooplankton matched primary production.

Studies of planktonic flagellates and ciliates were emphasized in iAOOS-Norway, because although these single-celled organisms are known to play an important role in temperate and warmer marine ecosystems, they have received little attention in Polar Regions to date. During all iAOOS cruises, nanoflagellates, dinoflagellates, and ciliates were found at numbers comparable to those reported from warmer areas (Levinsen and Nielsen, 2002; Huang et al., 2008). Furthermore, the taxonomic composition did not differ from that reported from other areas (Levinsen and Nielsen, 2002). However, a surprising dominance of the autotrophic ciliate Myrionecta rubra was found in ice-covered regions in spring (April), where it constituted a major fraction of the suspended chlorophyll $a$ in the size-fraction $>10 \mu \mathrm{m}$. Thus, autotrophic ciliates and flagellates seemed to be the major primary producers in ice-covered waters in early spring. A month later (May), a diatom bloom was encountered in the same region and heterotrophic ciliate and flagellates were found at high abundances. Food availability rather than temperature seemed to control ciliate and flagellate growth and abundance. Estimates of the grazing pressure of ciliates and flagellates indicate that these organisms are important grazers in the area studied. Another group of grazers that normally receives minor attention is the small copepods. They are usually strongly underestimated due to the standard zooplankton sampling with mesh size of $200 \mu \mathrm{m}$ (Pasternak et al., 2000). We included sampling with finer mesh nets and bottles $(90 \mu \mathrm{m}$, Go-Flo bottles) and revealed that smaller copepods constituted a considerable fraction of the copepod community. Consequently, small copepods, ciliates and flagellates need to be considered in Arctic regions if carbon and nutrient cycling is to be understood.

The considerable increase in the biological production, biomasses and vertical export of organic matter observed from April to May 2007 within the drift-ice, illustrated a highly dynamic system with Chlorophyll $a$ (Chl $a$ ) concentrations increasing from $<0.05$ to $10 \mathrm{mg} \mathrm{m}^{-3}$ within a few weeks. The algal community changed from a dominance of small $(<10 \mu \mathrm{m})$ cells to large cells over this period. Vertical export rates of organic matter also increased by a factor of 10-100 during this period. The rapid changes were illustrated at one station where vertical export of particulate organic carbon, pigments and fecal pellets from zooplankton increased by a factor of $>10$ over a few days.

\subsection{Arctic versus Atlantic; a key to understanding a warmer future?}

Across the Fram Strait and in the Barents Sea, highly different production systems exist at similar latitudes, because of AW inflow and export of ice and Arctic Water (Hirche et al., 1991; Sakshaug, 2004; Hop et al., 2006; Hirche and Kosobokova, 2007). Comparative studies of these systems can help identify potential consequences of future change in sea ice extent and seasonal dynamics. The short productive season on the East Greenland Shelf results in an annual primary production of only half of that on the eastern, Atlantic-influenced side. Nevertheless, observed biomasses and export rates in the Marginal Ice Zone of the western Fram Strait were comparable to observations from the Marginal Ice Zone in the Barents Sea (Olli et al., 2002; Reigstad et al., 2002). The integrated Chl $a$, as a measure of phytoplankton biomass, observed in Arctic waters in the East Greenland Marginal
Ice Zone in late May 2007, $192 \mathrm{mg} \mathrm{Chl} a \mathrm{~m}^{-2}\left(0-40 \mathrm{~m}, 78^{\circ} 56 \mathrm{~N}\right.$, $00^{\circ} 37 \mathrm{~W}$ ) was twice the maximum biomass observed by Hirche et al. (1991) in the same region along a transect from the open polynya through the pack ice to the Marginal Ice Zone in June/July, and five times the biomass observed by Gradinger and Baumann (1991) in June/July in the same region. High spatial and temporal variability is the rule in such heterogeneous environments, but with possible increased light due to reduced amount of thick multi-year ice (see Section 4), we can speculate that phytoplankton blooms might occur earlier in the year.

The onset and length of the productive season are determining factors for the composition of key organisms in the ecosystem. Theoretically, the copepod community composition should be different across the Strait, with Atlantic species such as Calanus finmarchicus on the eastern side, and arctic species such as Calanus glacialis on the western side, in line with their physiological optima (Hirche et al., 1991; Falk-Petersen et al., 2009). However, due to the complex current system in the Fram Strait, Atlantic species are advected and redistributed to the East Greenland side with the Atlantic return flow (Hop et al., 2006; Hirche and Kosobokova, 2007). Hirche and Kosobokova (2007) suggest that the reproductive success of these copepods is more sensitive to food limitation than to low temperatures in early spring. A change in ice conditions in the Arctic Ocean and the Fram Strait, with less multi-year ice, thinner and smaller ice floes, and in particular less or changing snow cover on the ice, can create a situation favoring earlier blooms and a shift in the species that dominate the East Greenland Shelf and MIZ. However, in the future, annual primary productivity will likely be limited by the low winter-accumulated nitrate concentrations in the upper water layer. This observation on the East Greenland Shelf probably reflects a pattern that will become the norm across larger regions of the upper Arctic Ocean.

\section{Forecasting ocean and ice conditions in the High North}

One aspect of public service has received direct attention in iAOOS-Norway, namely short-term ocean and ice forecasting. Activities at sea in northern regions depend not only on reliable weather forecasts, but also on good forecasts of the sea ice movement and ocean currents. Safe navigation, safe operations, and successful rescue operations depend crucially on good forecasts of all these three regimes. We have therefore made a particular effort in iAOOS-Norway to ensure that the public forecasting services at the Norwegian Meteorological Institute benefit directly from the new observations, the new process understanding, and the new modeling capabilities obtained during IPY.

The present-day official operational ocean services at the Norwegian Meteorological Institute consist of sea level and wave height forecasts, as well as sea ice charts and a number of other special products. In case of emergencies (oil spills, pollution, and search and rescue missions) forecasts of ocean currents are used to narrow down the search. For the general public the institute provides "marinograms" with 2-day forecasts of surface currents, sea level height, air temperature and pressure, wind and waves for any given position (Fig. 25).

Providing an operational ocean- and ice-forecasting system involves exploiting the synergies between state-of-the-art coupled ocean and ice models and near-real-time observations, both from satellite and from in situ instruments. Although not as advanced as for weather prediction, the observation network accessible in near real time for the ocean and forecasting is constantly growing and now includes both remote sensing products (processed from satellite signals) and in situ measurements. These are complementary as they do not sample the same scales or regions of the model domain. We present here advances made using data and models 


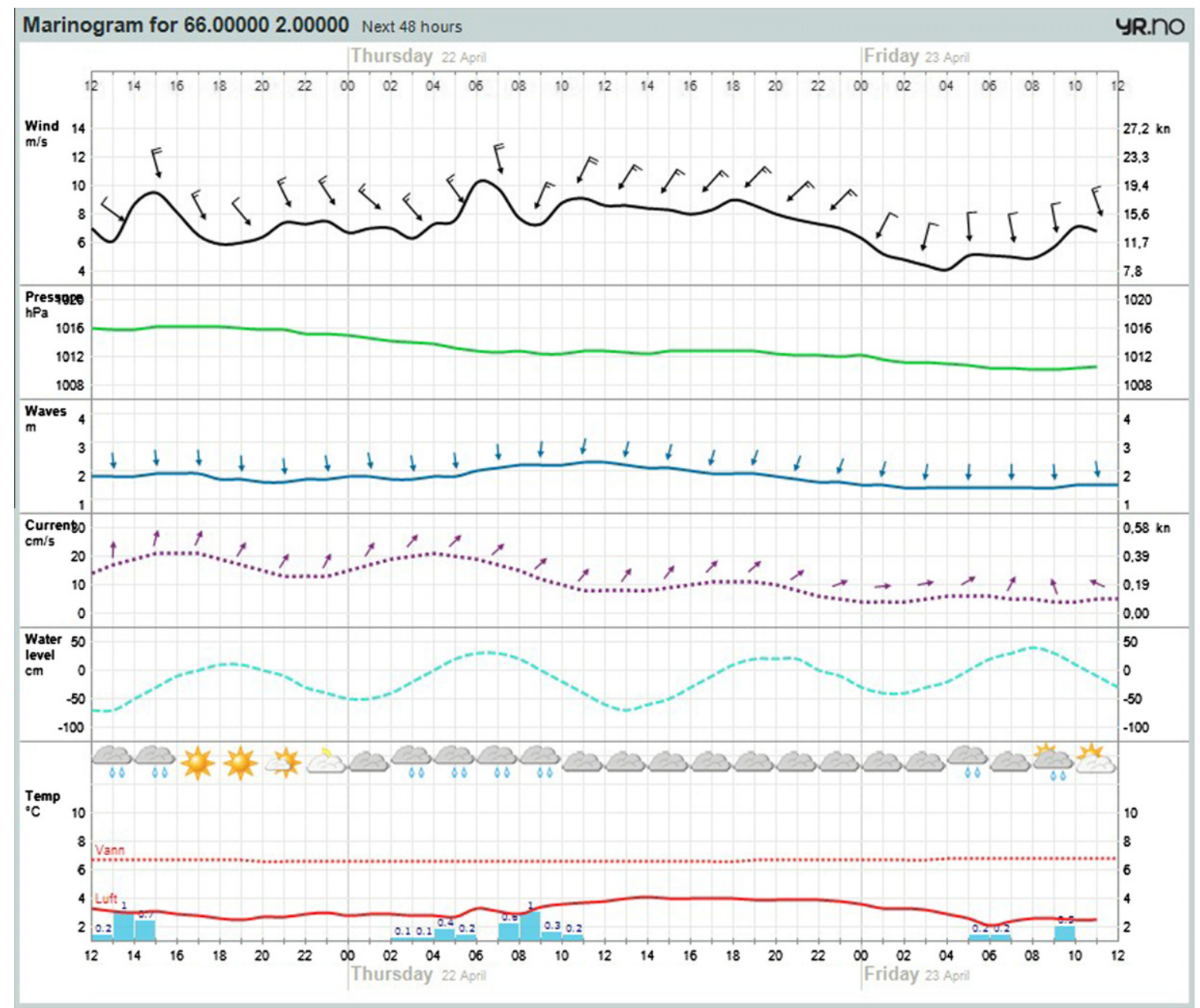

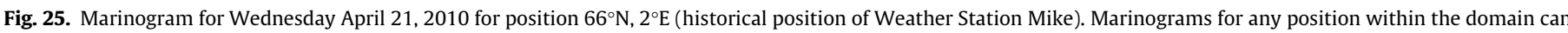
be obtained at www.yr.no/hav_og_kyst.

within the three fields (1) improvement of data products, (2) validation and (3) data assimilation.

\subsection{Improvement of data products: sea ice motion}

Some key ocean and ice parameters are not sampled by current operational satellites. One of these parameters is sea ice thickness, which, as discussed in Section 4, is important for many aspects of our climate system, such as atmospheric temperatures, radiation balance and biological activity, as well as for short-term weather forecasting (Section 4.2.2). In recent years, Arctic sea ice measurements have been made possible by instruments on board ICESat (Kwok and Cunningham, 2008) and European Space Agency (ESA) (Laxon et al., 2003) research platforms. New satellite missions, like the European CryoSat-2, will enhance the temporal and spatial resolution of measurements and might lead to operational and near real time measurement of sea ice thickness.

Several investigators have shown that assimilation of sea ice motion has a significant potential in indirectly constraining the sea ice thickness, given sufficient spatial data coverage. Since the end of the 1990s, sea ice motion has been reliably retrieved from a variety of satellite-borne sensors. The sensors that give the best coverage are passive and active microwave instruments like the Special Sensor Microwave/Imager (SSM/I) and the scatterometer SeaWinds/QuikSCAT. However, the rather simple algorithms used for extracting motion vectors from those low-resolution images, e.g. the well-known Maximum Cross Correlation (MCC) method, leads to rather long time displacements. The ice drift products available from the French Research Institute for Exploitation of the Sea (IFREMER), for example, have a 3-day lag time (Ezraty et al., 2007). A 3-day average drift is not a very realistic representation of the initial state ("now"). Therefore, there is a growing interest in products that are closer to real-time situations.

In iAOOS-Norway, we have shortened the 3-day lag to a 2-day lag by developing a continuous formulation: the Continuous MCC (CMCC) (Fig. 26; Lavergne et al., 2010). The CMCC strongly dampens the quantization noise and allows drift vectors with shorter time spans. Strategies for optimally merging the information content from different imaging channels, as well as detecting and correcting for the few dubious vectors that arise during the processing, have also been developed. The algorithms have been implemented in the EUMETSAT Ocean and Sea Ice Satellite Application Facility chain, which processes single-sensor ice drift vectors from the AMSR-E, SSM/I and ASCAT sensors. An operational data-stream delivers near-real-time ice motion products to ocean and ice forecasting centers.

\subsection{Validation}

The accuracy of products and forecasts is routinely validated. The single-sensor satellite sea ice drift products presented above have been validated against in situ drifters over a 3-year period, from 2006 to 2009. The validation dataset comprises GPS positions of the ice-tethered profilers (see Section 6.3), the Tara schooner 

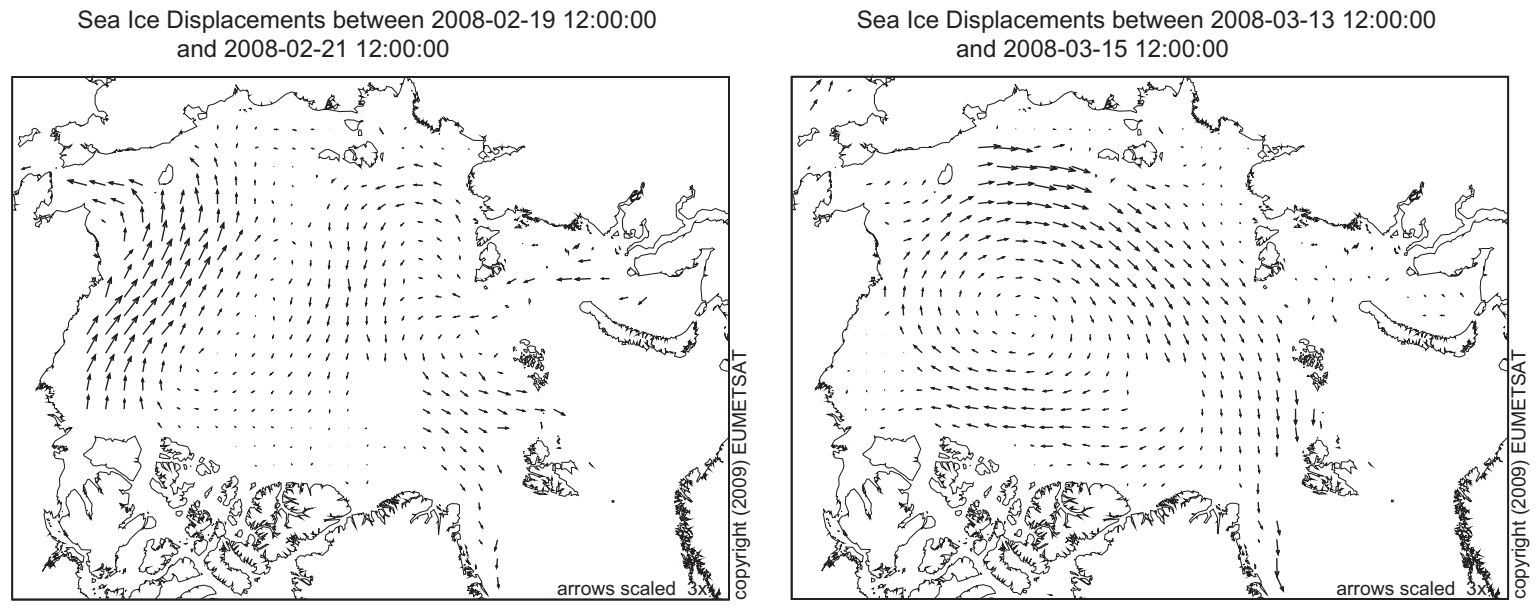

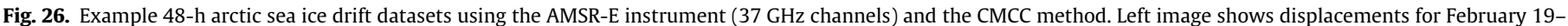
21, 2008; right image represents March 13-15, 2008.

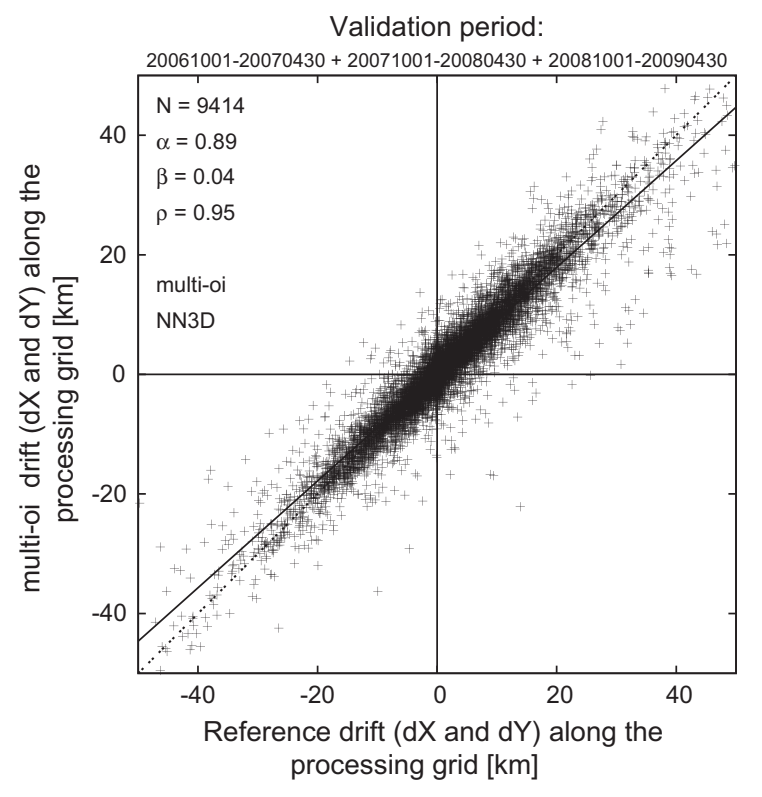

Fig. 27. Validation graph between the CMCC-based, multi-sensor, ice motion product ( $y$ axis) and the reference dataset comprising GPS trajectories of in situ drifters. The validation period covers three autumn-winter-spring seasons, from October 2006 to April 2009.

and the Russian floating ice stations NP-35 and NP-36, all deployed or collected during IPY.

Validation statistics document an un-biased agreement between the AMSR-E, SSM/I and ASCAT products and the GPS trajectories, with standard deviation of the errors in the components of the drift vectors ranging from $2.5 \mathrm{~km}$ to $4.5 \mathrm{~km}$ depending on the sensor. The AMSR-E sensor allows for the best statistics even without using the highest-resolution $(89 \mathrm{GHz}$ ) channels (Lavergne, 2010).

From these single-sensor ice drift products, a multi-sensor product (yielding more complete data coverage) was also processed and validated during the iAOOS-Norway project. Fig. 27 shows its validation statistics. The Pearson correlation coefficient is as high as 0.95 and the associated standard deviation of the errors is $3.7 \mathrm{~km}(4.0 \mathrm{~km})$ in the $x(y)$ component of the 2-day motion vectors.

In situdata from iAOOS-Norway have been used for validation of forecasts. As an example of the new possibilities for ocean current validation, we show results from using the Seaglider at Svinøy (see

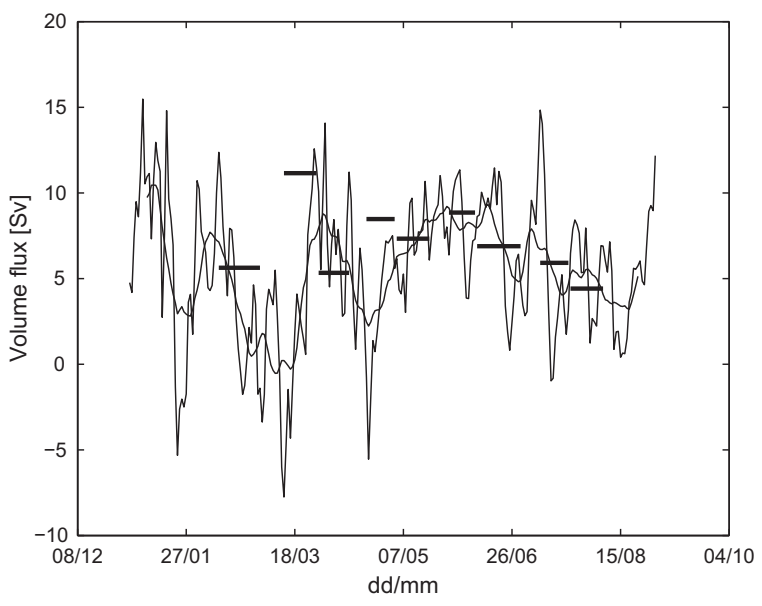

Fig. 28. Nordic-4 km (the Norwegian Meteorological Institute operational MIPOM ocean forecast model) volume fluxes (thin gray line: daily values; thin black line: 15-day low-pass filter) and Seaglider volume fluxes (thick black lines) of the outer branch at Svinøy. The Seaglider transport is computed using cross-sectional geostrophic velocities referenced to the cross-sectional, depth-averaged current as measured by the Seaglider. The area is defined by the geographical limits between $63.29^{\circ} \mathrm{N} 3.30^{\circ} \mathrm{E}$ and $65.1^{\circ} \mathrm{N} 1^{\circ} \mathrm{W}$, over topography deeper than $1100 \mathrm{~m}$ and salinities higher than 35 .

Section 3.3). We have compared the ocean transport between $63.29^{\circ} \mathrm{N}, 3.30^{\circ} \mathrm{E}$ and $65.1^{\circ} \mathrm{N}, 1^{\circ} \mathrm{W}$ (Svinøy outer branch; see Section 3.3) in the ocean forecasting model to that computed from the nine Seaglider crossings from January to September 2009 (Fig. 28). The strength of the current (around $6 \mathrm{~Sv}$ ) and to some extent the time variability are represented in the model. The precision in forecasting actual velocity vectors in an ocean forecasting model is usually low, because small, energetic eddies often dominate the current field. Nevertheless, the model appears to forecast integrated values such as volume flux quite well, which reflects that the total air-sea fluxes of momentum and energy (i.e. the total forcing) in the model are quite realistic. Note that there has been no sub-surface data assimilation in the model run presented in Fig. 28.

\subsection{Data assimilation}

An important prerequisite for high-quality forecasting is a good initial state. This is the phase of the forecasting when models and 

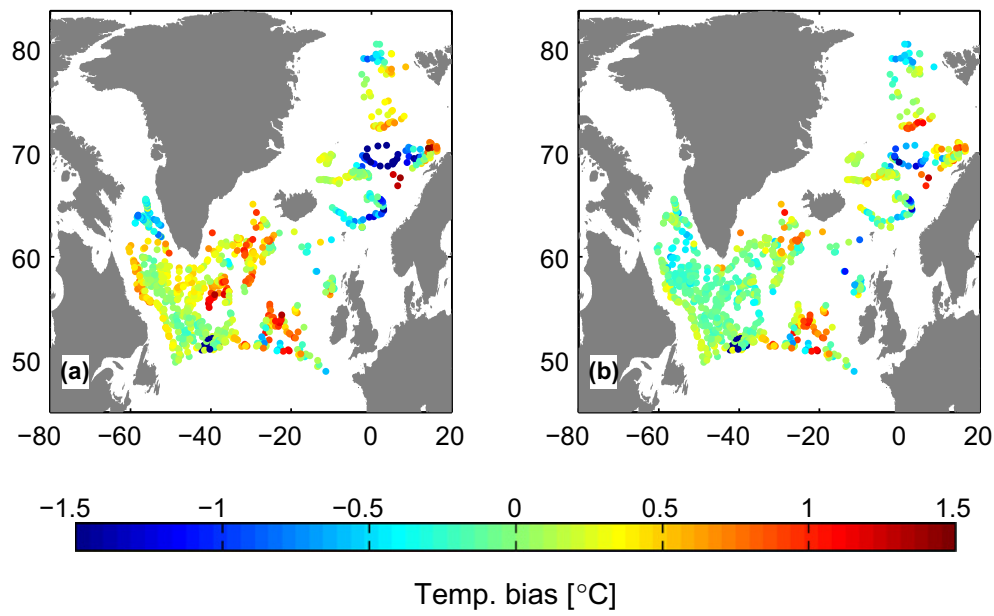

Fig. 29. Depth-integrated temperature bias in met. no's ROMS Arctic-20 km model (a) before and (b) after assimilation of ARGO data for the period January-July 2007.
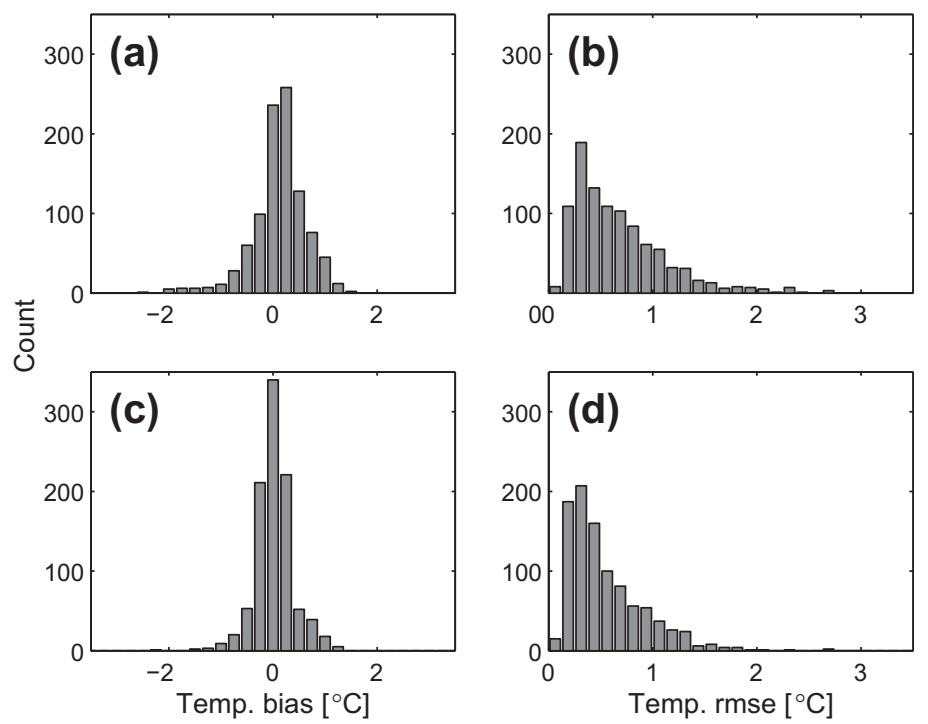

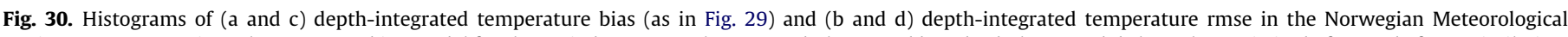

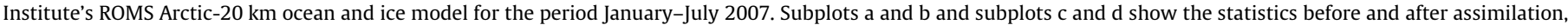
respectively.

observations are brought together using data assimilation techniques to provide the most realistic representation of "now", from which to start forecasting into the future. Therefore, one of our objectives is to develop suitable data assimilation schemes for operational ocean and ice models.

Sea Surface Temperature (SST), Sea Surface Height (SSH) and Sea Ice Concentration (SIC) have been reliably measured by operational satellites for the last decade or so. Although some challenges remain, these sources of information constitute the core data for coupled ocean and ice modeling. Satellite products have many advantages, including broad spatial coverage and rapid repetition rates, especially at high latitudes with polar orbiting platforms. Driven by the meteorology community, it is safe to assume that operational satellites will continue to be flown in the future, thus assuring regular access to these core data. The space missions also benefit from international cooperation, both for the operation of the satellites via space agencies like NASA, ESA and EUMETSAT and for the value-adding operational processing chains. The EUMETSAT Ocean and Sea Ice Satellite Application Facility (OSI SAF - www.osi-saf.org), for example, is a European consortium for near-real-time processing of state-of-the-art sea surface temperature, winds, radiative fluxes and sea ice products which are delivered to meteorological agencies and to the scientific community at large.

Although satellite observations have high spatial coverage and high repetition rates, satellites cannot see through the sea surface and are thus unable to constrain the three-dimensional domain of an ocean model. On a large scale, ocean circulation depends on weak gradients in ocean density. Therefore, knowing the surface heat fluxes, the density field and the sub-surface turbulent mixing of water masses is of particular importance in ocean forecasting. Since many sub-surface phenomena have no, or very subtle, surface signatures (e.g. the mixing induced by internal waves breaking over topography), a practical data assimilation system should include sub-surface observations in addition to satellite data.

There are four types of sub-surface ocean measurements that report in near real time in the High North and therefore can be used to initialize ocean forecasts: (1) ARGO profiling buoys; (2) ice-tethered profiling buoys; (3) autonomous vehicles such as the Seaglider, and (4) animal-borne platforms. ARGO is a global array of roughly 3000 free-drifting profiling floats that measure the temperature and salinity of the upper $2000 \mathrm{~m}$ of the ocean. Deployments of the ARGO floats began in 2000 and the array has grown to be a major component of the ocean observing system. It allows 
Table A1

Contact information for the individual activities of the projects.

\begin{tabular}{|c|c|c|c|c|}
\hline Activity & Contact person(s) & Affiliation & E-mail address & Comments \\
\hline Data management & Øystein Godøy & met.no & oystein.godoy@met.no & \\
\hline Transport sections & $\begin{array}{l}\text { Bogi Hansen } \\
\text { Bee Berx } \\
\text { Kjell Arild Orvik } \\
\text { Frode Høydalsvik } \\
\text { Øystein Skagseth } \\
\text { Agnieszka Beszczynska-Möller } \\
\text { Edmond Hansen, Laura de Steur }\end{array}$ & $\begin{array}{l}\text { FFL } \\
\text { MS } \\
\text { UiB } \\
\text { met.no } \\
\text { IMR } \\
\text { AWI } \\
\text { NPI }\end{array}$ & $\begin{array}{l}\text { bogihan@frs.fo } \\
\text { b.berx@marlab.ac.uk } \\
\text { Kjell.Orvik@gfi.uib.no } \\
\text { frode.hoydalsvik@met.no } \\
\text { oystein.skagseth@imr.no } \\
\text { Agnieszka.Beszczynska-Moeller@awi.de } \\
\text { edmond.hansen@npolar.no, desteur@npolar.no }\end{array}$ & $\begin{array}{l}\text { Sections (a) and (i) } \\
\text { Section (b) } \\
\text { Section (c) } \\
\text { Section (d) } \\
\text { Section (e) } \\
\text { Sections (f) and (g) } \\
\text { Sections (g) and (h) }\end{array}$ \\
\hline $\begin{array}{l}\text { RAFOS floats } \\
\text { Seaglider }\end{array}$ & $\begin{array}{l}\text { Henrik Søiland } \\
\text { Frode Høydalsvik } \\
\text { Craig Lee }\end{array}$ & $\begin{array}{l}\text { IMR } \\
\text { met.no } \\
\text { APL }\end{array}$ & $\begin{array}{l}\text { henrik.soiland@imr.no } \\
\text { frode.hoydalsvik@met.no } \\
\text { craig@apl.washington.edu }\end{array}$ & \\
\hline Drifters (Poleward project) & $\begin{array}{l}\text { Inga Koszalka } \\
\text { Maria Andersson } \\
\text { Joseph LaCasce }\end{array}$ & $\begin{array}{l}\mathrm{UiO} \\
\mathrm{UiB} \\
\mathrm{UiO}\end{array}$ & $\begin{array}{l}\text { inga.koszalka@geo.uio.no } \\
\text { Maria.Andersson@gfi.uib.no } \\
\text { j.h.lacasce@geo.uio.no }\end{array}$ & \\
\hline Fram Strait moorings & $\begin{array}{l}\text { Laura de Steur } \\
\text { Edmond Hansen } \\
\text { Agnieszka Beszczynska-Möller }\end{array}$ & $\begin{array}{l}\text { NPI } \\
\text { NPI } \\
\text { AWI }\end{array}$ & $\begin{array}{l}\text { desteur@npolar.no } \\
\text { edmond.hansen@npolar.no } \\
\text { Agnieszka.Beszczynska-Moeller@awi.de }\end{array}$ & \\
\hline Fram Strait heat loss studies & $\begin{array}{l}\text { Sigurd Teigen } \\
\text { Frank Nilsen }\end{array}$ & $\begin{array}{l}\text { Unis } \\
\text { Unis }\end{array}$ & $\begin{array}{l}\text { sigurdt@unis.no } \\
\text { frank.nilsen@unis.no }\end{array}$ & \\
\hline Seals (MEOP project) & $\begin{array}{l}\text { Paul Dodd } \\
\text { Kit Kovacs } \\
\text { Christian Lydersen }\end{array}$ & $\begin{array}{l}\text { NPI } \\
\text { NPI } \\
\text { NPI }\end{array}$ & $\begin{array}{l}\text { paul.dodd@npolar.no } \\
\text { kit.kovacs@npolar.no } \\
\text { christian.lydersen@npolar.no }\end{array}$ & Incl. tracer data $\left(\delta^{18} \mathrm{O}\right)$ \\
\hline Sea ice observations & $\begin{array}{l}\text { Steve Hudson } \\
\text { Sebastian Gerland } \\
\text { Marcel Nicolaus }\end{array}$ & $\begin{array}{l}\text { NPI } \\
\text { NPI } \\
\text { AWI }\end{array}$ & $\begin{array}{l}\text { hudson@npolar.no } \\
\text { sebastian.gerland@npolar.no } \\
\text { marcel.nicolaus@awi.de }\end{array}$ & \\
\hline Climate modeling & $\begin{array}{l}\text { Jens Debernard } \\
\text { Morten Køltzow }\end{array}$ & $\begin{array}{l}\text { met.no } \\
\text { met.no }\end{array}$ & $\begin{array}{l}\text { jens.debernard@met.no } \\
\text { morten.koltzow@met.no }\end{array}$ & \\
\hline Ocean and ice forecasting & $\begin{array}{l}\text { Kai Christensen } \\
\text { Pål Erik Isachsen } \\
\text { Ann Kristin Sperrevik } \\
\text { Thomas Lavergne }\end{array}$ & $\begin{array}{l}\text { met.no } \\
\text { met.no } \\
\text { met.no } \\
\text { met.no }\end{array}$ & $\begin{array}{l}\text { kai.h.christensen@met.no } \\
\text { pal.e.isachsen@met.no } \\
\text { ann.k.sperrevik@met.no } \\
\text { thomas.lavergne@met.no }\end{array}$ & \\
\hline Biology & $\begin{array}{l}\text { Marit Reigstad } \\
\text { Christian Wexels Riser } \\
\text { Lena Seuthe } \\
\text { Camilla Svensen }\end{array}$ & $\begin{array}{l}\text { UiT } \\
\text { UiT } \\
\text { UiT } \\
\text { UiT }\end{array}$ & $\begin{array}{l}\text { marit.reigstad@uit.no } \\
\text { christian.riser@uit.no } \\
\text { lena.seuthe@uit.no } \\
\text { camilla.svensen@uit.noss }\end{array}$ & \\
\hline
\end{tabular}

$\mathrm{APL}=$ Applied Physics Laboratory, University of Washington

AWI = Alfred Wegener Institute for Polar and Marine Research.

$\mathrm{FFL}=$ Faroese Fisheries Laboratory.

IMR = Institute of Marine Research

met.no = Norwegian Meteorological Institute.

MS = Marine Scotland.

NPI = Norwegian Polar Institute.

$\mathrm{UiB}=$ University of Bergen.

$\mathrm{UiO}=$ University of Oslo.

UiT = University of Tromsø, Norwegian College of Fishery Science.

Unis = University Centre in Svalbard.

continuous monitoring of the temperature, salinity, and velocity of the upper ocean, with all data being relayed and made publicly available within hours after collection (see http://wo.jcommops.org/cgi-bin/WebObjects/Argo). Since 2001, when the first ARGO buoy was deployed in the Nordic Seas, roughly 5000 CTD profiles have been obtained in our region. Ice-tethered profilers (ITPs) (see e.g. http://www.whoi.edu/page.do?pid=20756), repeatedly sample the properties of the ice-covered Arctic Ocean at high vertical resolution over periods up to 3 years. The system consists of a small surface capsule that sits atop an ice floe and supports a plastic-jacketed wire rope tether that extends through the ice and down into the ocean, ending with a weight (intended to keep the wire vertical). A cylindrical underwater instrument is mounted on this tether and cycles vertically along it, carrying oceanographic sensors through the water column. Water-property data are relayed from the ITP to shore in near real time. Since 2004, roughly 20,000 profiles have been obtained in the Arctic Ocean. And as we saw in Section 3.7, seals have provided roughly 7000 CTD profiles during IPY. Therefore, there is a much larger potential for using near-real-time sub-surface information in ocean forecasts today compared to only 5-10 years ago.

A system for assimilating in situ profiles has been developed during iAOOS-Norway. ${ }^{1}$ This assimilation scheme is currently being tested based on a 10-year hindcast simulation (1999-2009), from which model error statistics have been collected. A comparison of runs with and without assimilation of ARGO profiles for the period

\footnotetext{
1 The observations are first interpolated to the ocean model's vertical layers using a BLUE (Best Linear Un-biased Estimate) analysis scheme. The vertical correlations are modeled using second-order auto-regressive functions (e.g. Cummings, 2005), resulting in a complete (synthetic) vertical profile. A loop is then made over all horizontal layers in the model, as well as over all the observations made within the assimilation window (currently ten days). For each profile, an analysis increment is distributed to the model grid points within a prescribed horizontal distance from the observation point. This distance is proportional to the horizontal correlation length scales calculated from a model historical ensemble. The correlation length scales are anisotropic, e.g. with larger values along isobaths than across, and the assimilation algorithm will distribute the analysis increments accordingly. An incremental analysis update method is used to reduce spurious high frequency oscillations caused by the assimilation scheme (e.g. Ourmières et al., 2006).
} 
January through July 2007 is presented: Fig. 29 shows maps of the depth-integrated temperature bias before and after assimilation, whereas Fig. 30 shows histograms of this bias and the root mean square error (rmse) before and after assimilation. Both these measures of model-observation differences are reduced which indicates that the assimilation system is able to make use of the observations and to make persistent bias corrections in the model hydrography. Thus, these preliminary results show that in situ data have a significant positive impact on general ocean-circulation models.

When fully developed this system will become part of the operational ocean- and ice-forecasting system at the Norwegian Meteorological Institute, and will take advantage not only of ARGO data but of other sub-surface real-time observations as well.

\section{Concluding remarks}

This paper has presented a status report of the research activities of the Norwegian IPY projects iAOOS-Norway, POLEWARD and MEOP at the official end of the IPY. Highlights of the research include: a quantification of the Meridional Overturning Circulation in the Nordic Seas ("the loop") in thermal space, based on a set of up to 15-year-long series of current measurements; a detailed map of the surface circulation as well as characterization of the eddy dispersion based on drifter data; transport monitoring of Atlantic Water using Seagliders; a view of the water mass exchanges in the Norwegian Atlantic Current from both Eulerian and Lagrangian data; an integrated physical-biological view of the ice-influenced ecosystem in the East Greenland Current, showing for instance that nutrient-limited primary production is a consequence of decreasing ice cover for larger regions of the Arctic Ocean. Our sea ice studies show that the albedo of snow on ice is lower when snow cover is thinner and suggest that reductions in sea ice thickness, even without changes in sea ice extent, will have a significant impact on the arctic atmosphere. We present up-todate freshwater transport estimates for the East Greenland Current in the Fram Strait and the first map of the annual cycle of freshwater layer thickness in the East Greenland Current along the east coast of Greenland, from data obtained by seal-borne CTDs as the animals criss-crossed the Nordic Seas. We have taken advantage of the real-time transmission of some of these platforms, and demonstrate the use of ice-tethered profilers in validating satellite products of sea ice motion, as well as the use of Seagliders in validating ocean forecasts, and we present a sea ice drift product, significantly improved both in space and time, for use in operational ice-forecasting applications.

During the International Polar Year, it has become increasingly obvious that we need to prepare for a new era in the Arctic. Commercial activities will become ever more attractive as the sea ice retreats, and scientists are not able to provide answers to all the new questions that arise concerning what is required to "operate safely and sustainably" in the High North. At the same time, climate is a global, not a regional issue, making changes in the Arctic

Table A2

Transport (Sv) in temperature classes. Contact information: see Table A1.

\begin{tabular}{|c|c|c|c|c|c|c|c|c|c|}
\hline $\begin{array}{l}\text { Temperature classes } \\
\left({ }^{\circ} \mathrm{C}\right)\end{array}$ & $\begin{array}{l}\text { North of } \\
\text { Faroes }^{\mathrm{a}}\end{array}$ & $\begin{array}{l}\text { Faroe- } \\
\text { Shetland }^{\text {b }}\end{array}$ & $\begin{array}{l}\text { Svinøy } \\
\text { East }^{\mathrm{c}}\end{array}$ & $\begin{array}{l}\text { Svinøy } \\
\text { West }^{\mathrm{d}}\end{array}$ & $\begin{array}{l}\text { Barents Sea } \\
\text { Entrance }^{\mathrm{e}}\end{array}$ & $\begin{array}{l}\text { Fram Strait } \\
\text { East }^{\mathrm{f}}\end{array}$ & $\begin{array}{l}\text { Fram } \\
\text { Strait }^{\mathrm{g}}\end{array}$ & $\begin{array}{l}\text { Fram Strait } \\
\text { West }^{\text {h }}\end{array}$ & $\begin{array}{l}\text { Faroe Bank } \\
\text { Channel }^{\mathrm{i}}\end{array}$ \\
\hline-2.0 to -1.5 & 0.00 & 0.00 & 0.00 & 0.00 & 0.00 & 0.00 & -0.21 & -0.21 & -1.18 \\
\hline-1.5 to -1.0 & 0.00 & 0.00 & 0.00 & 0.00 & 0.00 & 0.00 & -0.29 & -0.29 & \\
\hline-1.0 to -0.5 & 0.02 & 0.00 & 0.00 & 0.00 & 0.00 & 1.44 & -1.51 & -2.14 & \\
\hline-0.5 to 0.0 & 0.06 & 0.00 & 0.00 & 0.00 & 0.00 & 0.65 & -1.15 & -1.58 & \\
\hline $0.0-0.5$ & 0.10 & 0.00 & 0.06 & 0.00 & 0.00 & 0.29 & -0.83 & -1.09 & -0.18 \\
\hline $0.5-1.0$ & 0.09 & 0.00 & 0.07 & 0.00 & 0.00 & 0.26 & -0.54 & -0.79 & \\
\hline $1.0-1.5$ & 0.10 & -0.01 & 0.08 & 0.00 & 0.00 & 0.30 & -0.48 & -0.78 & -0.17 \\
\hline $1.5-2.0$ & 0.10 & -0.01 & 0.08 & 0.00 & 0.00 & 0.36 & -0.23 & -0.61 & \\
\hline $2.0-2.5$ & 0.12 & -0.01 & 0.09 & 0.00 & -0.09 & 0.46 & 0.20 & -0.27 & -0.17 \\
\hline $2.5-3.0$ & 0.14 & -0.01 & 0.09 & 0.00 & -0.17 & 0.66 & 0.59 & -0.03 & \\
\hline $3.0-3.5$ & 0.15 & -0.01 & 0.07 & 0.00 & -0.07 & 0.75 & 0.75 & -0.01 & -0.15 \\
\hline $3.5-4.0$ & 0.16 & -0.01 & 0.08 & 0.03 & -0.04 & 0.63 & 0.64 & 0.01 & \\
\hline $4.0-4.5$ & 0.17 & -0.01 & 0.11 & 0.26 & 0.01 & 0.50 & 0.51 & 0.01 & -0.15 \\
\hline $4.5-5.0$ & 0.20 & 0.00 & 0.12 & 0.43 & 0.07 & 0.25 & 0.24 & 0.00 & \\
\hline $5.0-5.5$ & 0.24 & 0.01 & 0.12 & 0.42 & 0.18 & 0.13 & 0.13 & 0.00 & -0.13 \\
\hline $5.5-6.0$ & 0.30 & 0.01 & 0.12 & 0.52 & 0.33 & 0.07 & 0.07 & 0.00 & \\
\hline $6.0-6.5$ & 0.37 & 0.02 & 0.45 & 0.54 & 0.53 & 0.03 & 0.03 & 0.00 & -0.05 \\
\hline $6.5-7.0$ & 0.45 & 0.03 & 0.42 & 0.73 & 0.23 & 0.01 & 0.01 & 0.00 & \\
\hline $7.0-7.5$ & 0.63 & 0.04 & 0.48 & 1.15 & 0.14 & 0.00 & 0.00 & 0.00 & \\
\hline $7.5-8.0$ & 0.49 & -0.03 & 0.70 & 1.33 & 0.13 & 0.00 & 0.00 & 0.00 & \\
\hline $8.0-8.5$ & 0.44 & 0.25 & 0.72 & 0.65 & 0.00 & 0.00 & 0.00 & 0.00 & \\
\hline $8.5-9.0$ & 0.40 & 0.64 & 0.86 & 0.48 & 0.00 & 0.00 & 0.00 & 0.00 & \\
\hline $9.0-9.5$ & 0.21 & 0.80 & 0.52 & 0.25 & 0.00 & 0.00 & 0.00 & 0.00 & \\
\hline $9.5-10.0$ & 0.12 & 1.37 & 0.00 & 0.10 & 0.00 & 0.00 & 0.00 & 0.00 & \\
\hline $10.0-10.5$ & 0.07 & 0.76 & 0.00 & 0.05 & 0.00 & 0.00 & 0.00 & 0.00 & \\
\hline $10.5-11.0$ & 0.02 & 0.19 & 0.00 & 0.04 & 0.00 & 0.00 & 0.00 & 0.00 & \\
\hline $11.0-11.5$ & 0.00 & 0.00 & 0.00 & 0.03 & 0.00 & 0.00 & 0.00 & 0.00 & \\
\hline $11.5-12.0$ & 0.00 & 0.00 & 0.00 & 0.03 & 0.00 & 0.00 & 0.00 & 0.00 & \\
\hline $12.0-12.5$ & 0.00 & 0.00 & 0.00 & 0.06 & 0.00 & 0.00 & 0.00 & 0.00 & \\
\hline $12.5-13.0$ & 0.00 & 0.00 & 0.00 & 0.01 & 0.00 & 0.00 & 0.00 & 0.00 & \\
\hline Sum & 5.17 & 4.03 & 5.21 & 7.11 & 1.26 & 6.78 & -2.08 & -7.80 & -2.18 \\
\hline
\end{tabular}

a North of the Faroe Islands, at $6^{\circ} 05 \mathrm{~W}$, between $62^{\circ} 25 \mathrm{~N}$ and $63^{\circ} 35 \mathrm{~N}$, from the surface down to $600 \mathrm{~m}$, for the years $1997-2001$.

b Faroe-Shetland Channel, between $61^{\circ} 16 \mathrm{~N}, 06^{\circ} 38 \mathrm{~W}$ and $60^{\circ} 10 \mathrm{~N}, 03^{\circ} 44 \mathrm{~W}$, average for the years $1994-2008$.

c Svinøy Section, eastern branch, between $62.76^{\circ} \mathrm{N}, 4.33^{\circ} \mathrm{E}$ and $63.15^{\circ} \mathrm{N}, 3.55^{\circ} \mathrm{E}$, average for the years $1995-1999$.

d Svinøy Section, western branch, between $63.29^{\circ} \mathrm{N}, 3.30^{\circ} \mathrm{E}$ and $65.1^{\circ} \mathrm{N}, 1^{\circ} \mathrm{W}$, Seaglider results from nine transects in 2009 , transport for water with salinity $>35$.

e Barents Sea Opening, between $71.25^{\circ} \mathrm{N}, 19.80^{\circ} \mathrm{E}$ and $74^{\circ} \mathrm{N}, 19.20^{\circ} \mathrm{E}$, average for the years $2003-2005$.

${ }^{\mathrm{f}}$ Fram Strait, between $5^{\circ} \mathrm{E}$ and Spitsbergen, average for the years 2002-2008.

g Fram Strait, average for the years 2002-2008.

h Fram Strait, between the Greenland shelf and $0^{\circ} \mathrm{E}$, average for the years 2002-2008.

${ }^{i}$ Faroe Bank Channel (from Hansen and Østerhus, 2007), average for the years 1995-2005. 
of worldwide significance. To understand and minimize the impacts of human activities, we need continued monitoring and highly interdisciplinary research. iAOOS-Norway, POLEWARD and MEOP have, together with a number of other IPY projects, contributed to the pilot phase of what could be a long-term Arctic Observing (and Analysis) System.

It is our opinion that real-time monitoring of the Arctic Ocean sub-surface should be a component of a sustained Observing System. The near-real-time monitoring of the Arctic Ocean that has been possible during the IPY, has allowed us more insights and shorter response time in our research than would otherwise have been possible. It is also our opinion that the countries bordering on the Arctic should collectively sponsor a network of (a) profiling buoys (ARGO-type in open ocean; ITP-type in ice-covered ocean as well as animal platforms, which traverse both ice covered and open ocean) to monitor changes in the heat and freshwater content of the Arctic Mediterranean; (b) remotely controlled autonomous vehicles and bottom-anchored current meters to monitor the strength of the ocean currents along the continental slopes (such as at Svinøy) and in ocean gateways (such as in the Fram Strait); and (c) repeat hydrographic sections to further extend long time series and (d) a set of interdisciplinary oceanic, or Earth System, bottom-anchored "super-sites" in each of the ocean basins, which make concurrent observations of key climate variables (defined by international standards) and key physical, biological and biogeochemical variables, also beneath the 1000-2000 m lower depth limit of today's autonomous platforms.

\section{Acknowledgements}

The iAOOS-Norway, POLEWARD and MEOP teams would like to thank the Norwegian Research Council for its support through the International Polar Year and NORKLIMA programs (grant numbers $176096 / \mathrm{S} 30,178559 / \mathrm{S} 30$ and 176477). The projects are described on the web at www.iaoos.no and www.meop.no. We would like to thank our home institutes and universities (the Norwegian Meteorological Institute, the Norwegian Polar Institute, the Institute of Marine Research, the University Centre in Svalbard, and the Universities of Oslo, Bergen and Tromsø) for their generous support of these projects. "EM-Bird" ice thickness measurements were supported through funding from iAOOS and the European Space Agency (ESA) along with the Norwegian Space Center (PRODEX program). Fieldwork was also supported through the EU Integrated Project DAMOCLES. We would like to thank the Norwegian Coast Guard for its support of IPY in general, for its participation in iAOOS-Norway in the East Greenland Current (KV Svalbard) and for numerous Seaglider deployments and rescue operations. Finally, we would like to thank Gudmund Dalsbø for patient administration of iAOOS-Norway and POLEWARD, and for his editorial help in producing this paper.

\section{Appendix A}

\section{See Tables A1 and A2.}

\section{References}

Aagaard, K., Carmack, E.C., 1989. The role of sea ice and other fresh water in the Arctic circulation. Journal of Geophysical Research 94 (C10), 14485-14498.

Andersson, M., Orvik, K.A., LaCasce, J.H., Koszalka, I., Mauritzen, C., submitted for publication. Variability of the Norwegian Atlantic Current and associated eddy field from surface drifters. Journal of Geophysical Research.

Banks, H., Keen, A., Ridley, J., Gregory, J., McLaren, A., 2006. Sea ice modelling for climate applications. In: ECMWF Seminar on Polar Meteorology (September 2006). European Centre for Medium-Range Weather Forecasts, Reading, pp. 143-152, <http://www.ecmwf.int/publications/library/ecpublications/_pdf/ seminar/2006/Banks.pdf.>
Bitz, C.M., Holland, M.M., Weaver, A.J., Eby, M., 2001. Simulating the ice-thickness distribution in a coupled climate model. Journal of Geophysical Research 106 (C2), 2441-2463.

Björk, G., Söderkvist, J., 2002. Dependence of the Arctic Ocean ice thickness distribution on the poleward energy flux in the atmosphere. Journal of Geophysical Research 107 (C10), 3173. doi:10.1029/2000JC000723.

Brandt, R.E., Warren, S.G., Worby, A.P., Grenfell, T.C., 2005. Surface Albedo of the Antarctic Sea ice zone. Journal of Climate 18,3606-3622. doi:10.1175/JCLI3489.1.

Christensen, J.H., Christensen, O.B., Lopez, P., van Meijgaard, E., Botzet, M., 1996. The HIRHAM4 Regional Atmospheric Climate Model. DMI Scientific Report 1996:4. Danish Meteorological Institute, Copenhagen, <http://www.dmi.dk/dmi/sr964.pdf>.

Comiso, J.C., Parkinson, C.L., Gersten, R., Stock, L., 2008. Accelerated decline in the Arctic sea ice cover. Geophysical Research Letters 35, L01703. doi:10.1029/ 2007GL031972.

Cottier, F.R., Nilsen, F., Inall, M.E., Gerland, S., Tverberg, V., Svendsen, H., 2007. Wintertime warming of an Arctic shelf in response to large-scale atmospheric circulation. Geophysical Research Letters 34, L10607. doi:10.1029/ 2007GL029948.

Cummings, J.A., 2005. Operational multivariate ocean data assimilation. Quarterly Journal of the Royal Meteorological Society, Part C 131, 3583-3604.

Curry, J.A., Schramm, J.L., Perovich, D.K., Pinto, J.O., 2001. Applications of SHEBA/ FIRE data to evaluation of snow/ice albedo parameterizations. Journal of Geophysical Research 106 (D14), 15345-15355. doi:10.1029/2000JD900311.

de Steur, L., Hansen, E., Gerdes, R., Karcher, M., Fahrbach, E., Holfort, J., 2009. Freshwater fluxes in the East Greenland Current: a decade of observations. Geophysical Research Letters 36, L23611. doi:10.1029/2009gl041278.

Dethloff, K., Rinke, A., Benkel, A., Køltzow, M., Sokolova, E., Kumar Saha, S., Handorf, D., Dorn, W., Rockel, B., von Storch, H., Haugen, J.E., Røed, L.P., Roeckner, E., Christensen, J.H., Stendel, M., 2006. A dynamical link between the Arctic and the global climate system. Geophysical Research Letters 33, L03703. doi:10.1029/ 2005 GL025245.

Dickson, R.R., Dye, S., Jónsson, S., Köhl, A., Macrander, A., Marnela, M., Meincke, J., Olsen, S., Rudels, B., Valdimarsson, H., Voet, G., 2008. The overflow flux west of Iceland. Variability, origins and forcing. In: Dickson, R.R., Meincke, J., Rhines, P. (Eds.), Arctic-Subarctic Ocean Fluxes. Defining the Role of the Northern Seas in Climate. Springer, Dordrecht, pp. 443-474.

Eicken, H., 2003. From the microscopic, to the macroscopic, to the regional scale: growth, microstructure and properties of sea ice. In: Thomas, D.N., Dieckmann, G.S. (Eds.), Sea Ice - An Introduction to its Physics, Chemistry, Biology and Geology. Blackwell Science Ltd., Oxford, pp. 22-81.

Ellingsen, I.H., Dalpadado, P., Slagstad, D., Loeng, H., 2008. Impact of climatic change on the biological production in the Barents Sea. Climatic Change 87, 155-175.

Eriksen, C.C., Osse, T.J., Light, R.D., Wen, T., Lehman, T.W., Sabin, P.L., Ballard, J.W., Chiodi, A.M., 2001. Seaglider: a long-range autonomous underwater vehicle for oceanographic research. IEEE Journal of Oceanic Engineering 26, 424-436.

Ezraty, R., Girard-Ardhuin, F., Piollé, J.-F., 2007. Sea Ice Drift in the Central Arctic Estimated from SeaWinds/QuikSCAT Backscatter Maps. User's Manual. Laboratoire d'Océanographie Spatiale (Département d'Océanographie Physique et Spatiale), IFREMER, Brest.

Falk-Petersen, S., Mayzaud, P., Kattner, G., Sargent, J.R., 2009. Lipids and life strategy of Arctic Calanus. Marine Biology Research 5, 18-39.

Fer, I., Skogseth, R., Geyer, F., 2010. Internal waves and mixing in the marginal ice zone near the Yermak Plateau. Journal of Physical Oceanography 40 (7), 16131630. doi:10.1175/2010JPO4371.1.

Furevik, T., 1998. On the Atlantic inflow in the Nordic Seas: bifurcation and variability. Dr. Scient thesis. University of Bergen, Bergen.

Furevik, T., 2001. Annual and interannual variability of Atlantic Water temperatures in the Norwegian and Barents Seas: 1980-1996. Deep-Sea Research Part I 48, 383-404.

Gascard, J.-C., Raisbeck, G., Sequeira, S., Yiou, F., Mork, K.A., 2004. The Norwegian Atlantic Current in the Lofoten basin inferred from hydrological and tracer data (129I) and its interaction with the Norwegian Coastal Current. Geophysical Research Letters 31, L01308. doi:10.1029/2003GL018303.

Gascard, J.-C., Festy, J., le Goff, H., Weber, M., Bruemmer, B., Offermann, M., Doble, M., Wadhams, P., Forsberg, R., Hanson, S., Skourup, H., Gerland, S., Nicolaus, M., Metaxian, J.-P., Grangeon, J., Haapala, J., Rinne, E., Haas, C., Heygster, G., Jakobson, E., Palo, T., Wilkinson, J., Kaleschke, L., Claffey, K., Elder, B., Bottenheim, J., 2008. Exploring Arctic transpolar drift during dramatic sea ice retreat. Eos Transactions, American Geophysical Union 89. doi:10.1029/2008EO0300.

Gascard, J.-C., Mork, K.A., 2008. Climatic importance of large-scale and mesoscale circulation in the Lofoten Basin deduced from lagrangian observations. In: Dickson, R.R., Meincke, J., Rhines, P. (Eds.), Arctic-Subarctic Ocean Fluxes: Defining the Role of the Northern Seas in Climate. Springer, Dordrecht, pp. 131143.

Gerland, S., Haas, C., Hall, R., Holfort, J., Hansen, E., Løyning, T.B., Renner, A., 2006. Spring sea ice thickness in the western Fram Strait: preliminary results. In: Wadhams, P., Amanatidis, G. (Eds.), Arctic Sea Ice Thickness: Past, Present and Future (Climate Change and Natural Hazards Series 10). European Commission, Brussels, pp. 158-164.

Giles, K.A., Laxon, S.W., Ridout, A.L., 2008. Circumpolar thinning of Arctic sea ice following the 2007 record ice extent minimum. Geophysical Research Letters 35, L22502. doi:10.1029/2008GL035710.

Gradinger, R.R., Baumann, M.E.M., 1991. Distribution of phytoplankton communities in relation to the large-scale hydrographical regime in the Fram Strait. Marine Biology 111, 311-321. 
Grenfell, T.C., 1991. A radiative transfer model for sea ice with vertical structure variations. Journal of Geophysical Research 96 (C9), 16991-17001. doi:10.1029/ 91JC01595.

Haas, C., Lobach, J., Hendricks, S., Rabenstein, L., Pfaffling, A., 2009. Helicopter-borne measurements of sea ice thickness, using a small and lightweight, digital EM system. Journal of Applied Geophysics 67, 234-241. doi:10.1016/ j.jappgeo.2008.05.005

Hansen, B., Østerhus, S., 2007. Faroe bank channel overflow 1995-2005. Progress in Oceanography $75,817-856$.

Hátún, H., Sandø, A.B., Drange, H., Hansen, B., Valdimarsson, H., 2005. Influence of the Atlantic subpolar gyre on the thermohaline circulation. Science 309, 1841-1844.

Hirche, H.-J., Baumann, M.E.M., Kattner, G., Gradinger, R., 1991. Plankton distribution and the impact of copepod grazing on primary production in Fram Strait, Greenland Sea. Journal of Marine Systems 2, 477-494.

Hirche, H.-J., Kosobokova, K., 2007. Distribution of Calanus finmarchicus in the northern North Atlantic and Arctic Ocean. Expatriation and potential colonization. Deep-Sea Research Part II: Topical Studies in Oceanography 54, 2729-2747.

Hop, H., Falk-Petersen, S., Svendsen, H., Kwasniewski, S., Pavlov, V., Pavlova, O. Søreide, J.E., 2006. Physical and biological characteristics of the pelagic system across Fram Strait to Kongsfjorden. Progress in Oceanography 71, 182-231.

Huang, B., Lan, W., Cao, Z., Dai, M., Huang, L., Jiao, N., Hong, H., 2008. Spatial and temporal distribution of nanoflagellates in the northern South China Sea. Hydrobiologia 605, 143-157.

Ingvaldsen, R., Loeng, H., Asplin, L., 2002. Variability in the Atlantic inflow to the Barents Sea based on a one-year time series from morred current meters. Continental Shelf Research 22, 505-519.

Ingvaldsen, R.B., Asplin, L., Loeng, H., 2004. Velocity field of the western entrance to the Barents Sea. Journal of Geophysical Research 109, C03021. doi:10.1029/ 2003JC001811.

Isachsen, P.E., LaCasce, J.H., Mauritzen, C., Häkkinen, S., 2003. Wind-driven variability of the large-scale recirculating flow in the Nordic Seas and Arctic Ocean. Journal of Physical Oceanography 33, 2534-2550.

Isachsen, P.E., Mauritzen, C., Svendsen, H., 2007. Dense water formation in the Nordic Seas diagnosed from sea surface buoyancy fluxes. Deep-Sea Research Part I 54, 22-41.

Jónsson, S., Briem, J., 2003. Flow of Atlantic water west of Iceland and onto the north Icelandic shelf. ICES Marine Science Symposia 219, 326-328.

Køltzow, M., 2007. The effect of a new snow and sea ice albedo scheme on regional climate model simulations. Journal of Geophysical Research 112, D07110. doi:10.1029/2006JD007693.

Koszalka, I., LaCasce, J.H., Orvik, K.A., 2009. Relative dispersion in the Nordic Seas. Journal of Marine Research 67, 411-433.

Koszalka, I., LaCasce, J.H., Andersson, M., Orvik, K.A., Mauritzen, C., accepted for publication. Surface circulation in the Nordic Seas from clustered drifters. DeepSea Research.

Kowalik, Z., Proshutinsky, A.Y., 1995. Topographic enhancement of tidal motion in the western Barents Sea. Journal of Geophysical Research 100 (C2), 2613-2637.

Kwok, R., Cunningham, G.F., 2008. ICESat over Arctic sea ice: estimation of snow depth and ice thickness. Journal of Geophysical Research 113, C08010. doi:10.1029/2008JC004753.

LaCasce, J.H., 2004. Diffusivity and viscosity dependence in the linear thermocline. Journal of Marine Research 62, 743-769.

LaCasce, J.H., 2005. Eulerian and Lagrangian velocity distributions in the North Atlantic. Journal of Physical Oceanography 35, 2327-2336.

Lavergne, T., 2010. Validation and Monitoring of the OSI SAF Low Resolution Sea Ice Drift Product - v2. Technical Report SAF/OSI/CDOP/met.no/T\&V/RP/131, EUMETSAT OSI SAF - Ocean and Sea Ice Sattelite Application Facility, March 2010, <ftp://saf.met.no/docs/REPORT_OSISAF_LRSeaIceDrift_Validation.pdf>.

Lavergne, T., Eastwood, S., Teffah, Z., Schyberg, H., Breivik, L.-A., 2010. Sea ice motion from low resolution satellite sensors: an alternative method and its validation in the Arctic. Journal of Geophysical Research Oceans 115, C10032. doi:10.1029/ 2009JC005958.

Laxon, S., Peacock, N., Smith, D., 2003. High interannual variability of sea ice thickness in the Arctic region. Nature 425, 947-950.

Levinsen, H., Nielsen, T.G., 2002. The trophic role of marine pelagic ciliates and heterotrophic dinoflagellates in arctic and temperate coastal ecosystems: a cross-latitude comparison. Limnology and Oceanography 47, 427-439.

Li, W.K.W., McLaughlin, F.A., Lovejoy, C., Carmack, E.C., 2009. Smallest Algae thrive as the Arctic Ocean freshens. Science 326, 539.

Lindsay, R.W., Zhang, J., 2005. The thinning of Arctic sea ice, 1988-2003: have we passed a tipping point? Journal of Climate 18, 4879-4894.

Liu, J., Zhang, Z., Inoue, J., Horton, R.M., 2007. Evaluation of snow/ice albedo parameterizations and their impacts on sea ice simulations. International Journal of Climatology 27, 81-91.

Marotzke, J., 1997. Boundary mixing and the dynamics of three-dimensional thermohaline circulations. Journal of Physical Oceanography 27, 1713-1728.

Marshall, S.E., Warren, S.G., 1986. Parameterization of Snow Albedo for climate models. In: Kukla, G., Barry, R.G., Hecht, A., Wiesnet, D. (Eds.), Snow Watch '85. Glaciological Data (Report GD-18). World Data Center A for Glaciology (Snow and Ice), Boulder, pp. 215-223.

Marshall, S., Oglesby, R.J., 1994. An improved snow hydrology for GCMs. Part 1: snow cover fraction, albedo, grain size, and age. Climate Dynamics 10, 21-37.

Maslanik, J.A., Fowler, C., Stroeve, J., Drobot, S., Zwally, J., Yi, D., Emery, W., 2007. A younger, thinner Arctic ice cover: increased potential for rapid, extensive seaice loss. Geophysical Research Letters 34, L24501. doi:10.1029/2007GL032043.
Mauritzen, C., 1996a. Production of dense overflow waters feeding the North Atlantic across the Greenland-Scotland Ridge. Part 1: evidence for a revised circulation scheme. Deep-Sea Research Part I 43, 769-806.

Mauritzen, C., 1996b. Production of dense overflow waters feeding the North Atlantic across the Greenland-Scotland Ridge. Part 2: an inverse model. DeepSea Research Part I 43, 807-835.

McClatchey, R.A., Fenn, R.W., Selby, J.E.A., Volz, F.E., Garing, J.S., 1972. Optica Properties of the Atmosphere, 3rd ed., Environmental Research Papers 411, Air Force Cambridge Research Laboratories, Bedford, Massachusetts.

McPhee, M.G., Proshutinsky, A., Morison, J.H., Steele, M., Alkire, M.B., 2009. Rapid change in freshwater content of the Arctic Ocean. Geophysical Research Letters 36, L10602. doi:10.1029/ 2009GL037525.

Mork, K.A., Blindheim, J., 2000. Variations in the Atlantic inflow to the Nordic Seas, 1955-1996. Deep-Sea Research Part I 47, 1035-1057.

Nghiem, S.V., Rigor, I.G., Perovich, D.K., Clemente-Colón, P., Weatherly, J.W. Neumann, G., 2007. Rapid reduction of Arctic perennial sea ice. Geophysical Research Letters 34, L19504. doi:10.1029/2007GL031138.

Nicolaus, M., Hudson, S.R., Gerland, S., Munderloh, K., 2010a. A modern concept for autonomous and continuous measurements of spectral albedo and transmittance of sea ice. Cold Regions Science and Technology 62, 14-28.

Nicolaus, M., Gerland, S., Hudson, S.R., Hanson, S., Haapala, J., Perovich, D.K., 2010b. Seasonality of spectral albedo and transmittance as observed in the Arctic Transpolar Drift in 2007. Journal of Geophysical Research - Oceans 115, C11011. doi:10.1029/2009JC006074.

Nilsen, F., Gjevik, B., Schauer, U., 2006. Cooling of the West Spitsbergen current: isopycnal diffusion by topographic vorticity waves. Journal of Geophysical Research 111, C08012. doi:10.1029/2005JC002991.

Nøst, O.A., Isachsen, P.E., 2003. The large-scale time-mean ocean circulation in the Nordic Seas and Arctic Ocean estimated from simplified dynamics. Journal of Marine Research 61, 175-210.

Olli, K., Wexels Riser, C., Wassmann, P., Ratkova, T., Arashkevich, E., Pasternak, A. 2002. Seasonal variation in vertical flux of biogenic matter in the marginal ice zone and the central Barents Sea. Journal of Marine Systems 38, 189-204.

Olsen, S.M., Hansen, B., Quadfasel, D., Østerhus, S., 2008. Observed and modelled stability of overflow across the Greenland-Scotland ridge. Nature 455, 519523.

Orvik, K.A., Skagseth, Ø., Mork, M., 2001. Atlantic inflow to the Nordic Seas: current structure and volume fluxes from moored current meters, VM-ADCP and SeaSoar-CTD observations, 1995-1999. Deep-Sea Research Part I 48, 937-957.

Orvik, K.A., Niiler, P., 2002. Major pathways of Atlantic water in the northern North Atlantic and Nordic Seas toward Arctic. Geophysical Research Letters 29, 1896. doi:10.1029/2002GL015002.

Orvik, K.A., Skagseth, Ø., 2003. The impact of the wind stress curl in the North Atlantic on the Atlantic inflow to the Norwegian Sea toward the Arctic Geophysical Research Letters 30, 1884. doi:10.1029/2003GL017932.

Orvik, K.A., 2004. The deepening of the Atlantic water in the Lofoten Basin of the Norwegian Sea, demonstrated by using an active reduced gravity model. Geophysical Research Letters 31, L01306. doi:10.1029/2003GL018687.

Orvik, K.A., Skagseth, Ø., 2005. Heat flux variations in the eastern Norwegian Atlantic Current toward the Arctic from moored instruments, 1995-2005. Geophysical Research Letters 32, L14610. doi:10.1029/2005GL023487.

Orvik, K.A., Skagseth, Ø., 2010. The connection between the properties of the Norwegian Atlantic Current and the dynamics of the Northern North Atlantic with emphasis on the extraordinary warming 1995-2005. in preparation.

Ourmières, Y., Brankart, J.-M., Berline, L., Brasseur, P., Verron, J., 2006. Incremental analysis update implementation into a sequential ocean data assimilation system. Journal of Atmospheric and Oceanic Technology 23, 1729-1744.

Pasternak, A., Arashkevich, E., Wexels Riser, C., Ratkova, T., Wassmann, P., 2000. Seasonal variation in zooplankton and suspended faecal pellets in the subarctic fjord Balsfjorden, northern Norway, in 1996. Sarsia 85, 439-452.

Pedersen, C.A., Roeckner, E., Lüthje, M., Winther, J.-G, 2009a. A new sea ice albedo scheme including melt ponds for ECHAM5 general circulation model. Journal of Geophysical Research 114, D08101. doi:10.1029/2008JD010440.

Pedersen, C.A., Hall, R., Gerland, S., Sivertsen, A.H., Svenøe, T., Haas, C., 2009b. Combined airborne profiling over Fram Strait sea ice. Fractional sea-ice types, albedo and thickness measurements. Cold Regions Science and Technology 55 23-32. doi:10.1016/j.coldregions.2008.08.004.

Pedlosky, J., 1969. Linear theory of the circulation of a stratified ocean. Journal of Fluid Mechanics 35, 185-205.

Perovich, D.K., Roesler, C.S., Pegau, W.S., 1998. Variability in Arctic sea ice optical properties. Journal of Geophysical Research 103 (C1), 1193-1208.

Perovich, D.K., Grenfell, T.C., Light, B., Hobbs, P.V., 2002. Seasonal evolution of the albedo of multiyear Arctic sea ice. Journal of Geophysical Research 107 (C10) 8044. doi:10.1029/2000JC000438.

Perovich, D.K., 2005. On the aggregate-scale partitioning of solar radiation in Arctic sea ice during the surface heat budget of the Arctic Ocean (SHEBA) field experiment. Journal of Geophysical Research 110, C03002. doi:10.1029/ 2004JC002512.

Piechura, J., Walczowski, W., 2009. Warming of the west Spitsbergen current and sea ice north of Svalbard. Oceanologia 51, 147-164.

Polyakov, I.V., Beszczynska, A., Carmack, E.C., Dmitrenko, I.A., Fahrbach, E., Frolov, I.E., Gerdes, R., Hansen, E., Holfort, J., Ivanov, V.V., Johnson, M.A., Karcher, M., Kauker, F., Morison, J., Orvik, K.A., Schauer, U., Simmons, H.L., Skagseth, Ø., Sokolov, V.T., Steele, M., Timokhov, L.A., Walsh, D., Walsh, J.E., 2005. One more step toward a warmer Arctic. Geophysical Research Letters 32, L17605. doi:10.1029/2005GL023740. 
Poulain, P.-M., Warn-Varnas, A., Niiler, P.P., 1996. Near-surface circulation of the Nordic seas as measured by Lagrangian drifters. Journal of Geophysical Research 101 (C8), 18237-18258.

Proshutinsky, A., Bourke, R.H., McLaughlin, F.A., 2002. The role of the Beaufort Gyre in Arctic climate variability: seasonal to decadal climate scales. Geophysica Research Letters 29, 2100. doi:10.1029/2002GL015847.

Proshutinsky, A., Krishfield, R., Timmermans, M.-L., Toole, J., Carmack, E. McLaughlin, F., Williams, W.J., Zimmerman, S., Itoh, M., Shimada, K., 2009. Beaufort Gyre freshwater reservoir: state and variability from observations. Journal of Geophysical Research 114, C00A10. doi:10.1029/2008JC005104.

Rabe, B., Schauer, U., Mackensen, A., Karcher, M., Hansen, E., Beszczynska-Möller, A. 2009. Freshwater components and transports in the Fram Strait-recent observations and changes since the late 1990s. Ocean Science 5, 219-233. www.ocean-sci.net/5/219/2009/.

Reigstad, M., Wassmann, P., Wexels Riser, C., Øygarden, S., Rey, F., 2002. Variations in hydrography, nutrients and chlorophyll $a$ in the marginal ice-zone and the central Barents Sea. Journal of Marine Systems 38, 9-29.

Reigstad, M., Carroll, J., Slagstad, D., Ellingsen, I., Wassmann, P., this volume. Intraregional comparison of productivity, carbon flux and ecosystem composition within the northern Barents Sea. Progress in Oceanography,

Ricchiazzi, P., Yang, S., Gautier, C., Sowle, D., 1998. SBDART: a research and teaching software tool for plane-parallel radiative transfer in the Earth's atmosphere. Bulletin of the American Meteorological Society 79, 2101-2114. doi:10.1175/ 1520-0477(1998)079\&lt;2101:SARATS $>2.0 . C O ; 2$.

Richter, K., Furevik, T., Orvik, K.A., 2009. Effect of wintertime low-pressure systems on the Atlantic inflow to the Nordic seas. Journal of Geophysical Research 114 C09006. doi:10.1029/2009JC005392.

Rossby, T., Prater, M.D., Søiland, H., 2009. Pathways of inflow and dispersion of warm waters in the Nordic seas. Geophysical Research Letters 114, C04011. doi:10.1029/2008JC005073.

Rudels, B., Fahrbach, E., Meincke, J., Budéus, G., Eriksson, P., 2002. The East Greenland Current and its contribution to the Denmark Strait overflow. ICES Journal of Marine Science 59, 1133-1154.

Sakshaug, E., 2004. Primary and secondary production in the Arctic seas. In: Stein, R., Macdonald, R.W. (Eds.), The Organic Carbon Cycle in the Arctic Ocean. Springer-Verlag, Berlin Heidelberg, pp. 57-81.

Salmon, R., 1986. A simplified linear ocean circulation theory. Journal of Marine Research 44, 695-711.

Schauer, U., Beszczynska-Möller, A., Walczowski, W., Fahrbach, E., Piechura, J., Hansen, E., 2008. Variation of measured heat flow through the Fram Strait between 1997 and 2006. In: Dickson, R.R., Meincke, J., Rhines, P. (Eds.), ArcticSubarctic Ocean Fluxes: Defining the Role of the Northern Seas in Climate. Springer, Dordrecht, pp. 65-86.

Serreze, M.C., Barrett, A.P., Slater, A.G., Woodgate, R.A., Aagaard, K., Lammers, R.B. Steele, M., Moritz, R., Meredith, M., Lee, C.M., 2006. The large-scale freshwater cycle of the Arctic. Journal of Geophysical Research 111, C11010. doi:10.1029/ 2005JC003424.

Shimada, K., Kamoshida, T., Itoh, M., Nishino, S., Carmack, E., McLaughlin, F., Zimmermann, S., Proshutinsky, A., 2006. Pacific Ocean inflow: influence on catastrophic reduction of sea ice cover in the Arctic Ocean. Geophysical Research Letters 33, L08605. doi:10.1029/2005GL025624.

Skagseth, Ø., Orvik, K.A., Furevik, T., 2004. Coherent variability of the Norwegian Atlantic slope current derived from TOPEX/ERS altimeter data. Geophysica Research Letters 31, L14304. doi:10.1029/2004GL020057.

Skagseth, Ø., 2008. Recirculation of Atlantic Water in the western Barents Sea. Geophysical Research Letters 35, L11606. doi:10.1029/2008GL033785.

Skagseth, Ø., Drinkwater, K., Terrile, E., 2011. Wind and buoyancy induced transport of the Norwegian Coastal Current in the Barents Sea. submitted for publication.

Skarðhamar, J., Svendsen, H., 2005. Circulation and shelf - ssocean interaction off North Norway. Continental Shelf Research 25, 1541-1560.

Slagstad, D., McClimans, T.A., 2005. Modeling the ecosystem dynamics of the Barents Sea including the marginal ice zone. Journal of Marine Systems 58, 118.

Smedsrud, L.H., Ingvaldsen, R., Nilsen, J.E.Ø., Skagseth, Ø., 2010. Heat in the Barents Sea: transport, storage, and surface fluxes. Ocean Science 6, 219-234.
Søiland, H., Prater, M.D., Rossby, T., 2008. Rigid topographic control of currents in the Nordic Seas. Geophysical Research Letters 35, L18607. doi:10.1029/ 2008 GL034846.

Spall, M.A., 2005. Buoyancy-forced circulations in shallow marginal seas. Journal of Marine Research 63, 729-752.

Stamnes, K., Tsay, S.-C., Wiscombe, W., Jayaweera, K., 1988. Numerically stable algorithm for discrete-ordinate-method radiative transfer in multiple scattering and emitting layered media. Applied Optics 27, 2502-2509.

Stouffer, R.J., Yin, J., Gregory, J.M., Dixon, K.W., Spelman, M.J., Hurlin, W., Weaver, A.J., Eby, M., Flato, G.M., Hasumi, H., Hu, A., Jungclaus, J.H., Kamenkovich, I.V., Levermann, A., Montoya, M., Murakami, S., Nawrath, S., Oka, A., Peltier, W.R., Robitaille, D.Y., Sokolov, A., Vettoretti, G., Weber, S.L., 2006. Investigating the causes of the response of the thermohaline circulation to past and future climate changes. Journal of Climate 19, 1365-1387.

Stroeve, J., Holland, M.M., Meier, W., Scambos, T., Serreze, M., 2007. Arctic sea ice decline: faster than forecast. Geophysical Research Letters 34, L09501. doi:10.1029/2007GL029703.

Teigen, S.H., Nilsen, F., Gjevik, B., 2010. Barotropic Instability in the West Spitsbergen Current. Journal of Geophysical Research 115, C07016. doi:10.1029/2009JC005996.

Tremblay, J.-É., Simpson, K., Martin, J., Miller, L., Gratton, Y., Barber, D., Price, N.M., 2008. Vertical stability and the annual dynamics of nutrients and chlorophyll fluorescence in the coastal, southeast Beaufort Sea. Journal of Geophysical Research 113, C07S90.

Uppala, S.M., Kållberg, P.W., Simmons, A.J., Andrae, U., da Costa Bechtold, V., Fiorino, M., Gibson, J.K., Haseler, J., Hernandez, A. Kelly, G.A. Li, X, Onogi, K., Saarinen, S., Sokka, N., Allan, R.P., Andersson, E., Arpe, K., Balmaseda, M.A., Beljaars, A.C.M., van de Berg, L., Bidlot, J., Bormann, N., Caires, S., Chevallier, F., Dethof, A., Dragosavac, M., Fisher, M., Fuentes, M., Hagemann, S., Hólm, E., Hoskins, B.J., Isaksen, L., Janssen, P.A.E.M. Jenne, R., McNally, A.P., Mahfouf, J-F., Morcrette, J.J., Rayner, N.A., Saunders, R.W., Simon, P., Sterl, A., Trenberth, K.E., Untch, A., Vasiljevic, D., Viterbo, P., Woollen, J., 2005. The ERA-40 re-analysis. Quarterly Journal of the Royal Meteorological Society 131, 2961-3012.

Vihma, T., Jaagus, J., Jakobson, E., Palo, T., 2008. Meteorological conditions in the Arctic Ocean in spring and summer 2007 as recorded on the drifting ice station Tara. Geophysical Research Letters 35, L18706. doi:10.1029/2008GL034681.

Walczowski, W., Piechura, J., 2007. Pathways of the Greenland Sea warming. Geophysical Research Letters 34, L10608. doi:10.1029/2007GL029974.

Wang, M., Overland, J.E., 2009. A sea ice free summer Arctic within 30 years? Geophysical Research Letters 36, L07502. doi:10.1029/2009GL037820.

Warren, S.G., Rigor, I.G., Untersteiner, N., Radionov, V.F., Bryazgin, N.N., Aleksandrov, Y.I., Colony, R., 1999. Snow depth on Arctic Sea ice. Journal of Climate 12, 1814-1829.

Wassmann, P., Bauerfeind, E., Fortier, M., Fukuchi, M., Hargrave, B., Moran, B., Noji, T., Nöthig, E.-M., Olli, K., Peinert, R., Sasaki, H., Shevchenko, V., 2004. Particulate organic carbon flux to the Arctic Ocean Sea floor. In: Stein, R., Macdonald, R.W. (Eds.), The Organic Carbon Cycle in the Arctic Ocean. Springer-Verlag, Berlin Heidelberg, pp. 101-138.

Wassmann, P., Slagstad, D., Wexels Riser, C., Reigstad, M., 2006. Modelling the ecosystem dynamics of Barents Sea including the marginal ice zone. II. Carbon flux and interannual variability. Journal of Marine Systems 59, 1-24.

Wiscombe, W.J., Warren, S.G., 1980. A model for the spectral albedo of snow. I: pure snow. Journal of Atmospheric Sciences 37, 2712-2733. doi:10.1175/15200469(1980)037\&lt;2712:AMFTSA>2.0.CO;2.

Woodgate, R.A., Weingartner, T., Lindsay, R., 2010. The 2007 Bering Strait oceanic heat flux and anomalous Arctic sea-ice retreat. Geophysical Research Letters 37, L01602. doi:10.1029/2009GL041621.

Worthington, L.V., 1969. An attempt to measure the volume transport of the Norwegian Sea overflow water through the Denmark Strait. Deep-Sea Research $16,421-432$.

Wunsch, C., 2002. What is the thermohaline circulation? Science 298, 1179-1181. doi:10.1126/science.1079329.

Zhang, J., Rothrock, D.A., Steele, M., 1998. Warming of the Arctic Ocean by a strengthened Atlantic inflow: model results. Geophysical Research Letters 25, 1745-1748. 